\title{
ELECTROFISHING SURVEY OF THE GREAT MIAMI RIVER SEPTEMBER 1994 \\ ANNUAL REPORT
}

by

Lane E. Stocker Michael C. Miller

Rebecca L. Evans

Richard W. Koch

Department of Biological Science

University of Cincinnati, ML 0006

Cincinnati, Ohio 45221

(513) $556-9751$

January 1995

PREPARED FOR THE

FERNALD ENVIRONMENTAL MANAGEMENT PROJECT FERNALD ENVIRONMENTAL RESTORATION MANAGEMENT CORPORATION

P.O. BOX 538704

CINCINNATI, OHIO 45253-8704

Under Contract DE-AC05-92OR21972

U.S. Department of Energy FERNALD FIELD OFFICE 


\section{NOTICE}

This report was prepared as an account of work sponsored by an agency of the United States government. Reference herein to any specific commercial product, process, or service by trade name, trademark, manufacturer, or otherwise does not constitute or imply its endorsement, recommendation, or favoring by the United States government or any agency thereof. The views and opinions of authors expressed herein do not necessarily state or reflect those of the United States government, or any agency thereof or Fernald Environmental Restoration Management Corporation, its affiliates or its parent companies.

\section{DISCLAIMER}

This report was prepared as an account of work sponsored by an agency of the United States Government. Neither the United States Government nor any agency thereof, nor any of their employees, makes any warranty, express or implied, or assumes any legal liability or responsibility for the accuracy, completeness, or usefulness of any information, apparatus, product, or process disclosed, or represents that its use would not infringe privately owned rights. Reference herein to any specific commercial product, process, or service by trade name, trademark, manufacturer, or otherwise does not necessarily constitute or imply its endorsement, recommendation, or favoring by the United States Government or any agency thereof. The views and opinions of authors expressed herein do not necessarily state or reflect those of the United States Government or any agency thereof.

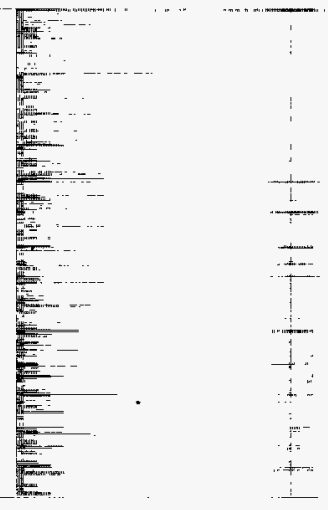




\section{DISCLAIMER}

Portions of this document may be illegible in electronic image products. Images are produced from the best available original document. 


\section{TABLE OF CONTENTS}

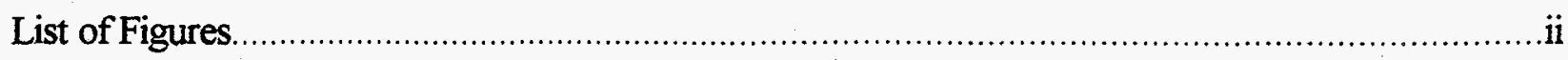

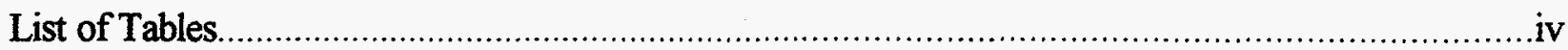

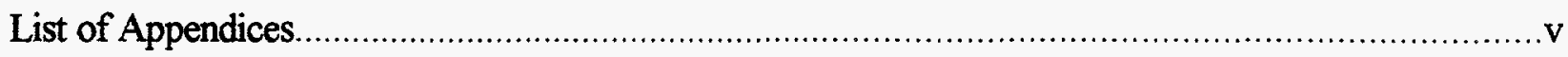

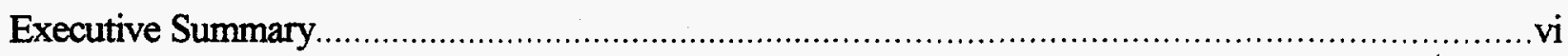



Methods

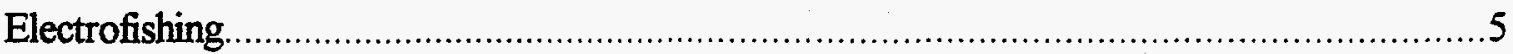

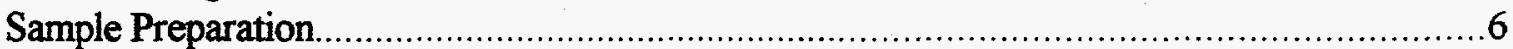



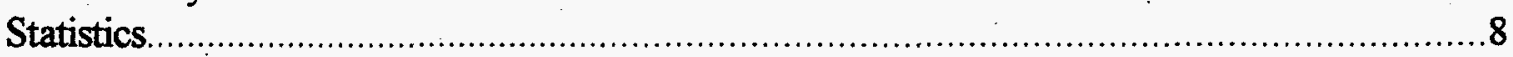

Site Description

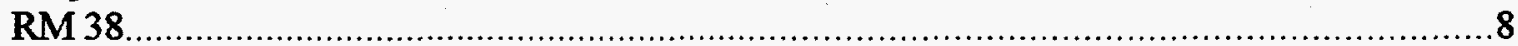



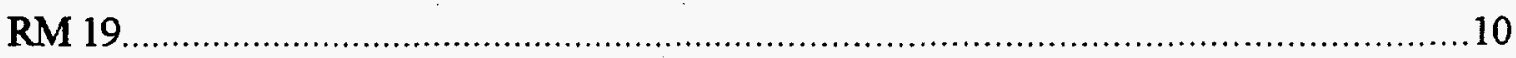

Results and Discussion

Physical, Chemical Parameters

Site Comparisons...



Fish Parameters

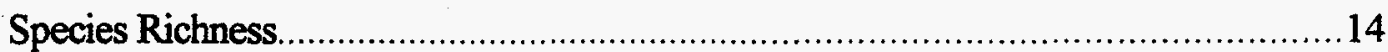

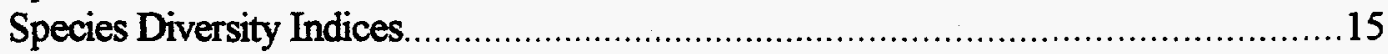

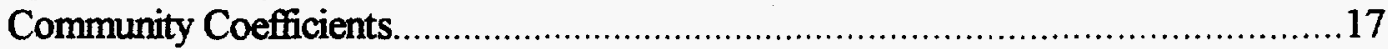



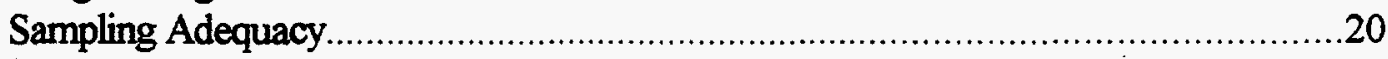

Ordination by Detrended Correspondence Analysis..........................................20

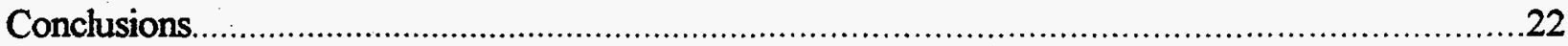

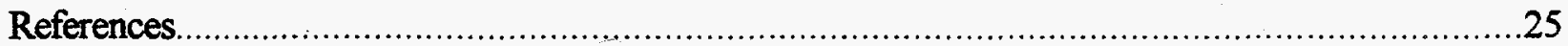

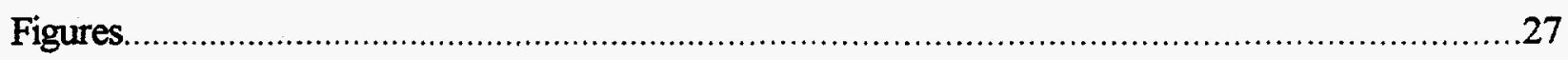










\section{LIST OF FIGURES}

Figure 1. Overview map of the sampling sites in the Great Miami River, 1994........27

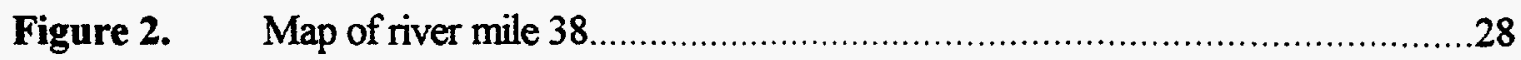



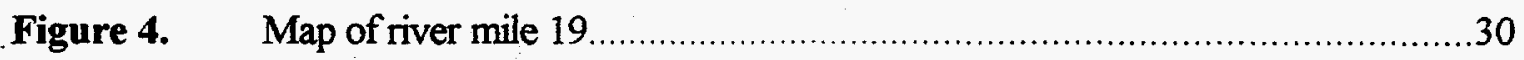

Figure 5. Index of Biotic Integrity, Index of Well Being, and Index of Habitat Quality in the Great Miami River from the Ohio River (RM 0) to Dayton (RM 50) from OEPA data, 1980, 1987, 1989

Figure 6. Phosphorus, nitrate, and ammonia concentrations found at each site in the Great Miami River, 1994.

Figure 7. Sulfate concentrations and conductivity levels found at each site in the Great Miami River, 1994

Figure 8. Levels of $\mathrm{pH}$ and oxygen concentrations found at each site in the Great Miami River, 1994.

Figure 9. Inorganic nitrogen to phosphorus ratio, by weight, for each site in the Great Miami River, 1994.

Figure 10. The number of species and the number of fish per site in the Great Miami River, 1994.

Figure 11. The number of fish species in four subsamples at three river sites in the Great Miami River, 1994.

Figure 12. The number of fish caught per hour and the number of fish caught per kilometer in the Great Miami River. 1994.

Figure 13. The total weight and the biomass per hour of fish captured at each site in the Great Miami River, 1994

Figure 14. Shannon Diversity Index of fish captured in the Great Miami River, 1994. 
Figure 15. The cumulative proportion of fish by weight captured in the Great Miami River, 1994.

Figure 16. The cumulative proportion of fish by length captured in the Great Miami River, 1994

Figure 17. Length/weight relationship for gizzard shad in the Great Miami River, 1994

Figure 18. Length/weight relationship for striped and smallmouth bass in the Great Miami River, 1994.

Figure 19. Length/weight relationship for sunfish in the Great Miami River, 1994

Figure 20. Length/weight relationship for freshwater drum in the Great Miami River, 1994.

Figure 21. Length/weight relationship for carp in the Great Miami River, 1994.

Figure 22. Length/weight relationship for Catostomidae in the Great Miami River, 1994

Figure 23. The cumulative number of fish species per number of fish at each river site in the Great Miami River.

Figure 24. Detrended Correspondence Analysis of sites using fish species composition in the Great Miami River, 1994. 


\section{LIST OF TABLES}

Table 1. Biotic and drainage data from Ohio EPA for the Great Miami River for reference sites for comparison of other sites in the drainage area (data 1980 to 1986).

Table 2. Physical and chemical parameters for all sites sampled in the Great Miami River, 1994.

Table 3. Common name, family, and numbers of fish collected by site in the Great Miami River, 25 and 26 September, 1994

Table 4. Analysis of subsamples at each of the site locations in the Great Miami River, 1994

Table 5. The number of fish captured per hour and the number of species captured by river mile and by year from the Great Miami River, 1984 to 1994. 55

Table 6. Mean weight and length of fish electroshocked by year and by river mile in the Great Miami River, 1984 to 1994.

Table 7. Species diversity and evenness using the Shannon Information Index (Hbar (log base 2)) by year and by river mile in the Great Miami River, 1984 to 1994

Table 8. Community coefficients of species similarity between sites in the Great Miami River, 1994.

Table 9. Weight frequency distribution of fish electroshocked in the Great Miami River, 25 and 26 September, 1994.

Table 10. Length frequency distribution of fish electroshocked in the Great Miami River, 25 and 26 September, 1994 


\section{LIST OF APPENDICES}

Appendix A. Listing of common names, species, and families in the Great Miami River, 1994.

Appendix B. Listing of the lengths and weights of fish captured at River Mile 38, 1994 ...60

Appendix C. Listing of the lengths and weights of fish captured at River Mile 24, 1994 ...66

Appendix D. Listing of the lengths and weights of fish captured at River Mile 19, 1994_...71 


\section{EXECUTIVE SUMMARY}

Fish sampling by electroshocking in the Great Miami River upstream and downstream the Fernald site (September 25 and 26, 1994) was designed to determine changes in the health of the fish community compared to the previous ten years and to collect samples for uranium analyses in fish filets. Samples of 853 fish, from 27 species, eight families and three sites at river mile (RM) 38, RM 24 , and RM 19 provided seventy-eight samples for uranium analyses by an independent laboratory. The biomass of fish caught per hour was greatest at RM $24>\mathrm{RM} 19>\mathrm{RM} 38$. The diversity index and the heaviest fish community was RM $24>\mathrm{RM} 38>\mathrm{RM} 19$. The pooled site at RM 38 near Hamilton was diagnostically separated from the other sites by the young-of-the-year (YOY) golden redhorse, smallmouth bass and golden shiner. The dams at Hamilton acted as an effective barrier against fish migration upriver. Larger freshwater drum, gizzard shad, channel catfish and flathead catfish, which might be expected in rapid current reaches of mid-sized rivers characterize RM 24 . The pool at RM 19 was distinguished from the others by YOY gizzard shad, bluegill, and longear sunfish. Thus the fish community in 1994 was separated ecologically by the physical features of the habitat more than by water quality differences between sites. These data suggest that the Fernald effluents in September were having no detectable effects on the distribution of fishes, independent of changes in habitat quality separated on physical attributes of the river channel at each site.

Compared to previous years, the number of fish captured per unit effort was much higher. This could be a result of the low river flow in conjunction with new electroshocking equipment. Even with the higher densities, the fish captured tended to be heavier fish than average for previous years. Normally when fish densities are increased there is a compensatory decrease in growth rates of the residents. Shannon diversity was not significantly different between sites or between years. 
Water samples were taken at RM 38, RM 24, RM 19, and three additional sites (RM 42, RM 27, and RM 12) in order to help demonstrate downstream trends. Physical and chemical parameters for each site were observed. All parameters tested showed typical downstream trends. $\mathrm{PO}_{4}, \mathrm{NO}_{3}$, $\mathrm{NH}_{4}$ levels and secchi depth decreased downstream while $\mathrm{pH}, \mathrm{SO}_{4}$, and total chlorophyll levels increased. All sites had supersaturated levels of dissolved oxygen except for RM 24. The supersaturated oxygen could have been bubbled off in the riffles. Water temperature increased with the time of day.

The fish community in 1994 was healthy at all sites, reflecting changes in the physical habitat and not changes in water quality. This type of fish community, characterized by high species diversity and high individual numbers, is what is expected in a clean river. 


\section{INTRODUCTION}

Each August or September from 1984 to the present, the status of the Great Miami River (GMR) fishery has been examined at three or four sites as part of a survey of uranium content of fish fillets (1984-1990, 1993 and 1994) and whole fish (1991 and 1992) (Figures 1-4). The fish community in the river had been studied only sporadically before 1980 , when the Ohio Environmental Protection Agency (OEPA) began surveying the streams, rivers, and lakes in Ohio to determine compliance with clean water standards. The surveying effort necessitated the development of a new set of indices and standardized sampling methods for fish and macroinvertebrates (OEPA, 1988). Since multiple sites have been monitored annually for an extended number of years using similar methods and sample sizes, comparison to OEPA's surveys $(1980,1987$, and 1990) over the length of the river is warranted (Rankin et al., 1990). Moreover, the OEPA established a series of high quality reference streams in the state by ecoregion, province of similar soils, bedrock, morphometry, and drainage that allows comparison of biological health between equal-sized bodies of water courses.

The fish communities of the GMR near the Fernald site are affected by the Ohio River as well as upstream processes. The Ohio River and the many tributary streams of the GMR serve as a source and a refugium for biotic diversity. Between 1957 and 1959, fish sampling in the middle Ohio River identified 83 species of fish in lock and dam rotenone studies conducted in the fall (Pearson and Krumholz, 1984; Krumholz, 1981). Additional studies on Ohio River tributaries have found more species. An ORSANCO study (Ohio River Valley Water Sanitation Commission, 1962) found 108 species of fish in the Ohio River and by 1970 the cumulative species list of the fish for the Ohio River (a total of 983 river miles) was 120 . Between 1974 and 1986, an average of 22 species of fish were found in single day samples from the GMR ( $\mathrm{n}=2,100$ to 3,700 individuals). Hence, approximately one 
fifth of the cumulative fish species can be found in a single day's sample. The remaining species are globally rare, restricted to unique micro-habitats, associated with tributary streams, accidentally washed-in from reservoirs, or only temporal residents of the river. The diversity in middle-sized rivers is determined in part by migration of fish species such as the white bass, sauger, mooneye, hybrid striped bass, gizzard shad, and carp from big rivers. It is also determined in part by migration of smaller stream species into larger rivers, such as minnows, darters, northern hognose suckers, and white suckers. Mid-sized rivers have a high diversity of lithophils belonging to true river fish species, the suckers, buffalos, carpsuckers, redhorses (Catostomidae), and catfishes (Ictaluridae). Washout from upstream reservoirs and ponds may contribute species of fish such as largemouth bass, sunfishes, and young-of-the-year (YOY) gizzard shad.

The diversity of fish in a given reach of stream is a function of the water quality (chemical variables), size of the stream, habitat structure (riparian zone), energy base (allochthonous or autochthonous), flow regime (riffle or pool), and biotic interactions (competition and predation risk) (Karr, 1981; Karr et al., 1986). The OEPA has coded a system of assessing habitat quality. Their Quality Habitat Environmental Index (QHEI) includes current velocity, bank stability, canopy, riparian vegetation, in-stream cover, gradient, channel morphology, channel width, and channel depth (OEPA, 1988). The standardization of electroshocking methods and the use of multicomponent indices, such as the Index of Biotic Integrity (IBI) and the Index of Well-Being (Iwb) (Gammon, 1976b), has allowed the OEPA to characterize the water quality of the GMR and its tributary streams over the past decade (OEPA, 1990).

The GMR is a multi-stressed river receiving significant industrial and domestic sewage pollution from sites near Dayton, OH (Yoder et al., 1976; Beckett, 1978, 1977; Moller, 1986). Rankin et al. (1990) summarized the factors that degrade Ohio's running waters. These factors 
include municipal and industrial point sources and agricultural and non-point sources. Municipal and industrial point sources affect the most river miles. Non-point sources, such as agriculture, can cause channelization and siltation which lead to habitat modification. These are the two most serious contributors to non-point habitat impairment.

The GMR headwaters have exceptional water quality as assessed by the multicomponent indices for fish and macroinvertebrates called the Index of Community Integrity (ICI). Headwater reference sites have 19-21 species and clean tributaries have 17 to 30 species of fish samples in a single day (Table 1).

Upstream of the Fernald site, major sources of pollutants exist that may affect the biological water quality downriver. These include the cities of Dayton (RM 50) and Hamilton (RM 38). Toxins, excess nutrients, sewage, bacteria, and thermal enrichments are contaminants generated by urban and industrial centers. Sites below Dayton have shown IBI, Iwb, and ICI values in the poor to very poor range between 1985 and 1989 (Rankin et al., 1990). The concentrations of all pollutants appear to drop in the area of the river near the Fernald site. This could be due to the enforcement of water pollution laws and the construction of sewage plants along the GMR. However, low-flow pollution loading and elevated temperatures have combined to cause large fish kills. During the 1988 drought, approximately 261,000 fish were enumerated in a major kill caused by high temperatures near Hamilton (Rankin et al., 1990).

IBI results, used by the Ohio Department of Natural Resources (ODNR) for fish communities, range from 20 (poor or degraded) to 40 (good) for various sample sites from the Ohio River to Dayton. Between 1980 and 1989, no site between RM 19 and RM 38 reached an IBI of greater than 33 (fair to moderate impact) (Rankin et al., 1990). The Iwb is a composite index of numbers and weights calculated as Shannon Indices. The modified Iwb ranges from 7.7 to 8.1 in the Fernald site 
reach in 1989 on a scale of 1 to 10 , ten being the best (OEPA, 1990). The ICI ranged from 40 to 50 in the area of Fernald site; classified as good or enriched to exceptional (OEPA, 1988). Only at Hamilton and Dayton does the ICI show degradation to the fair or impacted level. The habitat quality of the GMR is the most variable, QHEI of 50-80, between RM 19 and RM 38 (OEPA, 1988). The lowest quality of habitat was found in Hamilton (Fig. 2). Thus the extensive surveys of the OEPA and ODNR over the past decade show an enriched or degraded river in the area of the Fernald site, improving from point source degradation upriver.

This report emphasizes the comparison among the years, sites, and subsamples on the status of the fishery in terms of numbers, health, species richness, and diversity. With the eleven year database, changes or trends in the status of the river biota can be followed. If abnormal changes occurred at a given site or year, they may be apparent as deviations of species composition or evenness, changes in mean or modal length and weight, and/or changes in condition as observed in length-weight distributions among sites.

Fish samples were collected and fillets were analyzed for uranium content (versus whole and filleted fish in 1991 and 1992). They were shipped as per instructions by the Fernald Environmental Restoration Management Corporation to an independent contract laboratory. The fisheries analysis contained in this report focuses on the areas that are upstream of the Fernald site's effluent line, near the effluent line, and downstream of the effluent line potentially impacted by the Fernald site effluents. Hence, the survey of fish community status and fish radionuclide concentrations around the Fernald site attempts to detect a continuum of improving water quality downriver from Dayton and Hamilton, where dams and channel modification by gravel dredging have severely changed the physical habitat and migration probabilities of fish. 


\section{METHODS}

Electrofishing: Pulsed DC electrofishing is among the most efficient method of collecting relatively unbiased samples with respect to fish size and species, especially in shallow, turbid waters (Gammon, 1976). Fish were electroshocked with a 5.0 GPP portable electrofisher (Smith-Root, Inc., Vancouver, WA) from a five meter flat-bottom boat. A DC current at 60 cycles per second was used. The anodes are located at the end of a two meter boom, one at each front corner of the boat. The anodes themselves are umbrella-shaped with four vertical cables extending 30 centimeters beneath the surface of the water. The cathode is the boat. The electroshocking transformer is powered by a gasoline-driven, 9 horsepower, Briggs and Stratton generator, delivering 5,000-watts of 120-volt $\mathrm{AC}$ at 16 amperes. The shocker delivers approximately 4 to 8 amperes (at 500 to 1000 volts), depending on the conductivity of the water. The system is similar to the type 'A' rig specified by the OEPA in routine boat electrofishing (OEPA , 1988; WQPA-SWS-3, 30 Sept. 1989). Two people, standing behind a railing on the bow of the boat, catch fish with long-handled ( $3 \mathrm{~m}$ ) dip nets. The netters control the electroshocker with a foot-operated "dead-man" switch. The fish lose their equilibrium momentarily in the small area of electrical field near the anode, allowing them to be netted. Thus, the effective area and depth for stunning fish may depend on the species and their size. Large fish are reported to be the most sensitive to the electric field. Almost all fish recover within five minutes in an aerated central well (Viber. 1967) Some of the larger game fish (largemouth bass, smallmouth bass, and striped bass) greater than fifteen centimeters were identified, measured, and released immediately after gill motion and equlibrium appeared normal, as specified in our State of Ohio Scientific Collecting Permit. No endangered species were captured.

At each site, four subsamples were taken (approximately 10 minutes each) to compare fish numbers, biomass, and species composition in the subsamples within each site's reach. The 
subsamples were not intended to be replicates of habitat, but to examine variability in spatial sections of each site's reach and to develop a cumulative species list by site. The cumulative number of species for each site was intended to determine if the total sample was large enough to contain most of the species at that particular site. All samples were collected in accordance with Fernald site quality assurance plan (SSOP-0036).

Sample Preparation: The fish collected for uranium analysis and biological survey were placed in plastic bags identified by subsample number, combined by site in a larger bag, immediately placed in a cooler on ice, and the coolers were locked and sealed in the field. The sealed coolers containing the fish were then brought back to a radionuclide-free laboratory at the University of Cincinnati for identification and processing. For each subsample, the fish were identified to species, weighed, and measured (Clay, 1975; Pflieger 1975; Smith, 1979; Trautman, 1981; Boschung et al., 1983; Page and Burr, 1991). Any external abnormalities, such as fin rot, diseases, or fungus were noted. The fish were decapitated, eviscerated, and fins removed to make modified fillets. Some scales, skin, and bones remained with the fillets. These modified fillets are approximately what people would consume if they ate fish from the GMR. The modified fillets from each species or trophic grouping (planktivore, insectivore, piscivore, and benthivore) were adjusted to a wet weight of at least 200 grams, labeled sequentially within each site by species and/or trophic group, and sealed into resealable plastic bags. Fish from each collection site were processed as a group. After processing one group, the area was cleaned so that contamination between groups would not occur. The upstream or control site was processed first in order to minimize any possible cross contamination of uranium from the Fernald site. Any fish that was deemed too small for the uranium analysis was discarded and incinerated at the University of Cincinnati or preserved for the 
University's private fish collection. Any waste from the fish preparation was also incinerated at the University of Cincinnati.

Water Analysis: Water analysis was performed both in the field and at the University of Cincinnati laboratory. Conductivity (microSiemens $/ \mathrm{cm}^{2}$ ) was measured in the lab using a YSI Model 31 conductivity meter and platinum electrode (Yellow Springs Instruments Co., Yellow Springs, $\mathrm{OH}$ ). Dissolved oxygen (ppm $\mathrm{O}_{2}$ at $0.25 \mathrm{~m}$ ) and temperature $\left({ }^{\circ} \mathrm{C}\right)$ were measured in the field using a YSI Model 57 meter (Yellow Springs Instruments Co., Yellow Springs, OH). The turbidity was measured in the field using a secchi disk $(\mathrm{m})$ and standard measuring techniques. The $\mathrm{pH}$ was measured electrometrically using a Cole-Parmer Model 5985-80 digi-sense $\mathrm{pH}$ meter (Cole-Parmer Instrument Co., Chicago, II) standardized by a pH 7 and $\mathrm{pH} 10$ standard buffer. Suspended chlorophyll was separated by filtration on glass-fiber filters, extracted in $10 \mathrm{ml}$ of $90 \%$ acetone for 48 hours at $4^{\circ} \mathrm{C}$ in darkness (Wetzel and Likens 1991), and analyzed spectrometrically. Soluble reactive phosphate was determined colorimetrically by absorbance of phosphomolybdate at $890 \mathrm{~nm}$ in filtrate using the HACH methods (method 490) and the HACH DR/2000 spectrophotometer (HACH, Inc., Loveland, Colorado). Ammonia concentrations were determined colorimetrically by absorbance of salicylate/cyanurate (method 385). Nitrate concentrations were measured by cadmium reduction to nitrite (method 355). Sulfate concentrations were determined colorimetrically by absorbance (method 680). The ammonia, nitrate, and sulfate measurements also used the HACH DR/2000 spectrophotometer (HACH, Inc, Loveland, Colorado). These measurements were designed to discern effects of eutrophication and algal growth, sewage enrichment, and gravel mining activities on the water quality at our sites.

Additional water samples were collected from RM 42, RM 27, and RM 12 in an effort to better document the downstream gradient trends previously found in past studies. These additional 
samples were collected on the same day as the other water samples, 25 September, 1994. These water samples were analyzed in the same manner and using the same equipment as were $R M 38, R M$ 24, and RM 19.

Statistics: Statistical analysis was performed using the statistical package SYSTAT 5.03 for DOS. Multiple pairwise comparisons were performed using Tukey Honestly Significant Difference (HSD) post $F$ test. All statistically significant results have $p \leq 0.05$ (two tailed). One way ANOVAs were used to examine the effect of location and year on parameters of fish community structure. Since the sites were far enough apart and the same fish were not likely to be in the same river location in the next year, ANOVA with years as repeated measures was not needed.

\section{SITE DESCRIPTION}

Three sites on the GMR were used for electrofishing in 1994 (Fig. 1). Two of these sites have been sampled annually at the same time of year since 1984 (RM 24 and RM 19) (Figs. 3 and 4). A third site was added upstream in 1991 as an additional control at RM 38 (Fig. 2). This added site at RM 38 is isolated from the downstream sites by two dams. The site was purposefully chosen in an effort to prevent migration of fish upstream from the RM 24 area. The dams serve as an effective barrier to fish migration except during periods of high water flow.

RM 38 is located at the confluence of Talawanda Creek and the GMR, in Hamilton (Fig. 2). The riparian community is relatively undisturbed, and the habitat provided by fallen trees, rocky shoals, and pools increases habitat heterogeneity. The site is located just upriver of the outlet of Seven Mile Creek up to and around bridge abutments of the US Route 127 bridge. A 490 meter reach of the river was sampled in four 10 minute subsamples. The first subsample began on the east side of the river, starting directly across from the boat ramp, approximately 100 meters above the dam. The sampling started downstream of the boat ramp for 60 meters, continuing across the river 
for 35 meters and upstream along the west shore for another 15 meters. The second subsample was taken along the west side of the river, starting about 500 meters above the dam, and extending upstream 120 meters along the west side of the GMR. The third subsample began 52 meters downstream of the Talawanda Creek on the west side of the river. The subsample proceeded upstream to the creek, 52 meters along the south shore of the creek, across the creek and 26 meters downstream on the north shore of the creek. The fourth subsample began at the mouth of the Talawanda Creek on the west shore of the GMR and continued upstream for 110 meters.

RM 24 is near Stricker's Grove Park and the Fernald site's effluent line (Fig. 3). The mixing zone is a deep, fast section of river with strong eddy currents just below the effluent line. This site is on the outside of a long curve on the western shore. It is steep-sided with a fairly rapid current, the fastest of the survey sites. Some riparian trees, both standing and fallen, provide good cover and high fish species diversity on the east side. The average pool depth here is 1.8 meters. A 770 meter section of the river around the effluent line was sampled. The sampling was divided into four subsamples each lasting 10 minutes. The first subsample of 160 meters began just below the effluent pipe and continued upstream for 80 meters. Sampling continued across the river and down the east shore. The second subsample was taken from the effluent pipe and continued downriver, through a riflle, for approximately 50 meters. Both sides of the river were sampled and some of the area was covered a second time for a total subsampling length of 180 meters. The third subsample began just below the riffle and continued downstream for 50 meters. The entire area of the river, both shores, was covered twice for a total length of 200 meters. The fourth subsample began approximately 200 meters upstream from the effluent pipe and continued upstream for 115 meters. Both shores of the river were sampled. The west side had a steeply banked and wooded shoreline, but the east side had a flat, gravel shoreline. 
RM 19 is found at the outfall of Paddys Run, which is the historic drainage route of stormwater runoff from the Fernald site (Fig. 4). A pool has been created here by 25 years of dredging by a gravel company. The western shore, unaffected by the dragline operations, contains many large boulders and submerged logs, and has good riparian vegetation which provides excellent cover for young fish and structure for adult fish. The eastern shore is steep gravel without vegetation and is unattractive to most fish. The average pool depth is about 2 meters. This site has the slowest current and is pond-like in many respects. Four subsamples were taken, each approximately 10 minutes in duration with a combined distance of 570 meters. The first subsample started 50 meters downstream of old railroad bridge abutments near Dravo Park and ran downstream for 120 meters. The sampling for the first subsample was restricted to the west shore. The second subsample consisted of 100 meters along the west shore and among the bridge abutments. The third subsample started on the west shore approximately 170 meters below the bridge abutments and continued downstream for 200 more meters. The fourth and final subsample was taken from the eastern shore. There has been no dredging activity along the eastem shore for the past two years. The subsample began approximately 70 meters downstream of the bridge abutments and continued downstream for 150 meters.

Samples were collected at RM 38 on 25 September, 1994 and at RM 24 and RM 19 on 26 September, 1994 (Table 2, Figures 1-4). Each site was sampled for about 40 minutes (RM 38= $40.04 \mathrm{~min}$., RM $24=40.01 \mathrm{~min}$., and RM $19=4000 \mathrm{~min}$.). At each site, four equally timed subsamples were taken, each about 10 minutes in duration.

The total distance electrofished was $049 \mathrm{~km}, 077 \mathrm{~km}$, and $0.57 \mathrm{~km}$ at RM 38, RM 24, and RM 19, respectively. This distance is the number of kilometers of shore traversed, rather than the kilometers of river electrofished. The river was too wide to consider a pass down either side a 
representative sample for all the fish in the whole river. The habitat was different on each side of the river and these differences dictated the necessary distance of shore to be electrofished. Poor habitat required less time to electrofish than good habitat, but the fish yield was higher in the good habitat. This is one explanation for the difference in distance electrofished at each site. RM 38 and RM 19 were pooled sections of river; RM 24 was flowing water primarily in open runs. RM 24 had the best development of riparian zone structure that fish prefer.

Both time and distance have biases in interpretation. Time and volume of water sampled were not biased by the speed of movement. The active stun zone was small $(2 \times 1.5 \times 0.5-1 \mathrm{~m}$ deep $)$ that the volume of water sampled remained nearly constant. The use of fish/kilometer for reporting is more common and it eliminates some of the biases.

\section{RESULTS AND DISCUSSION}

\section{Physical, Chemical Parameters:}

Site Comparisons: Physical and chemical data for the three sites show a slight change in conductivity from RM 38 to RM 19 (Table 2). RM 38 was sampled in the late morning (11:20 a.m.) and RM 24 and RM 19 were sampled in the mid-afternoon (2:30 p.m. and 3:15 p.m., respectively). The slight difference in conductivity could be due to diel variation in production and dissolution carbonates caused by diurnal swings in oxygen (Table 2). High $\mathrm{pH}$, temperature, and low concentrations of free $\mathrm{CO}_{2}$ found in mid-afternoon can reduce the solubility of carbonate/bicarbonate causing precipitation of marl from saturated solutions.

The oxygen concentration was slightly lower at morning sampling sites due to diurnal variation in photosynthesis and respiration of the seston and benthos. Oxygen concentration at RM 38 and RM 19 were supersaturated, but the concentration level at RM 24 was less than saturated. Oxygen could be exhausted to the atmosphere with vigorous mixing at the rapids at RM 24 . 
Soluble reactive $\mathrm{PO}_{4}(\mathrm{SRP})$ concentrations, suspended algal chlorophyll concentrations, ammonia and nitrate concentrations, and secchi depth support the hypothesis of increasing trophy of the river (Table 2). The SRP, normally the limiting nutrient controlling algal biomass, was high with 1.123 to $1.554 \mathrm{mg} \mathrm{PO}_{4}^{-3} /$ liter. The concentration of SRP dropped from upriver to downriver as the $\mathrm{PO}_{4}$ was utilized by algal growth. The concentration of sulfate increased from RM 38 to RM 19 (Table 2). The algal chlorophyll, as a measure of algal biomass, showed the same pattern with an increase downriver (Table 2). The algal chlorophyll concentration was between 44.887 and 56.524 $\mu g$ /iter, equivalent to what might be found in a eutrophic lake (Wetzel, 1983). These levels were higher than the levels found in 1993. Normally, sestonic chlorophyll is a minor portion of river algal biomass, because most is attached to rocks as periphyton or epilithon. Concentrations of $\mathrm{NH}_{4}{ }^{+}$stay relatively constant downstream (Table 2), while $\mathrm{NO}_{3}$ concentrations slightly increase down river (Table 2). Secchi depth decreased very slightly downriver.

Down River Trends: Physical and chemical data for the six sites sampled, RM 42 to RM 12, help to show downstream trends. It is difficult to get a complete picture of river nutrients with three sites. The nutrients $\mathrm{PO}_{4}, \mathrm{NO}_{3}$, and $\mathrm{NH}_{4}$ decline from $\mathrm{RM} 42$ downstream to $\mathrm{RM} 12$ (Fig. 6), as though there was a large point source of nutrients. This source is likely to be domestic and industrial sewage treatment plants south of Dayton. A pattern of decreasing conductivity (Fig. 7) would be further evidence for the addition of and uptake of total salts downstream from a point source. Normally, the conductivity would be expected to increase cumulatively down river as the water resembles groundwater instead of rainwater, as it may have started in headwater streams. Sulfate concentrations, normally generated from weathering of rocks and mineralization of protein, does not show any obvious pattern down river. This evidence suggests that this reach below Hamilton is a 
zone where nutrients from Dayton sewage treatment plant and industry are assimilated into new algal biomass. Hence the nutrients are expected to decline further from the source.

The algal biomass should increase down stream and the oxygen supersaturation should be enhanced (Fig. 8). The chlorophyll as an index of algal biomass in the plankton did increase, but especially at the most ponded sites at RM 38 and RM 19. In response, supersaturated oxygen was in pools and lost to the atmosphere with vigorous mixing at the rapids at RM 24. Oxygen could be a function of time of day, since oxygen supersaturation may develop progressively during the day as photosynthesis proceeds. This pattern was not clear in the 1994 data. Clearly, temperature of the river did appear to increase as the time of day progressed.

The inorganic N:P ratio, by weight, is an index of relative availability to algae. A physiological ratio of $7: 1$ for $N: P$, by weight, is required for healthy growth of algae and higher plants. Both $N$ and $\mathbf{P}$ concentrations decrease down river (Table 2); however, $\mathbf{P}$ droppes further than $\mathbf{N}$. Probably $\mathbf{P}$ disappearance and some $\mathrm{N}$ disappearance is caused by algal growth; however, $\mathrm{NO}_{3}$, which is mobile in interstial water, appears to be resupplied over the reach from groundwater or other sources. In the GMR on 25 September, 1994, the 'best' ratio occurred upriver towards the presumptive source at Dayton. As algal growth proceeds, the less soluble $\mathrm{PO}_{4}$ is differentially retained. $\mathrm{NO}_{3}$ - is freely mobile in interstitial waters and appears to be augmented by the downstream transect since the N:P ratio rises continuously from $13: 1$ to $33: 1$.

In the eutrophic reach of river below Dayton stress associated with diel variation in oxygen or nutrients was not perceived to be a stress on fishery. The differences between the fish communities were related to distance from the Ohio River and habitat characteristics at each site. 


\section{Fish Parameters:}

Species Richness: This year 853 fish (vs. 224 fish in 1993 and 491 fish in 1992), from 27 species (vs. 26 spp. in 1993 and 23 spp. 1992), in eight families, were collected from the three sites in the GMR (Figs. 10 and 11, Table 3). No threaten or endangered species were captured. The most diverse families from the river were the Catostomidae (nine species) and Centrarchidae (five species) (Table 3). The number of different species per site ranged from 15 at RM 38 to 20 species at RM 24. The most numerous species was the gizzard shad (Clupeidae) with 244 individuals, followed by golden redhorse (Catostomidae) with 136 individuals, and longear sunfish (Centrarchidae) with 104 individuals (Table 3). Species diversity appears to be slightly greater than has been observed in the past. RM 24 had the highest number of species ever caught for this study with 20 species.

Statistically, a grouped, one way ANOVA showed that among the years 1984 to 1994, there was a difference in the number of species captured by year $(F=3.540, \mathrm{df}=10,24, \mathrm{p}=0.005 \mathrm{HS})$ (Table 5), but not by location ( $F=0.597, d f=3,31, p=0.622$ NS). A post $F$ comparison by Tukey's HSD shows that the number of species caught in 1994 is significantly different from the number caught in 1990 and 1993. The number of species of fish caught in 1991 is also significantly different from the number caught in 1990. This year's study had the most species collected, on average, per site. Previous to this, the collection years 1985 and 1991 netted the most species The collection years 1990 and 1992 still had the fewest number of species collected.

The sites were electroshocked for 2404, 2401, and 2400 seconds at RM 38, RM 24, and RM 19 respectively (Table 4). The fish diversity and density varies with habitat complexity, including topography of the shore, the depth of the pool, the nature of the current, and the amount of vegetation in and over the water (Gammon et al, 1983; Yoder and Gammon, 1976, OEPA, 1988). In 1994, 422, 300, and 557 fish were collected per hour at RM 38, RM 24 and RM 19, respectively 
(Fig. 12, Tables 4 and 5), compared to 72.5, 35, and 90.2 fish per hour in 1993 and 175, 106, and 305 fish per hour in 1992 (Table 5) from the respective locations (RM 38, RM 24, and RM 19). RM 19 had the greatest number of fish collected and the most fish caught per hour. RM 24 had the fewest fish collected, but it had the most biomass collected per hour of all the sites (Fig. 13). RM 24 had the heaviest average fish, two times heavier than RM 38 and three times that of RM 19, and the longest average length of the three study sites (Table 6). Larger and more mature fish were found at RM 24. It has a swifter current that usually excluded the smaller fish. A grouped, one way analysis of variance using four sites from 1984-1994, found significant differences in the number of fish caught per hour between years $(F=4.898, \mathrm{df}=9,22, \mathrm{p}=0.001 \mathrm{HS})$ (Table 5) However, there was no significant difference found among the number of fish caught between $\operatorname{RM}(38,28,24$, and 19) $(\mathrm{F}=1.575, \mathrm{df}=3,28, \mathrm{p}=0.218)$. This year a larger number of fish were caught per $\mathrm{km}$ and subsample. A post F comparison by Tukey's HSD shows that the number of fish caught per hour in 1994 is significantly different from the number of fish caught per hour for every other year. This could be due to low water flow this year. The low water flow would concentrate fish into a smaller amount of water, making electrofishing more effective. The increase in capture rate could also be a result of the new electrofishing equipment which was used this year for the first time for this study. Even though more fish were caught, the general trend of capture did not change. As usual, more fish were returned per unit effort at RM $19>\mathrm{RM} 38>\mathrm{RM} 24$.

Species Diversity Indices: The diversity of fish at each site was measured by the ShannonWiener ( $\mathrm{H}^{\prime}$ or Hbar) index based on the information theory using log base 2 (Krebs, 1989). This index of diversity is increased by the number of species in a sample and the relative uniformity of the numbers of individuals of each species. Samples with fewer species or one species being very dominant have low calculated diversity $\left(\mathrm{H}^{\prime}\right)$. The maximum diversity (Hmax) that can be attained in 
any sample is fixed by the number of species, assuming equal numbers of individuals in all species collected at the site. Gizzard shad dominated the fish community at RM 19. Their numbers had the greatest effect on reducing the diversity at that site (Tables 3 and 7, Fig. 14). At RM 38, golden redhorse accounted for $39 \%$ of all fish caught. This is a change from a gizzard shad dominated community found in last year's sampling. At RM 24, freshwater drum was the dominant species, the same as last year, accounting for $24.5 \%$ of all fish caught. Gizzard shad, accounting for $20.5 \%$ of fish caught, was a close second. At RM 19, gizzard shad accounted for $52 \%$ of all fish collected; this is a $2 \%$ increase from last year. RM 24 had the highest diversity and the highest evenness $\left(H^{\prime}=\right.$ 2.315, $E=0.773$ ) (Table 7, Fig. 14) and was dominated by gizzard shad and freshwater drum. The eleven year mean for $H^{\prime}$ and evenness shows a trend of RM $38>R M 24>R M 19$ and $R M 24>R M$ $38>$ RM 19, respectively (Table 7). RM 28 was not sampled in 1993 and 1994. Thus, the trend for diversity in 1994 (RM $24>$ RM $38>$ RM 19) differed from the trend of the means (RM 38 > RM 24 $>\mathrm{RM} 28>\mathrm{RM} 19$ ). It is possible that the mean diversity trend is affected by the very low diversity found in 1985, 1990 and 1992 at RM 19.

For the diversity index $\mathrm{Hbar}$, a grouped, one way ANOVA disclosed no significant differences between years $(F=0.803, \mathrm{df}=10,24, \mathrm{p}=0.627 \mathrm{NS})$ or site $(\mathrm{F}=2.183, \mathrm{df}=3,31, \mathrm{p}=0.110 \mathrm{NS})$ in the GMR. On average the index was highest at RM 38, RM 24, RM 28, and RM 19, decreasing in that order. This is the same trend that was apparent in 1993. Amongst the years, Hbar was highest in 1986 and 1985 and lowest in 1992.

The grouped, one-way ANOVA revealed a significant difference in mean evenness between $R M(F=6.951, d f=3,31, p=0.001 \mathrm{HS}) . \quad R M 19$ had significantly lower evenness than $R M 28$ and RM 24 in a post $F$ comparison of means, but RM 19 was not significantly different than RM 38. The eleven-year mean evenness at RM 19 is statistically lower than other locations possibly because of 
the high proportion of gizzard shad present in the large dredged pool at RM 19. The years of highest average evenness were 1986 and 1985, contrasting to the years of lowest evenness in 1991 and 1992. In the past two years, there appears to be no further trend towards lower diversity or evenness.

3. Community Coefficients: Differences in community structure can be seen by comparing the similarity of species composition from the three sites. The community coefficient (CC) is a measure of the proportion of species shared by any two sites. It is calculated as two times the number of shared species (c) divided by the sum of all the species found at the two sites ( $a$ and $b$ )

\section{Community Coefficient $=2 \mathrm{c} / \mathrm{a}+\mathrm{b}$}

$\mathrm{ACC}$ of 1.0 indicates that the two sites have identical species composition, while a $\mathrm{CC}$ of 0.0 means there are no shared species (Krebs 1989). A low CC may reflect differences of habitat due to geographical separation or a pollution gradient.

The CC shows that all three sites $(\mathrm{RM} 38,24$, and 19$)$ are similar $(C C=$ ca. 0.50$)($ Table 8$)$. RM 24 and 19 are more similar $(C C=0.76)$ than are $\mathrm{RM} 38$ and 24 and $\mathrm{RM} 38$ and $19(\mathrm{CC}=0.63$ and 0.50 , respectively). Another way to examine species data at several sites is to observe how many species are found at only one site, two sites, etc.. For 1994, 10 species were found at only one site, 9 are found at two sites, and 8 at all three sites, compared with 15, 5, and 6, respectively, for 1993 (Table 3).

Weight/Length Distributions: The weight and length frequency distributions of fish collected were calculated as percent per size and cumulative percent per size (Tables 9 and 10). The modal weight is observed to be between 25 to 50 grams (g) for fish caught at RM 38, RM 24 and RM 19 (Table 9). Cumulative distribution of proportion of fish by weight shows the effect of size classes 
in composition of the fishery. If the cumulative weight distribution rises quickly, then small fish dominate. This is the form of the distribution found in at RM 38 and RM 19 (Fig. 15), the two most ponded sites. In both of these sites, more than $74 \%$ of the fish accumulated were less than $100 \mathrm{~g}$ in size (Fig. 15). RM 38 had a large number of YOY golden redhorse, longear sunfish and smallmouth bass. RM 19 was dominated by YOY gizzard shad, bluegill and longear sunfish. On the other hand if the cumulative weight distribution curve increases slowly, then the fishery is dominated by larger fish. This is the distribution found at RM 24, with less than $38 \%$ of these fish weighing less than 100 $\mathrm{g}$ (Fig. 15). The large differences in distribution stemmed from the large number of YOY at the two pooled sites, RM 38 and RM 19.

The length frequency distributions (Table 10) show the modal length of fishes at RM 38 (10 to $12 \mathrm{~cm}$ ) was the smallest. RM 24 had the longest modal length $(28$ to $30 \mathrm{~cm}$ ), and a bimodal distribution of fish at sizes from eight to $18 \mathrm{~cm}$ and 24 to $36 \mathrm{~cm}$ (Table 10). RM 19's modal length of the distribution is 12 to $14 \mathrm{~cm}$. The diagram of cumulative proportion of fish by length (Fig. 16) illustrates a gradual rise to the asymptote. In a uniform sized distribution, the curve rises linearly to the asymptote. This graphically shows that there is a slightly even distribution of fish from different length classes, similar to last year; however, there is still a large number of small fish. Clearly RM 38 and RM 19 are dominated by more small fish than any others, with at least $72 \%$ of the fish being less than $20 \mathrm{~cm}$ (Table 10, Fig. 16). RM 24 had the largest and most uniform size frequency with a more linear rise in the cumulative frequency curve. RM 24 has a more even rise in cumulative frequency this year compared to last year. The dramatic rise in the frequency found from 22 to 30 $\mathrm{cm}$, which accounted for $51 \%$ of the fish from RM 24 , is not present. The curve of the cumulative frequency plot can help to describe a site. When skewed to the young of one species, the curves imply enrichment in food or habitat. When uniform and linear, the curves suggests an older 
population, which could mean a uniformly fast current or a condition that has lead to a loss of the more sensitive young fish. The young-biased curves at RM 38 and RM 19 to probably reflect enrichment and pooling that favor gizzard shad and immature fish. The loss of young fishes probably reflect habitat conditions and current, not a toxic stress, at RM 24 .

The changes in growth rate and condition can be examined for common species using (length $\mathrm{x}$ wet weight) distributions. This curve, reflecting allometry of length and weight, deviations in weight per unit length, shows changes in the condition of the fish (amount of fat stored). Deviations from the allometric curve of length and weight may indicate poor growth conditions at particular sites or in the river as a whole. Gizzard shad is the most common species at most sites. There were many YOY ( 6 to $14 \mathrm{~cm}$ ) and one year-old fish (16 to $27 \mathrm{~cm}$ ) at RM 24 and 19 (Fig. 17). Mostly larger fish (2+ years) were found at RM 38; this is a change from last year where mostly YOY and one year olds were found at this site. RM 19 had a large number of YOY gizzard shad; most of the 193 gizzard shad caught at RM 19 were YOY.

The smallmouth and striped bass were summed to show a consistent length/weight relationship at RM 38, 24, and 19 (Fig. 18). The bass appear to vary more as they get larger. This is done to the combination of the two different species. The two species are both bass; however, they are in separate families. This could be the cause of the high-end variation. The related sunfishes appear to have a looser correlation than some of the other graphs (Figure 19). This graph is a combination of the longear sunfish and bluegill. There are some YOY sunfish that do not appear to follow the growth curve too closely; they are underweight for their size. All of these fish come from RM 24 , a fast moving site. They may have a more difficult time obtaining food than YOY at other sites because they are preyed upon more heavily by larger fish in the swifter currents. The freshwater drums are found in a couple of size classes distributed in RM 24 and 19 (Fig. 20). There were no 
small $(0$ to $12 \mathrm{~cm})$ freshwater drum at RM 24 and there were only larger drum $(>20 \mathrm{~cm})$ found at $\mathrm{RM}$ 19. There were no freshwater drum found at RM 38 as there were last year. Carp at all three sites appeared to be growing equally well (Fig 21). There is a clear difference in size distribution for one year old carps and carps that are two years old or greater. The combined Catostomidae show a similar growth curve with all other fish graphed (Fig. 22). It appeared that the larger suckers were found at RM 24 and RM 19 while the smaller suckers were found mainly at RM 38.

In conclusion, pooling at RM 38 and 19 by damming or dredging, made them good nurseries for young gizzard shad and golden redhorse that contributed to their abundance. All fish species appear to be in same condition of health independent of site, based on their weight/length ratios.

Sampling Adequacy: In 1992, the total sample was subdivided into subsamples to examine variance by habitat within sites and adequacy of sampling effort to capture most of the species. In 1993 and 1994, attempts were not made to take replicates, but to maximize the habitat sample differences; hence the term subsample. At all RM locations sampled, the number of species per subsample was relatively constant (Fig. 11). The cumulative number of fish per subsample found RM 38 and RM 19 at an asymptote, but not for RM 24 (Fig. 23). RM 24 were under-sampled for number of fish; however, the fish tat were captured at this site were larger than the other sites on average.

Ordination by Detrended Correspondeace Analysis (DECORANA OR DCA): DCA is a multivariate, eigenvector matrix manipulative technique to evaluate the differences in standard deviation units between communities at particular sites or between species at those sites using an algorithm which reduces the data to two unrelated ordinates (ter Braak, 1986). Using only the species abundance data, the algorithm iterares to a solution that describes the differences in communities using only the species composition data The ordination for communities using species data is underlain by the ordination of the species in community-defined space. Using the DCA, the 
relative position of the species on each ordinate is proportional to the effect of each community on the ordinate. Hence two sites that are very dissimilar communities and share few species will be at extremes of the axis and will be significantly different if they are more than two standard deviation units apart on the axis. The eigenvector method allows us to partition the variance to determine what proportion of the separation of communities or species is explained by species or communities, respectively.

The DCA for sites using transformed species abundances (each corrected to $100 \%$ for differences in species number) showed that the fish communities of RM 38 and RM 19 were two standard deviation units apart on the first axis which explained $32.6 \%$ of the total variance in site differences. The second axis provided little separation at all among fish communities at the three sites (Fig. 24). The four subsamples were tightly clustered on the first axis at all sites compared to the variation between river mile sites.

The DCA for species by site showed associations of species responsible for separating the sites so cleanly. Similar to 1993 , the community at RM 38 above the Hamilton dams was characteristic of small or mid-order rivers with spotfin shiner, northern hog sucker, bluntnose minnow, golden shiner and yellow bullhead. Some medium-large river species separated this site: shorthead redhorse, golden redhorse, highfin carpsucker and carp. RM 24 in a narrow, fast moving section of river was dominated by Ictalurids (channel and flathead catfish), Catostomids (two buffaloes, two redhorses, and four suckers), the drum and the striped bass. Finally RM 19, pooled by gravel mining and below the CG\&E pipeline crossing, was dominated by large river fish some of that might have come from the Ohio River (sauger, gizzard shad, river carpsucker, crappie, and bluegill). Interestingly, the distribution of fish species on the first ordinate was very similar between years 1993 and 1994 . Despite the prolonged drought of 1994, the base flow was not much different between the two years 
and the factors underlying the fish distribution appeared to be similar. In 1994 compared to 1993 , the physical/chemical and biological attributes of the sites were more important to fish composition than were the microhabitats sampled in the four 10 minute subsamples.

\section{CONCLUSIONS}

The fishery of the Great Miami River has been relatively stable over the last eleven years, 1984-1994. Over the eleven years of sampling, forty-nine species have been recorded. During the 1994 survey, twenty-seven species were captured (Table 3 and Appendix A) compared with twentysix in 1993 . This year, a greater number of fish was caught, 853, compared with last year's capture of 224. The possible severe degradation of the fish community below the Fernald site, apparent in 1992, was no longer present in 1993 and 1994. RM 24 had the highest number of species caught per site this year with 20 species (Table 5), which is also the greatest number of species caught per site for any of the years surveyed.

RM 38 is protected from the upstream migration of fish by the two dams at Hamilton. In 1991, RM 38 had many redhorse and northern hogsuckers, typical for mid-sized streams prior to cultural development. However, in 1992, RM 38 was dominated by warm water species from ponded habitats, sunfish, bass, and white suckers. It appears that this year RM 38 has returned to a site dominated by river species. River species, probably breeding in isolation, were common: golden redhorse, smallmouth bass, golden shiner, and channel catfish. Low water flow this year disallowed fish navigation upriver past the dams.

RM 19 and 24 are influenced by the backwater species, which migrate up from the damregulated Ohio River. Fish from RM 38 could have originated from upstream of Hamilton or migrated up river during a previous year or during the spring high flow conditions prior to the low flow conditions. However, there are several distinct lines of evidence that suggest these dams 
prevent the summer interchange of individuals that live in the down-river reaches of the Great Miami River with those living above Hamilton.

The diversity and evenness of the sites are highly influenced by the numbers of gizzard shad and freshwater drum. RM 24 had the highest diversity, but was still dominated by freshwater drum and gizzard shad populations. RM 19 could be considered a nursery for gizzard shad since greater than $50 \%$ of the fish caught at RM 19 were YOY gizzard shad (Table 3). Sixteen additional species were found at this site; many of which are big river species such as: stripped bass, sauger, freshwater drum, carp, and large gizzard shad. Other fish species appear to be in the same condition of health, independent from site, as seen in the length/weight plots (Figs. 17 through 22).

From circumstantial evidence the fish community at RM 38 has been isolated from migration during the summer of 1993 . RM 24 and 19 can be influenced by effluents from the city of Hamilton and migration from the Ohio. River. Only one fish out of 853 collected and examined showed any sign of differential pollution stress among the three sites causing ulcers, skin fungi, and/or growth anomalies. In this regard, there are no discernible significant effects of the Fernald site on the population, size, numbers, condition, or species richness of the fish communities in the Great Miami River in 1994.

One point that was very evident in the report is the importance of multiple subsamples. The DCA showed that subsamples clustered tightly for all RM sites with no overlap on axis one at all. Subsamples were larger in 1994 and sufficiem to represent the fish community based on the criteria of reaching a species number asymptote (Fig 23)

Fish communities are good indices of water quality and habitat quality. In the absence of pollutant stressors, fish species utilize river sections by their unique habitat requirements. In 1994, habitat differences appeared to be connected with fish community structure by site, similar to the 
conclusion reached in 1993. In 1992, the survey appeared to show that fish were separated by an upstream source of nutrient enrichment. This enrichment set up a gradient of decreasing water quality and fish community species richness down river. This condition was not repeated in the late summer of 1993 or 1994 despite the low water flow. The 1994 survey tended to have more fish collected and a larger average size. 


\section{REFERENCES}

Beckett, D.C. 1977. Compositional Variation and Ordination of Macroinvertebrates in a Multistressed River System. Masters of Science Thesis. 76 p.

Beckett, D.C. 1978. Ordination of Macroinvertebrate Communities in a Multi-stressed River System. p. 748-770. In J.H. Thorp and J.W Gibbons (eds.) Energy and Environmental Stress in Aquatic Systems. CONF-771144 NTIS. Springvalley, VA.

Boschung Jr., H. T., J. D. Williams, D. W. Gotshall, D. K. Caldwell, and M. C. Caldwell. 1983. The Audubon Society Field Guise to North American Fishes, Whales and Dolphins. Alfred A. Knopf, Inc., New York. 848p.

Clay, W.M. 1975. The fishes of Kentucky. Kentucky Dept. of Fish \& Wildlife Resources, Frankfort, Ky. p 416.

Gammon, J.R. 1973. The effect of thermal inputs on the populations of fish and macroinvertebrates in the Wabash River. Purdue Univer. Water Research Center Tech. Rept. no. 86.

Gammon, J.R. 1976a. The fish population of the middle $340 \mathrm{~km}$ of the Wabash River. Purdue Univer. Water Research Center Tech. Rept. No. 32.

Gammon, J.R. 1976b. The fish populations of the middle $340 \mathrm{~km}$ of the Wabash River. Purdue Univer. Water Resources Res. Cen. Tech. Rep. 86. 73p.

Gammon, J.R., M.D. Johnson, C.E. Mays, D.A. Schiappa, W.L. Fisher and B. L. Pearman. 1983. Effects of Agriculture on Stream Fauna in Central Indiana. USEPA. EPA-600/S3-83-020. $5 \mathrm{p}$.

Karr, J.R. 1981. Assessment of biotic integrity using fish communities. Fisheries 6(6): 21-27.

Karr, J. D., K. D. Fausch, P. 1. Angermier, P. R. Yant, and I. J. Schlosser. 1986. Assessing Biological Integrity in Running Waters: A Method and its Rationale. IIl. Nat. Hist. Surv. Spec. Publ. S. $28 \mathrm{p}$.

Krebs, C.J. 1989. Ecological Methods. Harper and Row, N.Y.654p.

Krumholz, L.A. 1981. Observations in changes in the fish population of the Ohio River from Rafinesque to 1980. Trans. Ky. Acad. Sci. 41: 1-15.

Miller, M. C., G. Gibeau, M. Kelly, J. Schneider, and T. Linnabary. 1987. Fish of the Great Miami River 10 September 1987. Draft Report, Westinghouse Materials Company of Ohio, Cincinnati, OH. p. 39.

Moller, B.J. 1986. Corlisol Levels in Carp (Cyprimus carpio) from the Great Miami River as an Indicator of Environmentally Induced Stress. Masters of Science Thesis, $84 \mathrm{p}$.

OEPA. 1988. Biological Criteria for the Protection of Aquatic Life: Vol. II: Users Manual for Biological Field Assessment of Ohio Surface Waters. Div. of Water Quality Planning and Assessment. OEPA. 124p.

OEPA. 1990. Compendium of Biological Results from Ohio Rivers, Streams and Lakes: 1989 Edition. Division of Water Quality Planning \& Assessment, OEPA. 132p.

Ohio River Valey Water Sanitation Commission. 1962. Aquatic Life Resources of the Ohio River. ORSANCO, Cincinnati, OH. 218p.

ORSANCO. 1980. Assessment of Water Quality Conditions, Ohio River Mainstem 1978-1979. Ohio River Sanitation Commission, Cincinnati.

Page, Lawrence M. and Bur, Brooks M. 1991. A Field Guide to Freshwater Fishes. Peterson Field Guides, Houghton Mifflin Co., Boston. 432p.

Pearson, W.D. and L.A. Krumholz. 1984. Distribution and status of Ohio River fishes. ORNL 
/SUB/79-7831/1. Oak Ridge Nat. Lab., Oak Ridge, TN. 401p.

Pearson, W.D. and B.J. Pearson. 1989. Fishes of the Ohio River. Ohio J. Sci. 89: 181-187.

Pflieger, W.L. 1975. The fishes of Missouri. Missouri Dept. of Conservation. 342p.

Rankin, E.T., C.O. Yoder, \& D. Mishne. 1990. Ohio Water Resource Inventory-Executive Summary \& Vol. 1. OEPA. Columbus. 136p.

Smith, P.W. 1979. The fishes of Illinois. U. of Illinois Press, Urbana.Ill. 413p.

Ter Braak, C.J.F. 1986. Canonical correspondence analysis: a new eigenvector technique for multivartiate direct gradient analysis. Ecology 67: 1167-1179.

Trautman, M. B. 1981. The fishes of Ohio. Ohio State U. Press. 782p.

Vibert, R.(ed.). 1967. Fishing with electricity. F.A.O. United Nations. 276p.

Vondracek, B. and Robert LeHew. 1992. Population dynamics and ecology of Lake Erie gizzard shad. In "Ohio Cooperative Fish and Wildlife Research Unit, 1991 Annual Report", ODW, OSU, USFWS and WMI. 54p.

Wetzel, R.G. 1983. Limnology 2nd ed. Saunders, Philadelphia. 767p.

Wetzel. R. and G.E. Likens. 1991. Limnological Analyses. Second Edition. Springer-Verlag, New York 39lp.

Yoder, C.O. and J.R. Gammon. 1976. Spatial and temporal distributions and abundance of fishes in the Middle Ohio River. Rept. for Dayton Power and Light Co. 113p. 
Figure 1. Overview map of the sampling sites in the Great Miami River, 1994.

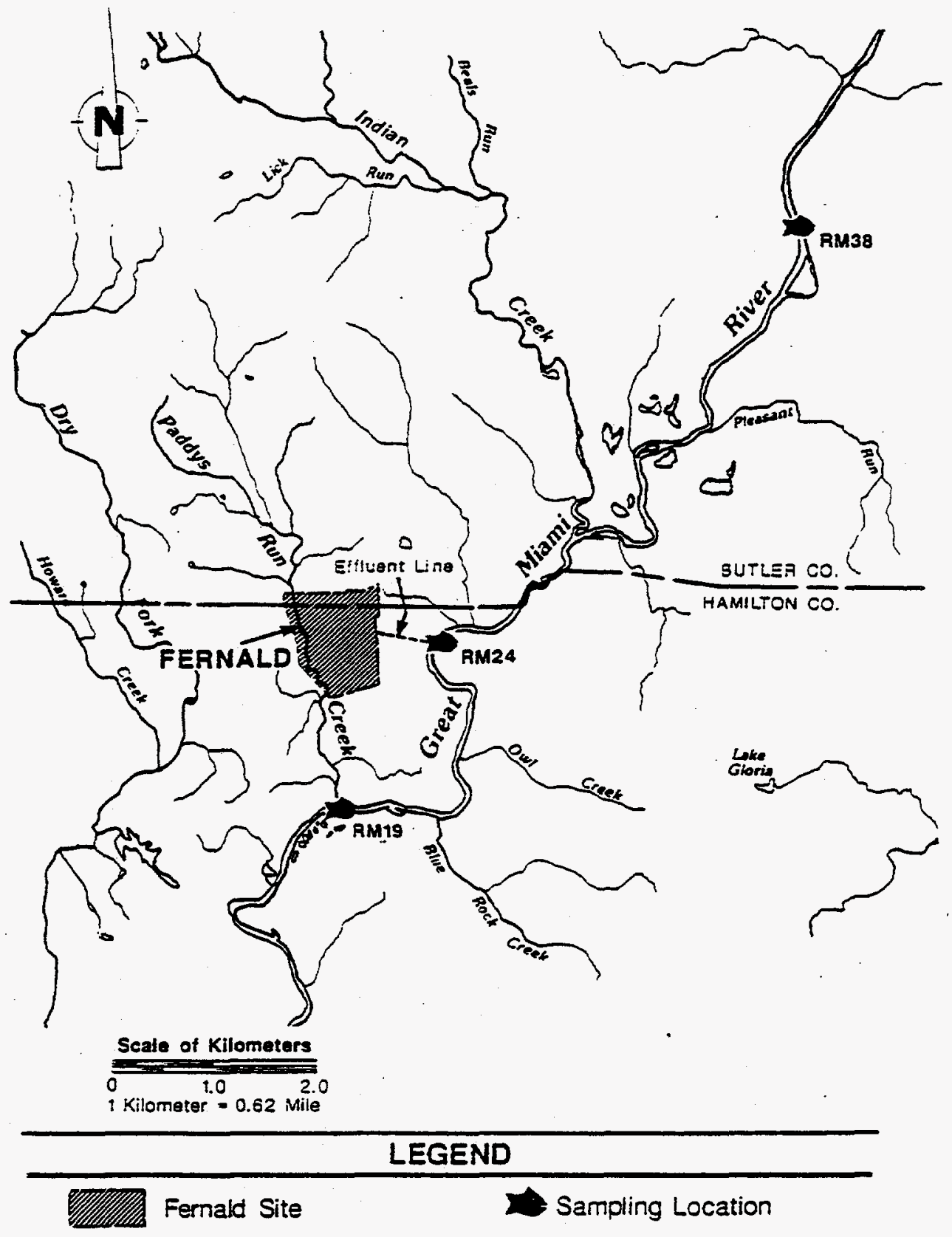


Figure 2. Map of river mile 38

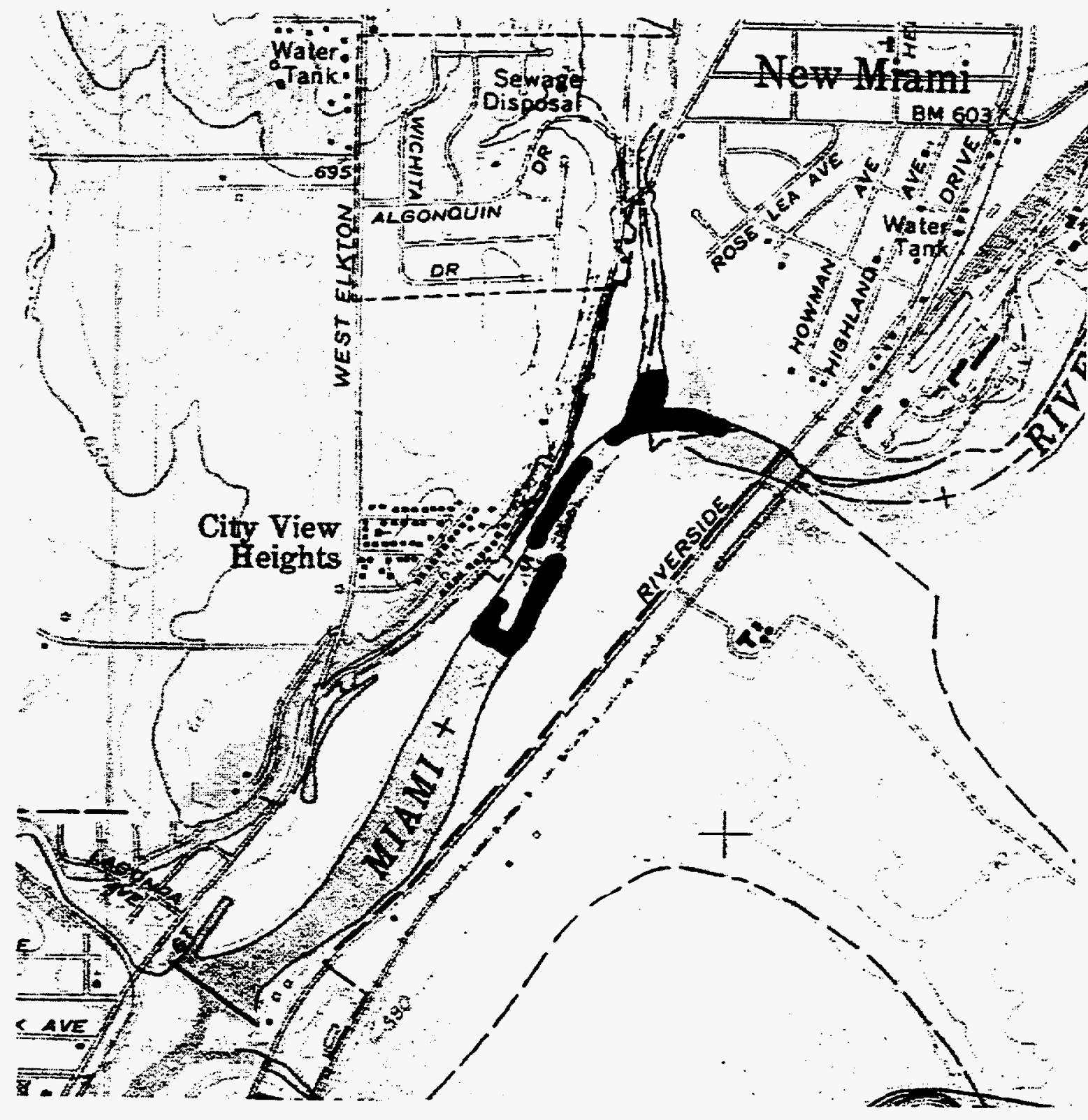


Figure 3. Map of river mile 24 .

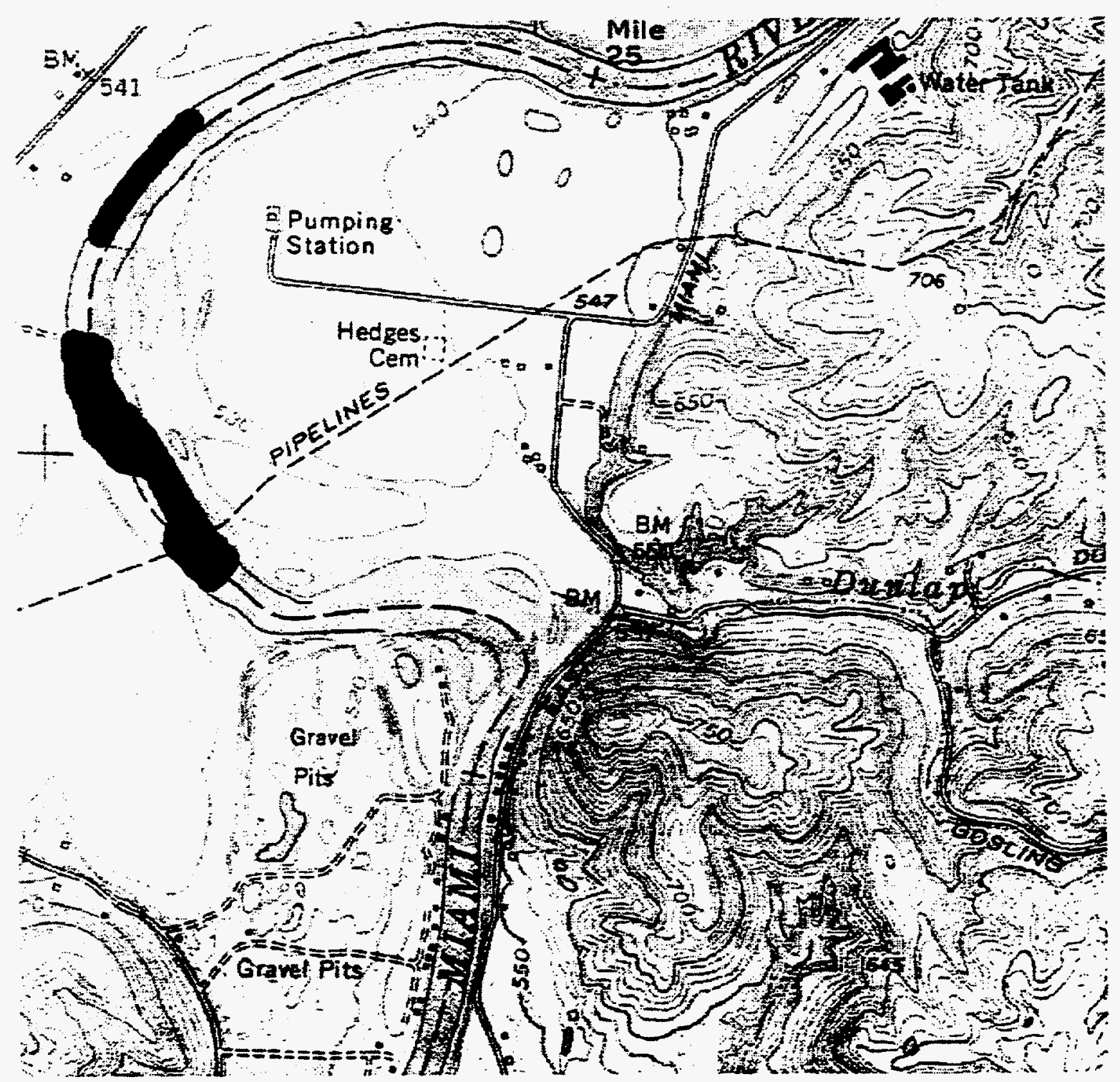


Figure 4. Map of river mile 19

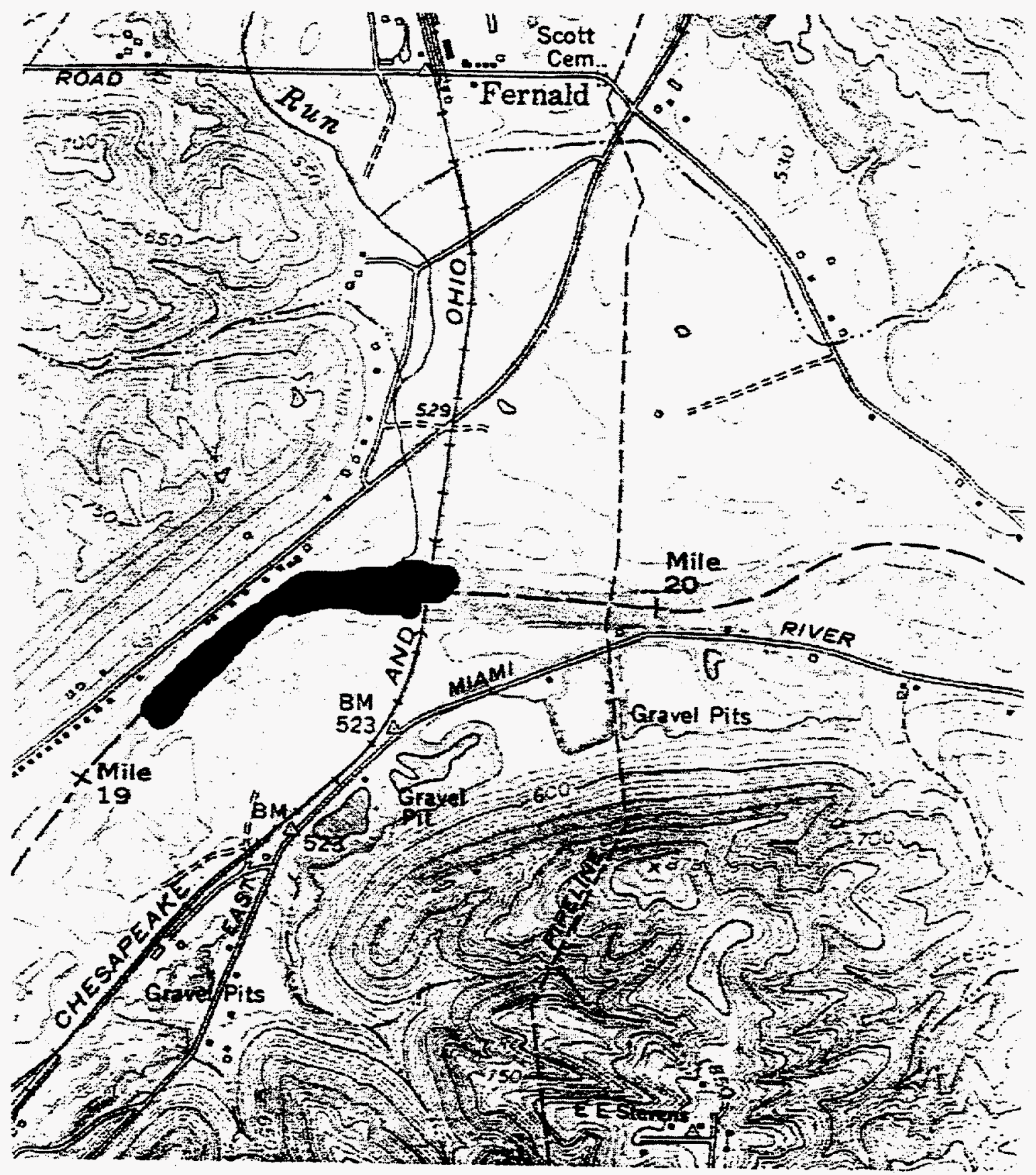


Figure 5. Index of Biotic Integrity, Index of Well Being, and Index of Habitat Quality in the Great Miami River from the Ohio River (RM 0) to Dayton (RM 50) from OEPA data, $1980,1987,1989$.

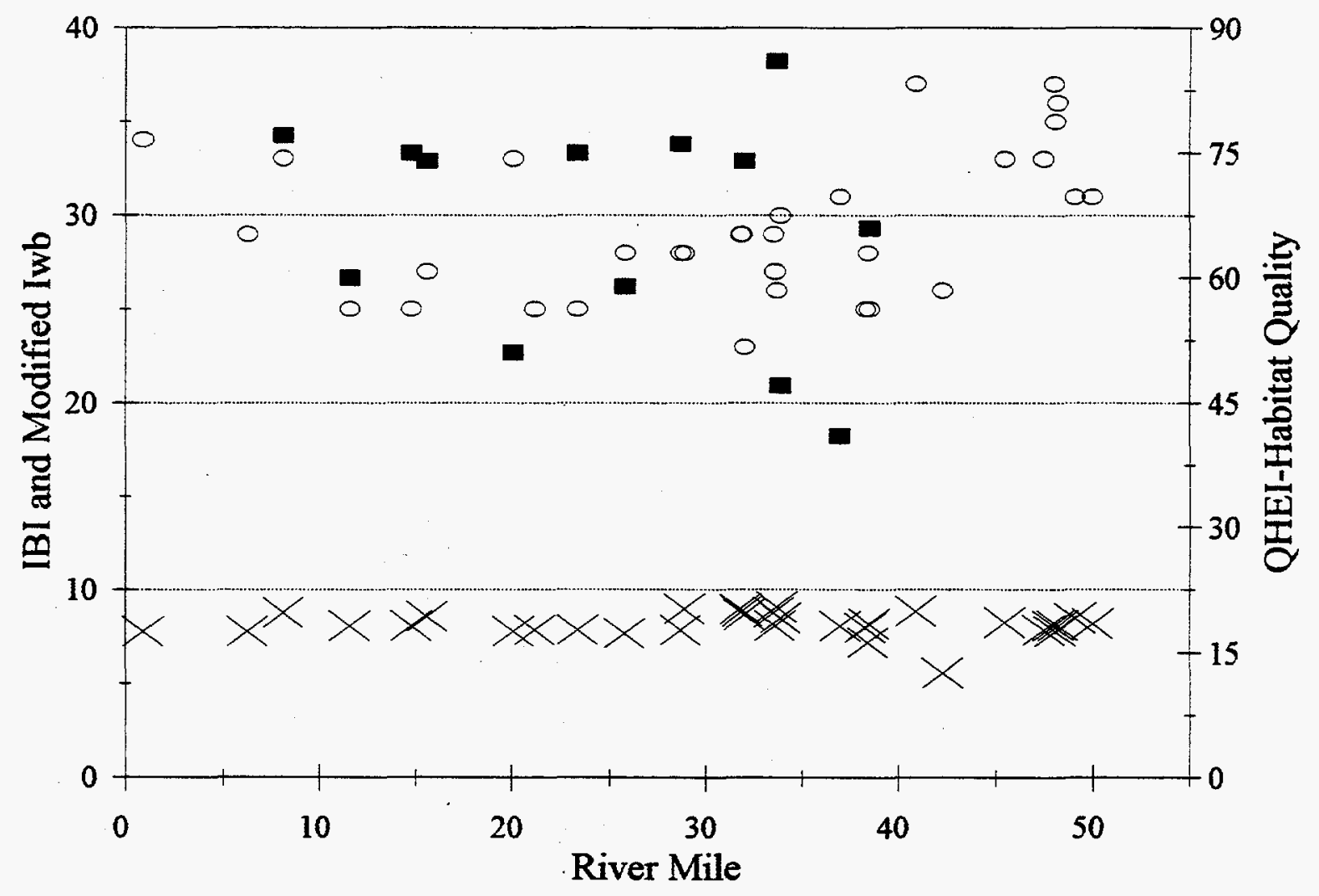

$\circ$ IBI $\quad$ QHEI $\times$ Mod Iwb


Figure 6. Phosphate, nitrate, and ammonia concentrations found at each site in the Great Miami River, 1994.

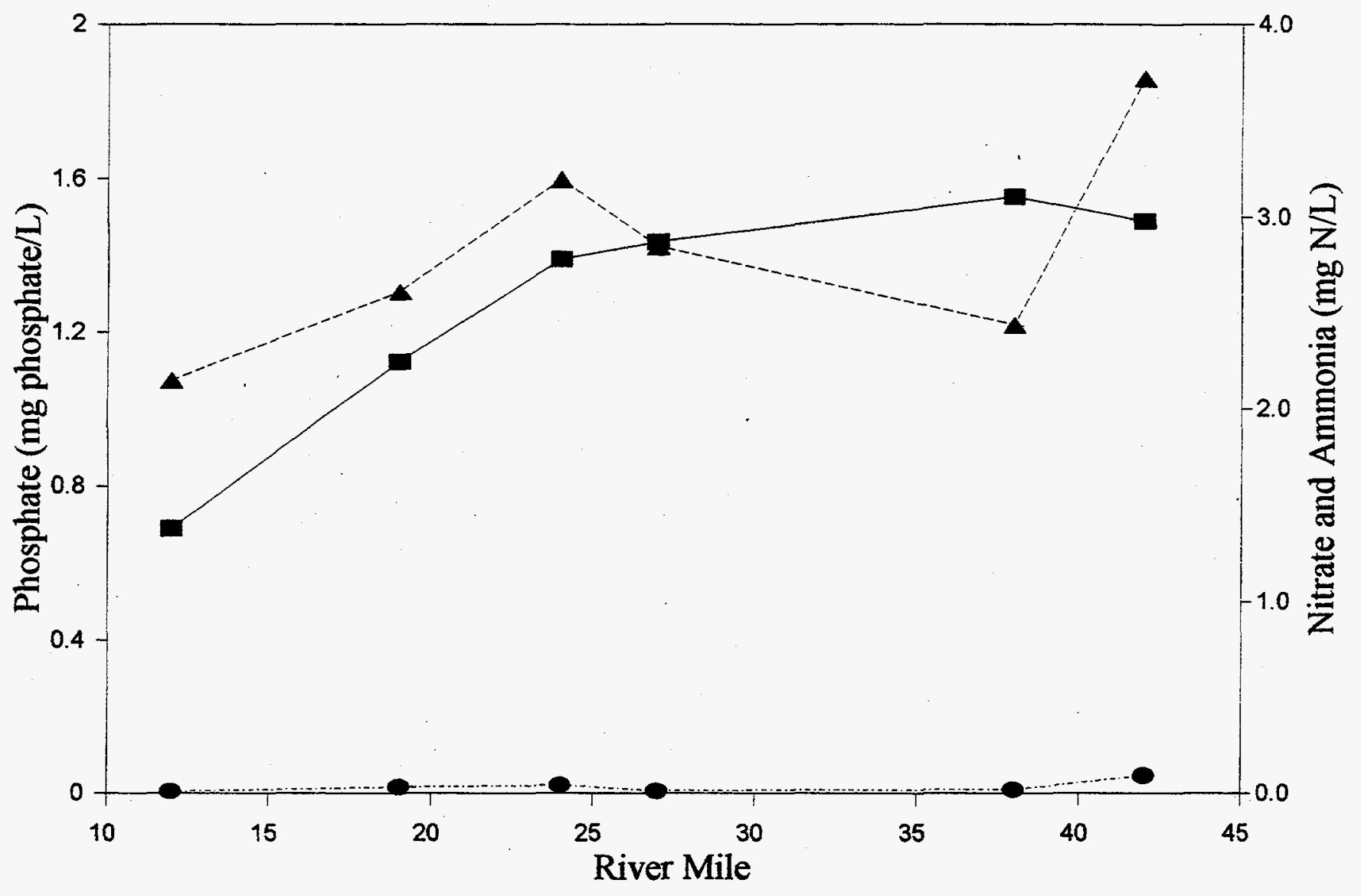

- Phosphate - Nitrate - Ammonia 
Figure 7. Sulfate concentrations and conductivity levels found at each site in the Great Miami River, 1994.

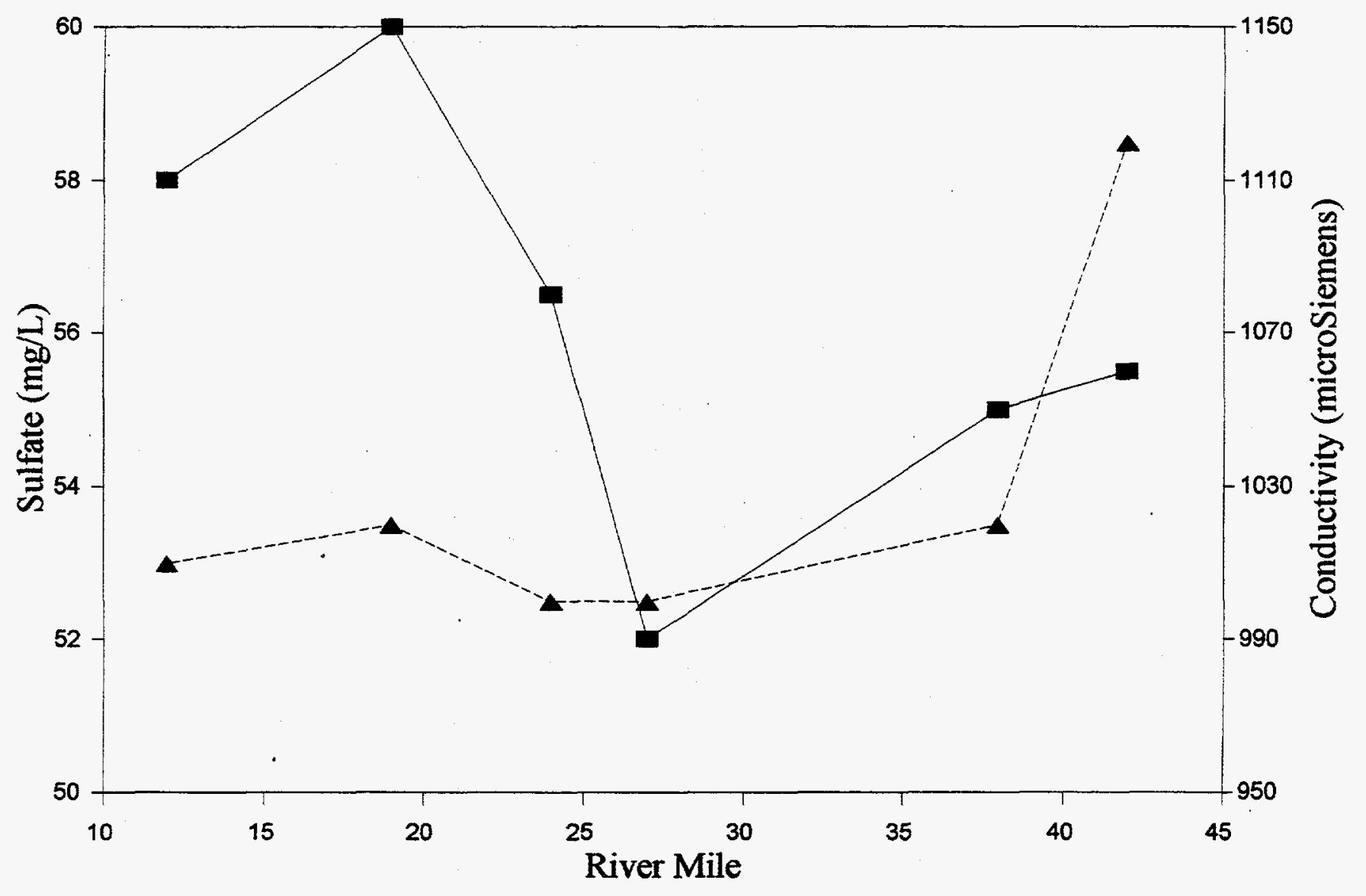

- - Sulfate $\quad-$ Conductivity 
Figure 8. Levels of $\mathrm{pH}$ and oxygen concentrations found at each site in the Great Miami River, 1994.

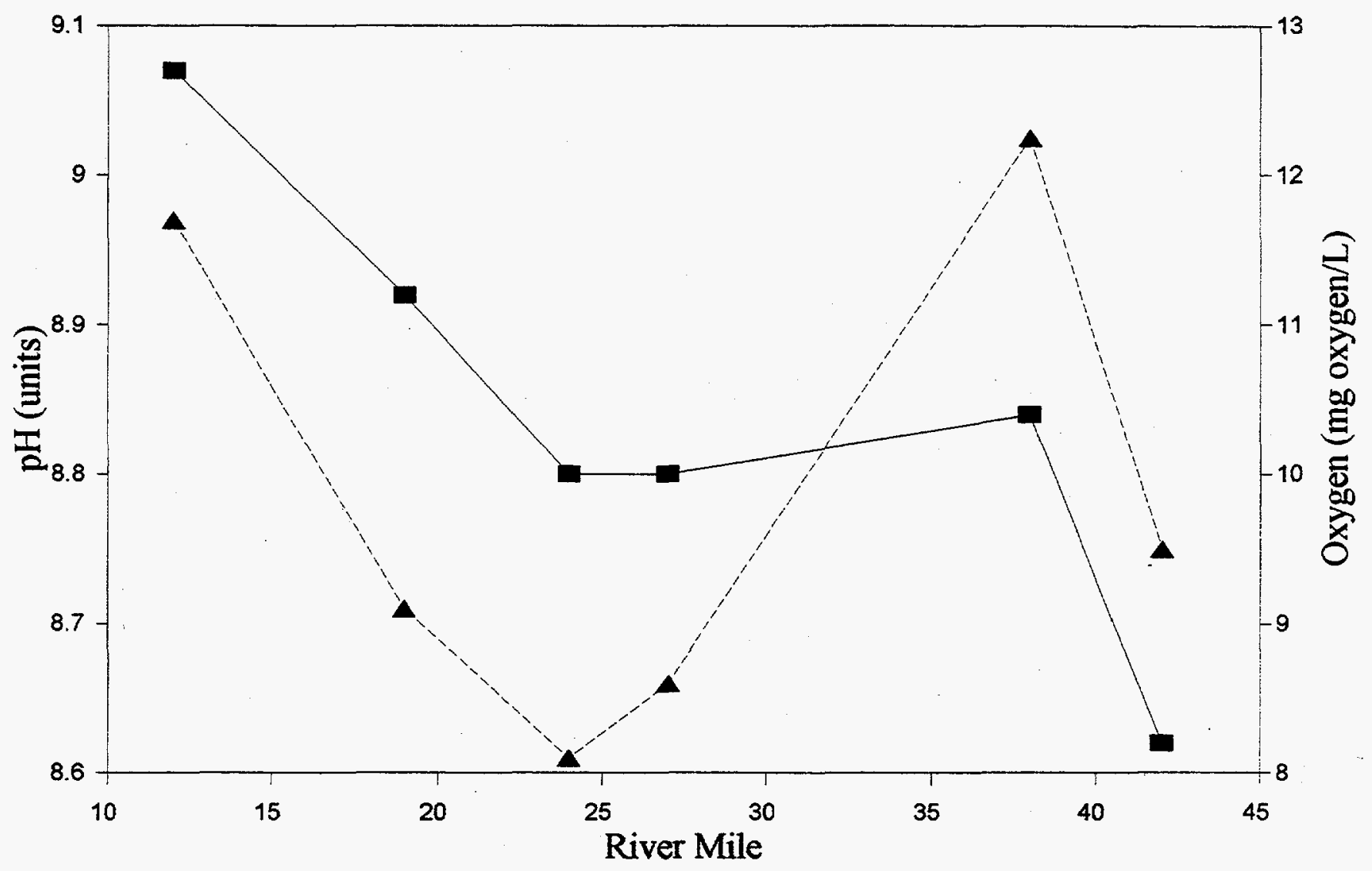

$\rightarrow-\mathrm{pH} \quad-$ - Oxygen 
Figure 9. Inorganic nitrogen to phosphorus ratio, by weight, for each site in the Great Miami River, 1994.

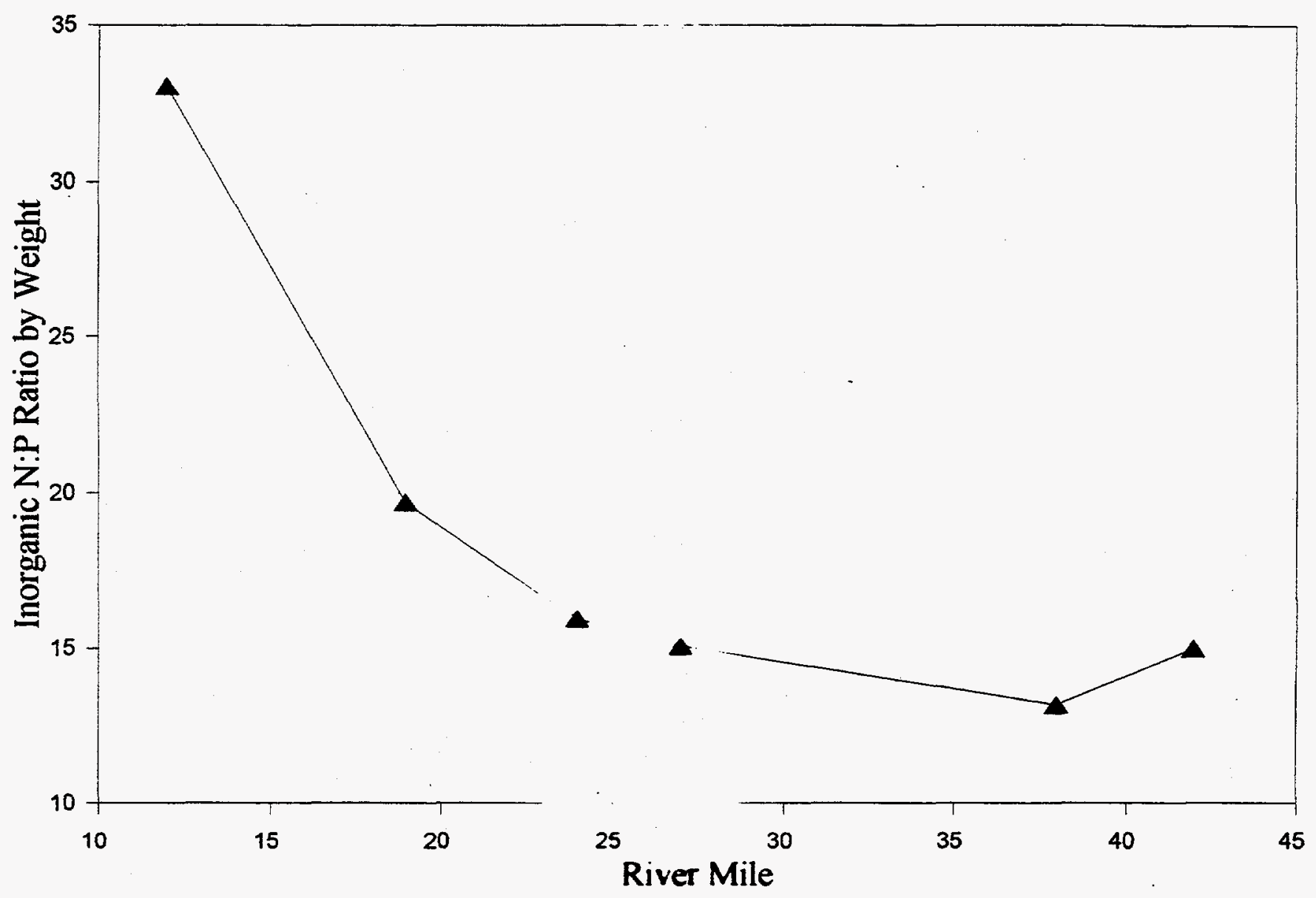


Figure 10. The number of species and the number of fish per site in the Great Miami River, 1994.

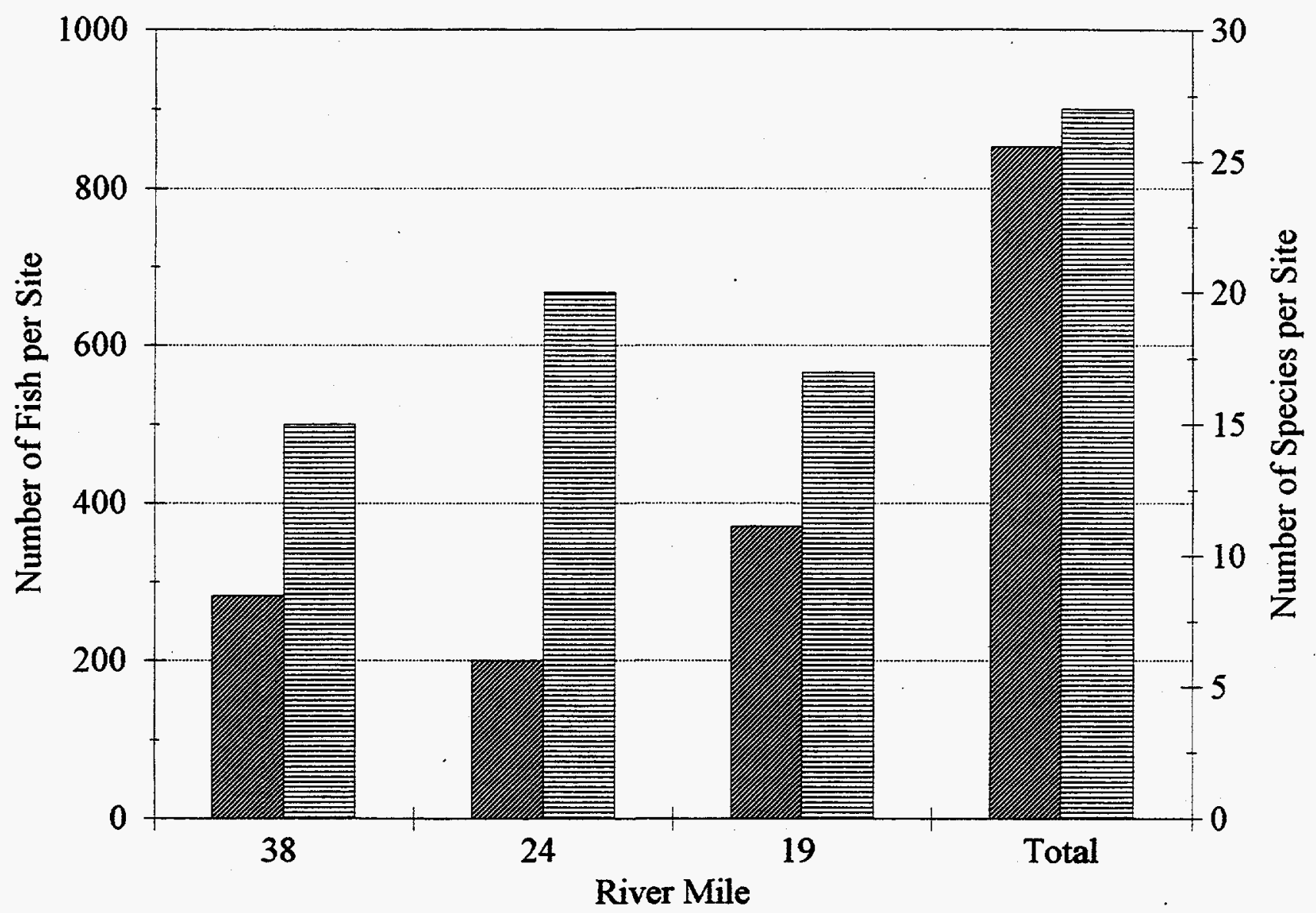

Fish per Site Species per Site 
Figure 11. The number of fish species in four subsamples at three river sites in the Great Miami River, 1994.

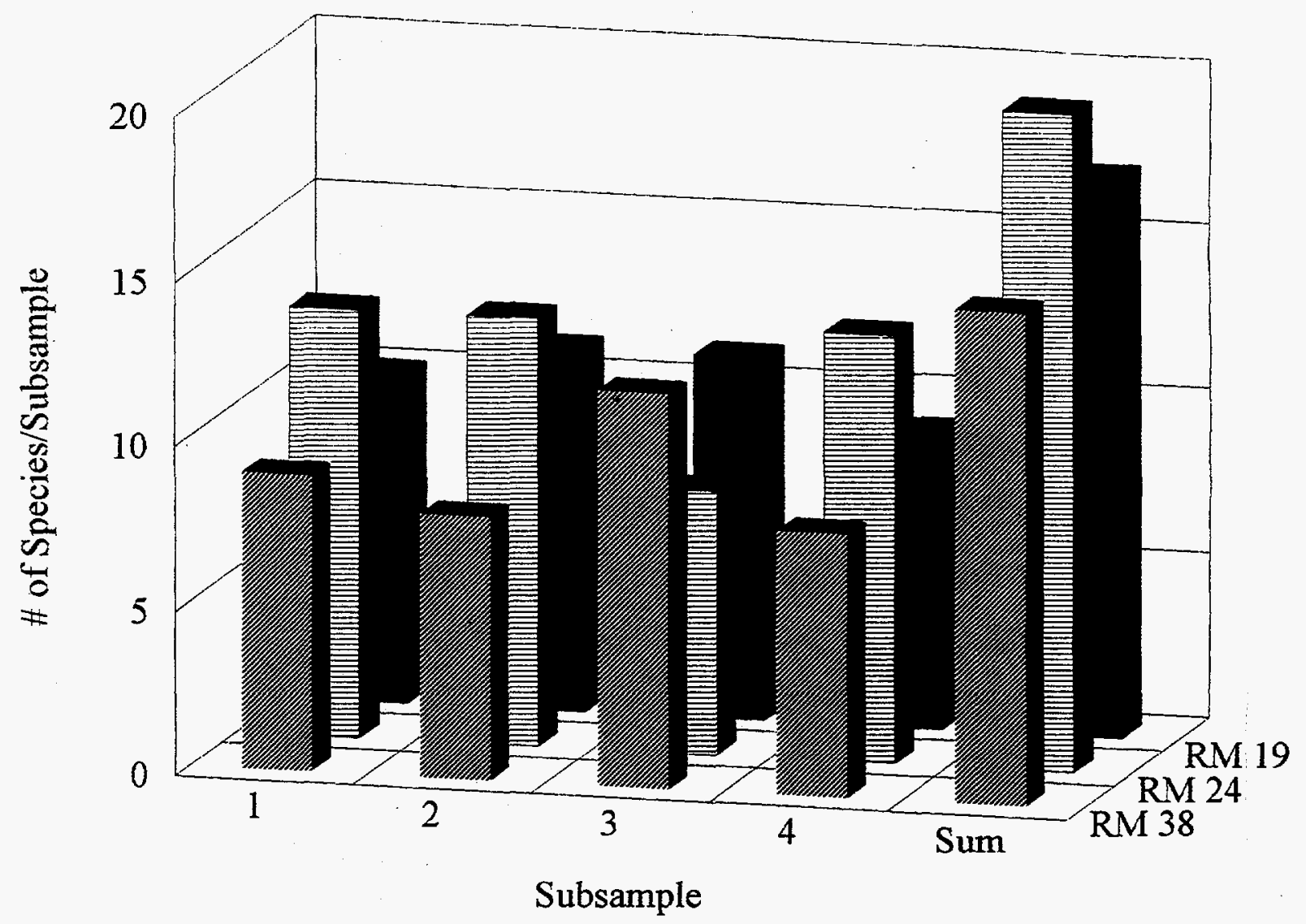

Note: The duration of each subsample was approximately 10 minutes. 
.Figure 12. The number of fish caught per hour and the number of fish caught per kilometer in the Great Miami River, 1994.

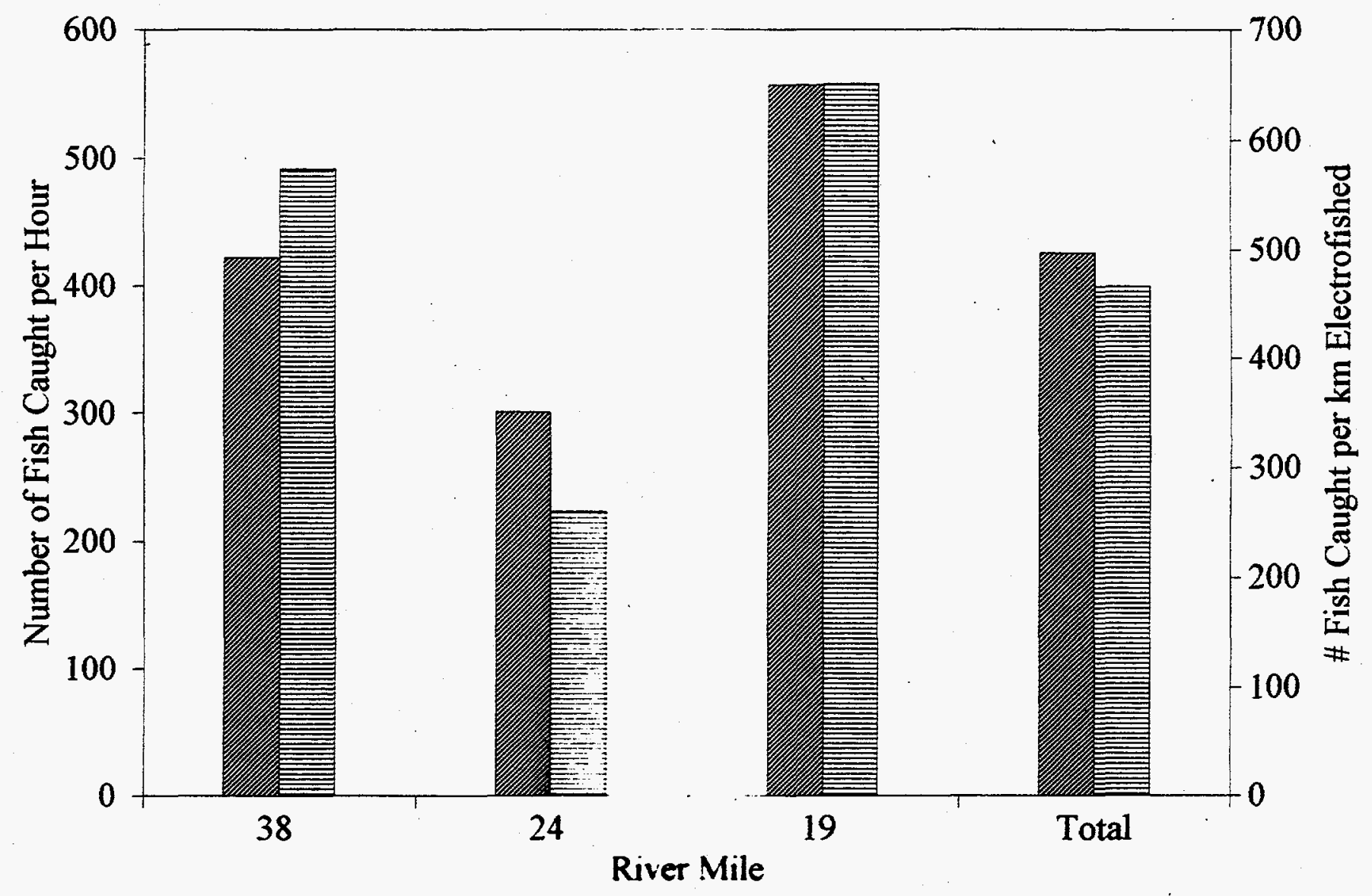

\section{Ind Fish per Hour $\cdots$ Fish per km}


Figure 13. The total weight and the biomass per hour of fish captured at each site in the Great Miami River, 1994.




Figure 14. Shannon Diversity Index of fish captured in the Great Miami River, 1994.

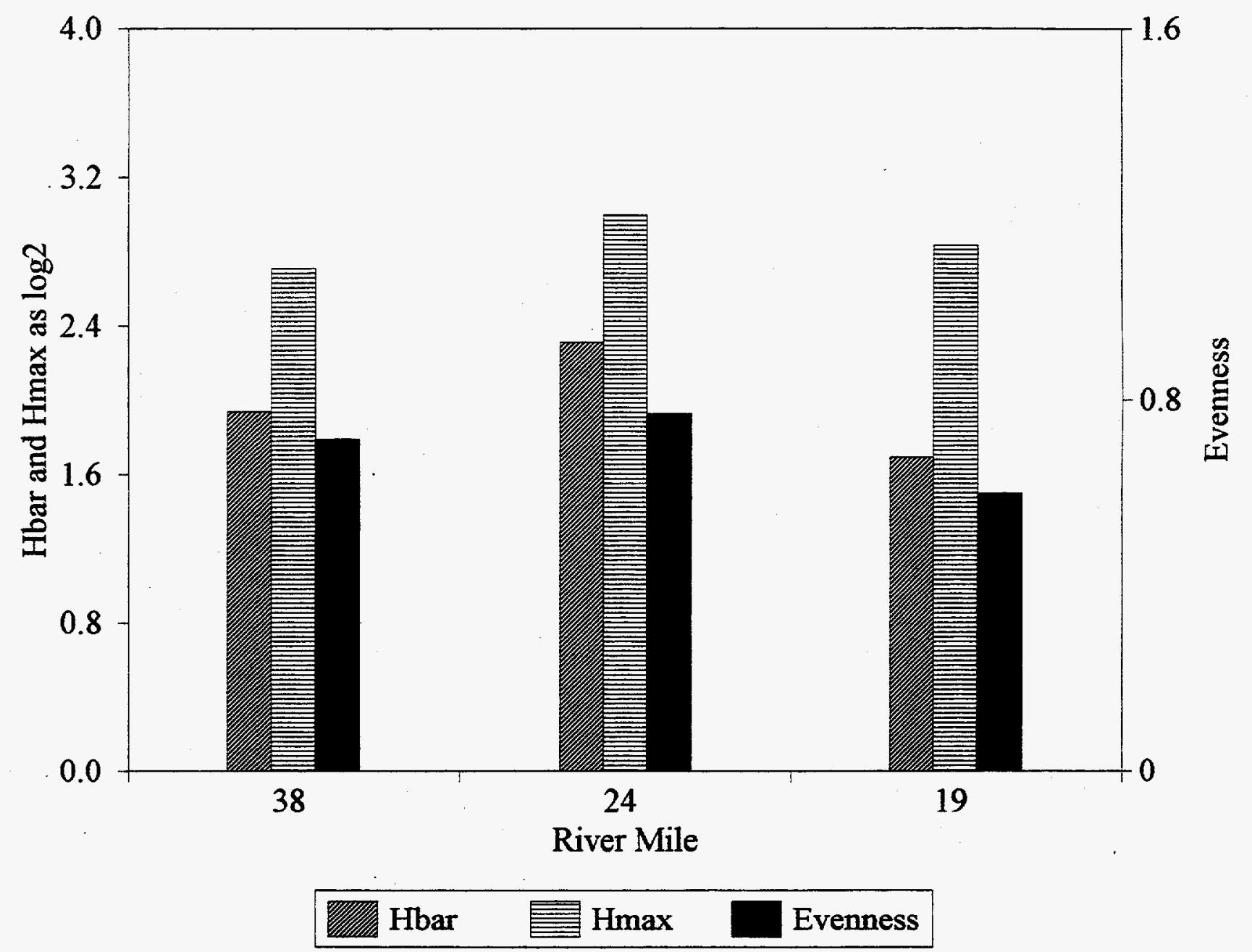


Figure 15. The cumulative proportion of fish by weight captured in the Great Miami River, 1994.



$־ \mathrm{RM} 38 \multimap \mathrm{RM} 24 \multimap \mathrm{RM} 19$ 
Figure 16. The cumulative proportion of fish by length captured in the Great Miami River, 1994.

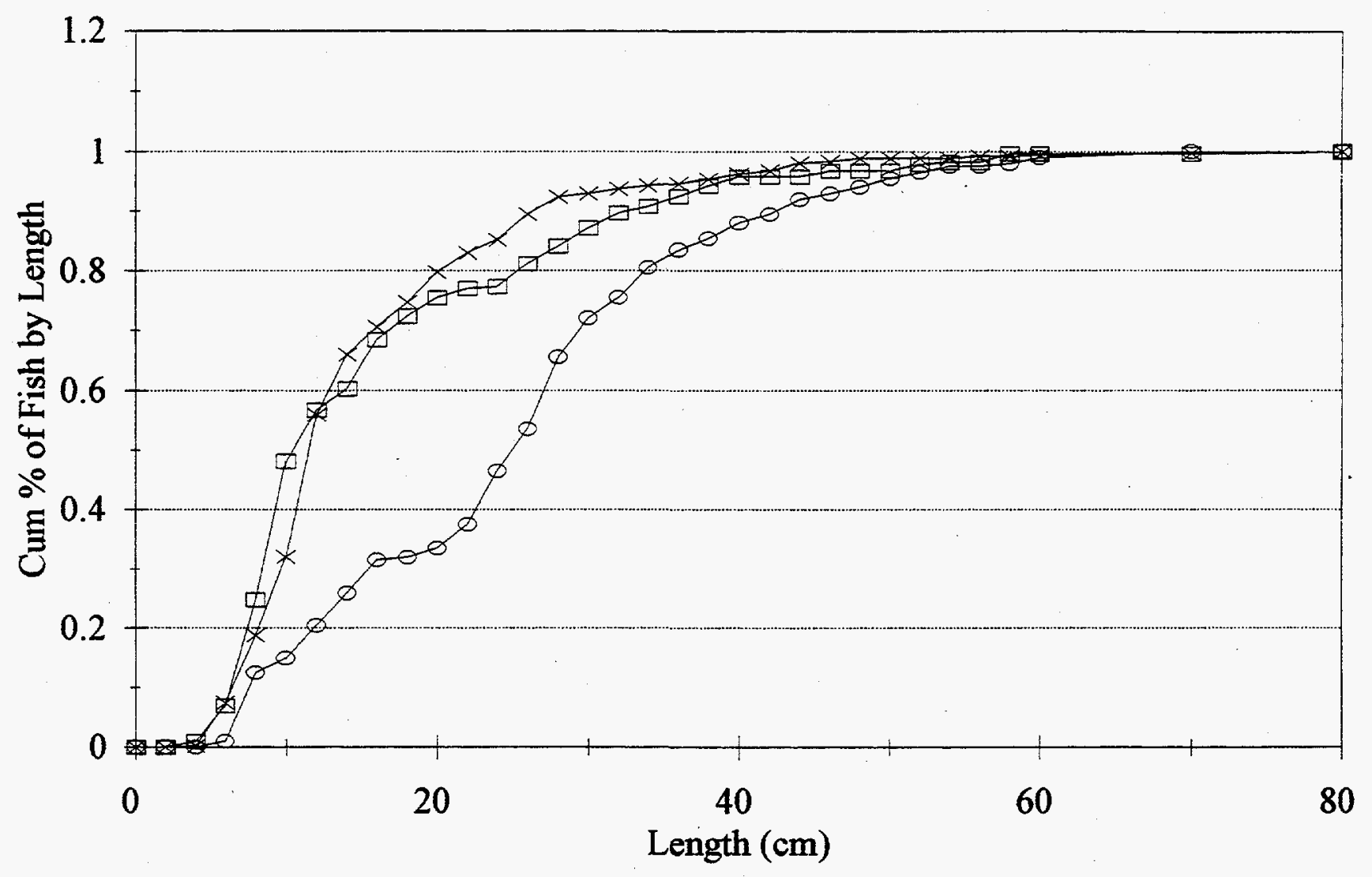

$\mp \mathrm{RM} 38 \multimap \mathrm{RM} 24 \multimap \mathrm{RM} 19$ 
Figure 17. Length/weight relationship for gizzard shad in the Great Miami River, 1994.

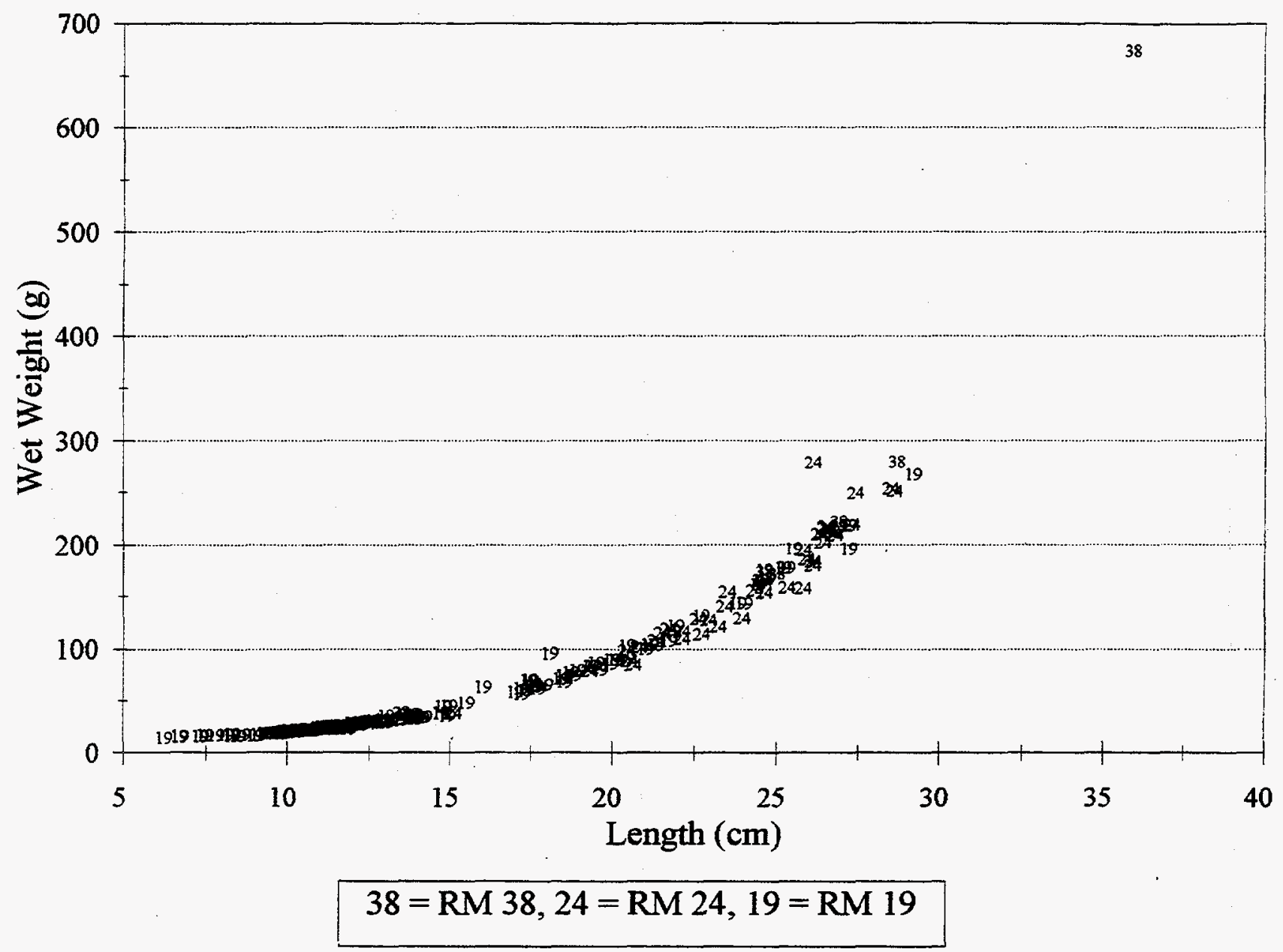


Figure 18. Length/weight relationship for striped and smallmouth bass in the Great Miami River, 1994.

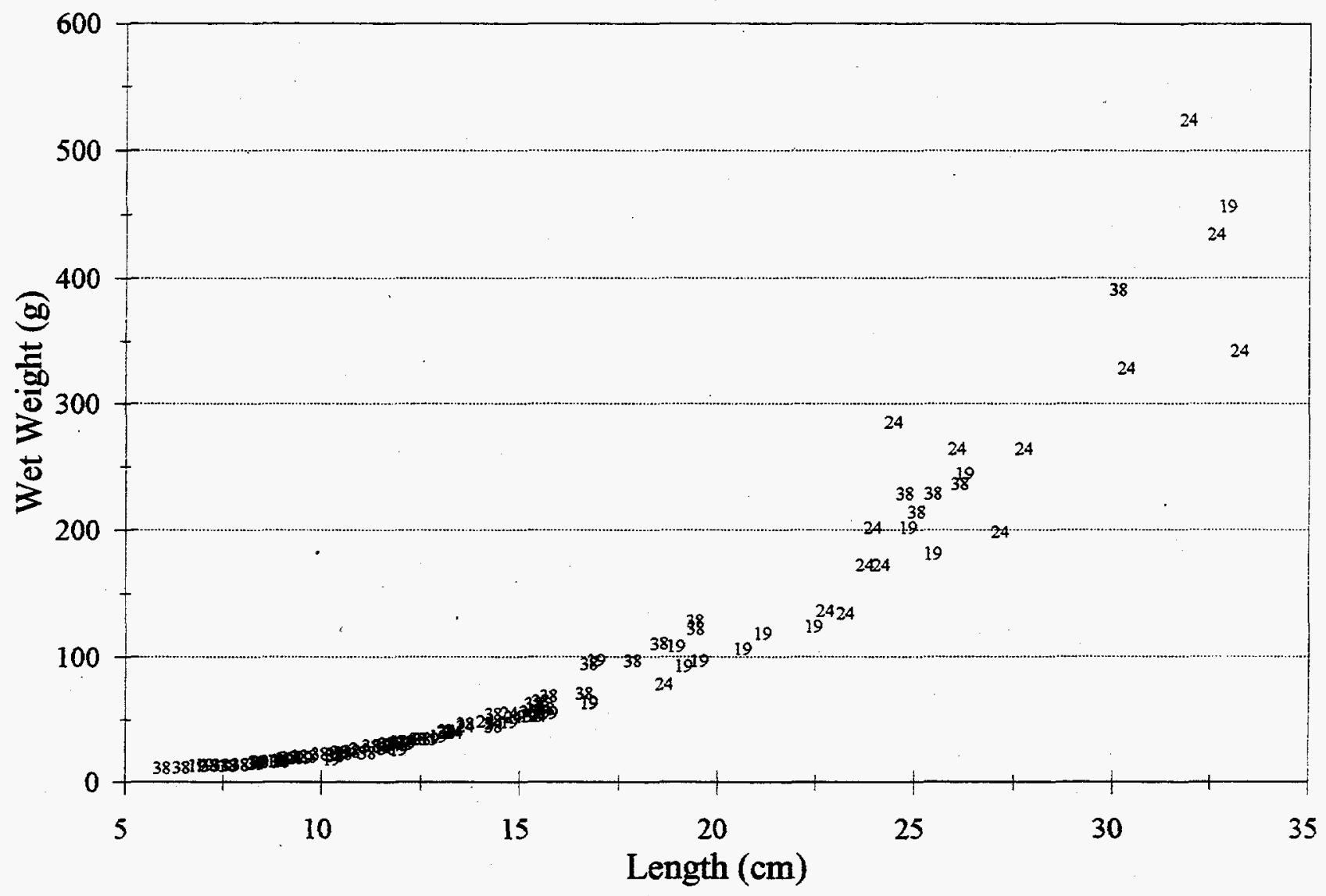

$$
38=\mathrm{RM} 38,24=\mathrm{RM} 24,19=\mathrm{RM} 19
$$


Figure 19. Length/weight relationship for sunfish in the Great Miami River, 1994.

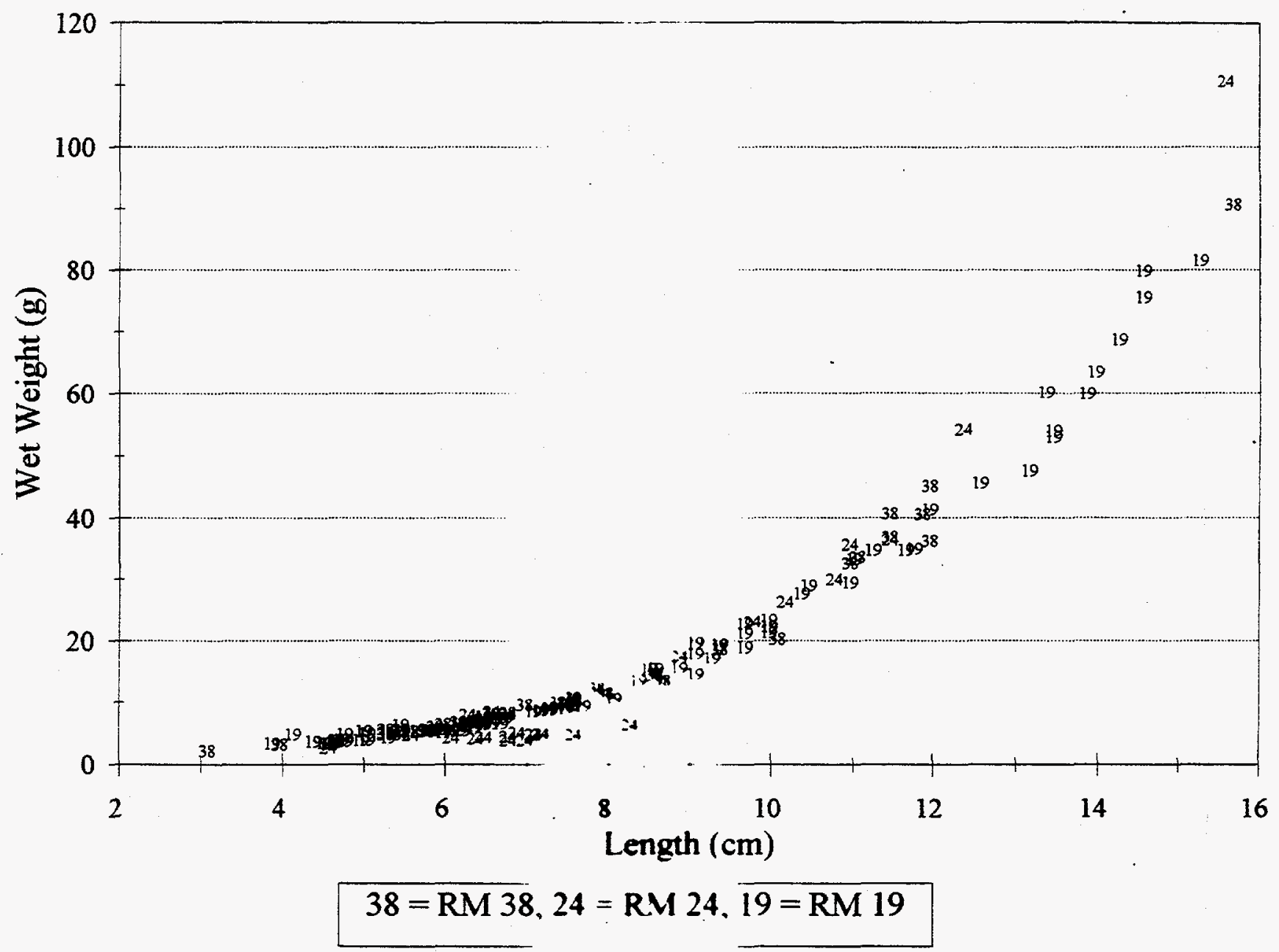


Figure 20. Length/weight relationship for freshwater drum in the Great Miami River, 1994.

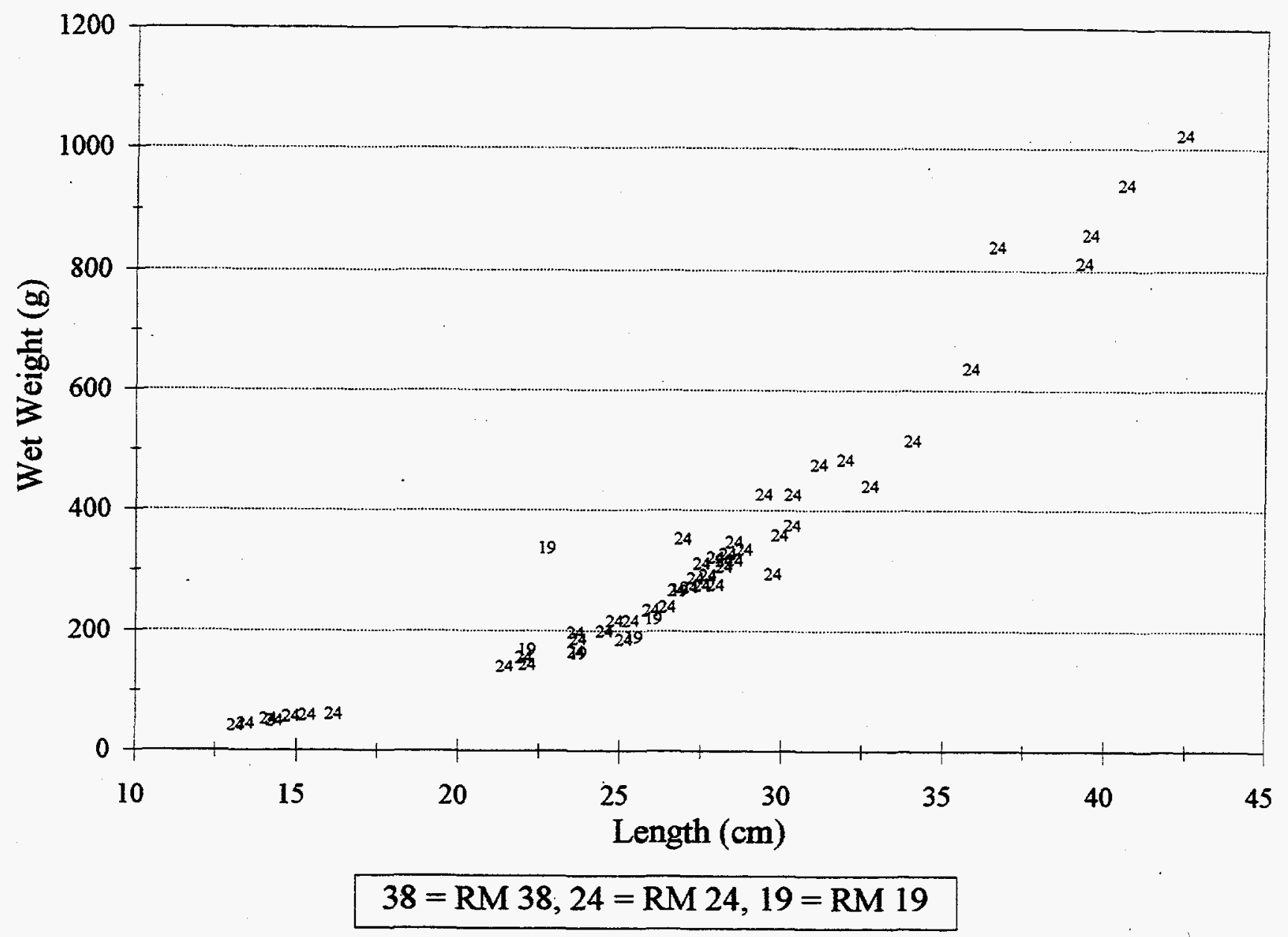


Figure 21. Length/weight relationship for carp in the Great Miami River, 1994.

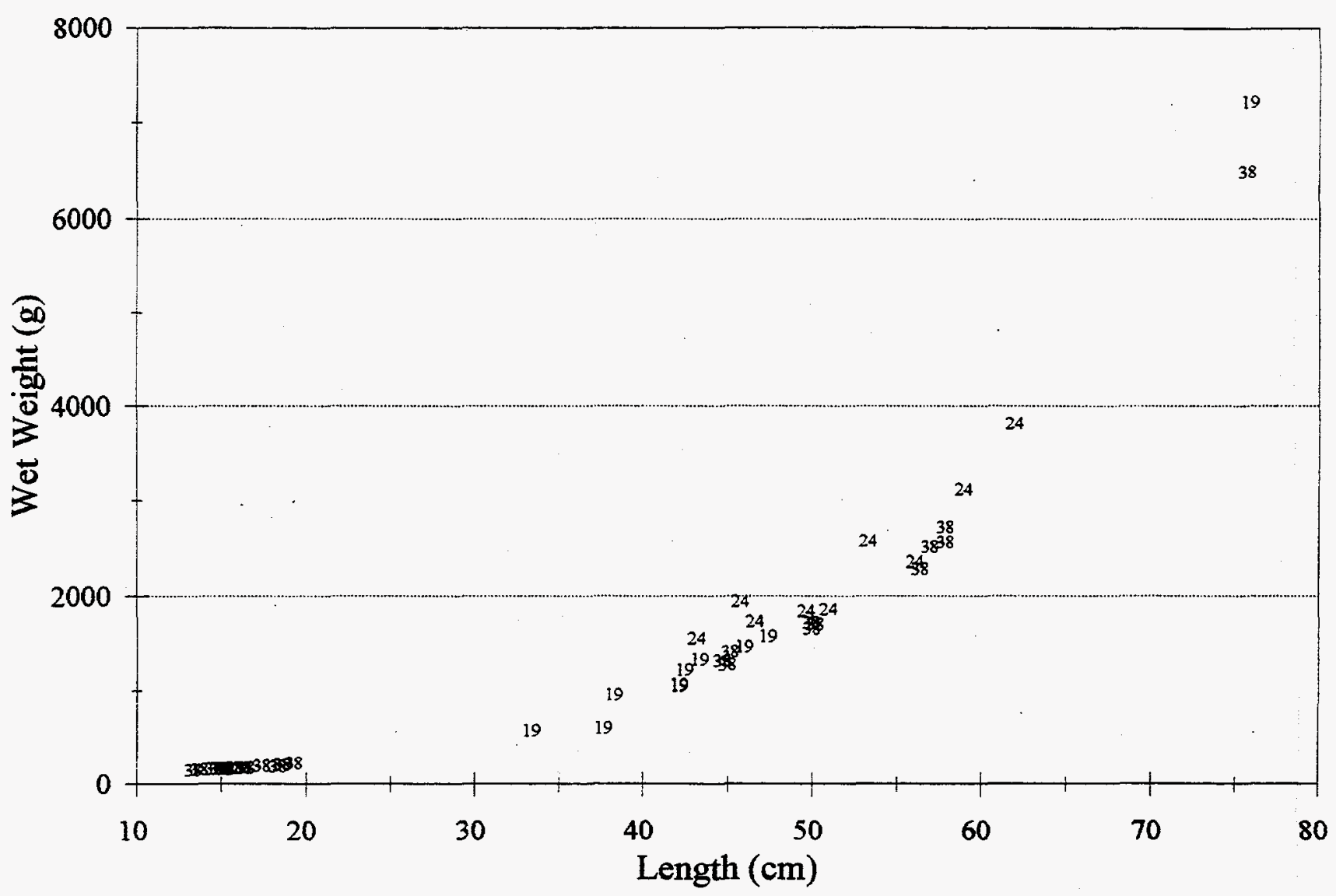

$$
38=\mathrm{RM} 38,24=\mathrm{RM} 24,19=\mathrm{RM} 19
$$


Figure 22. Length/weight relationship for Catostomidae in the Great Miami River, 1994.

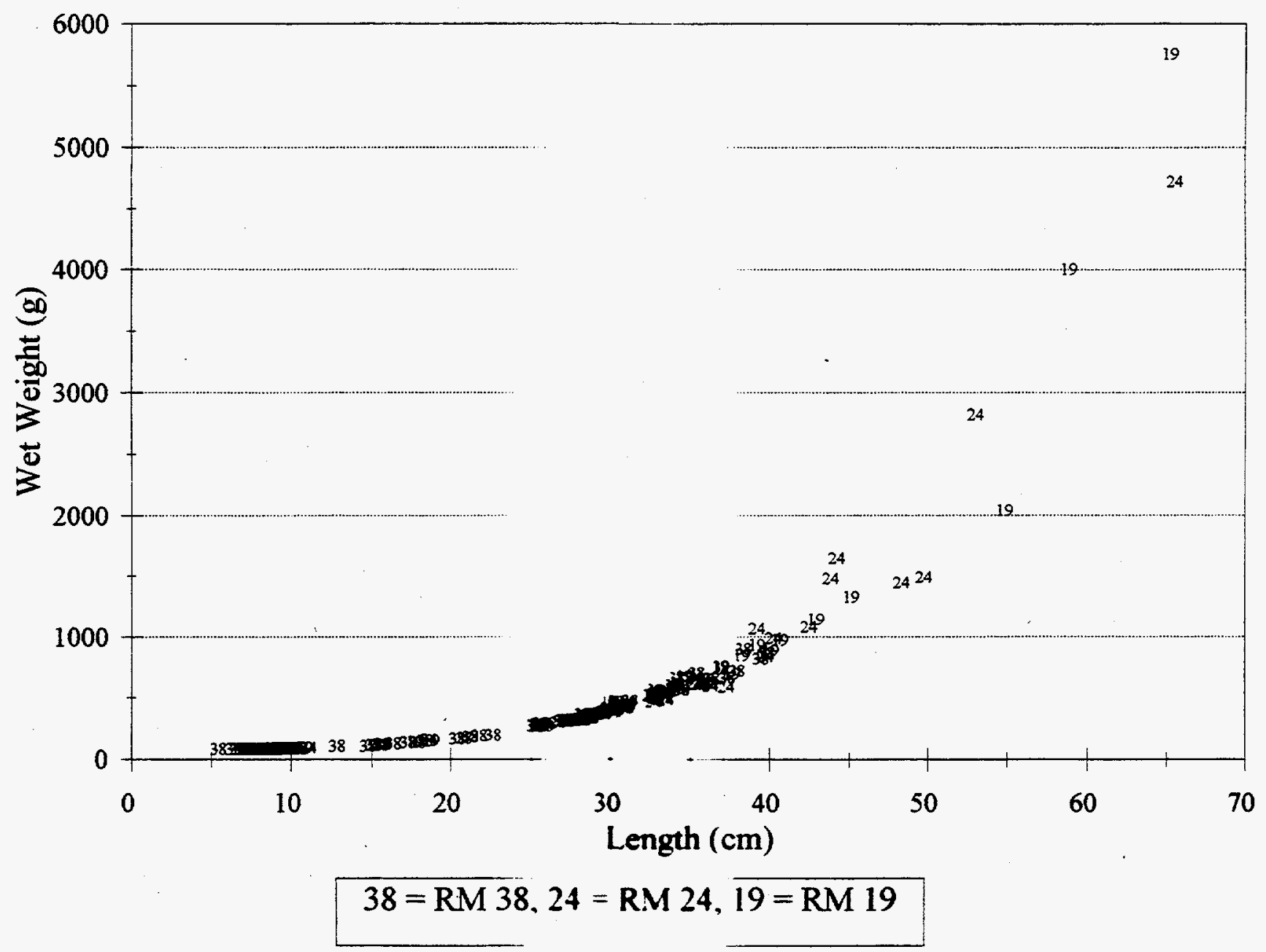




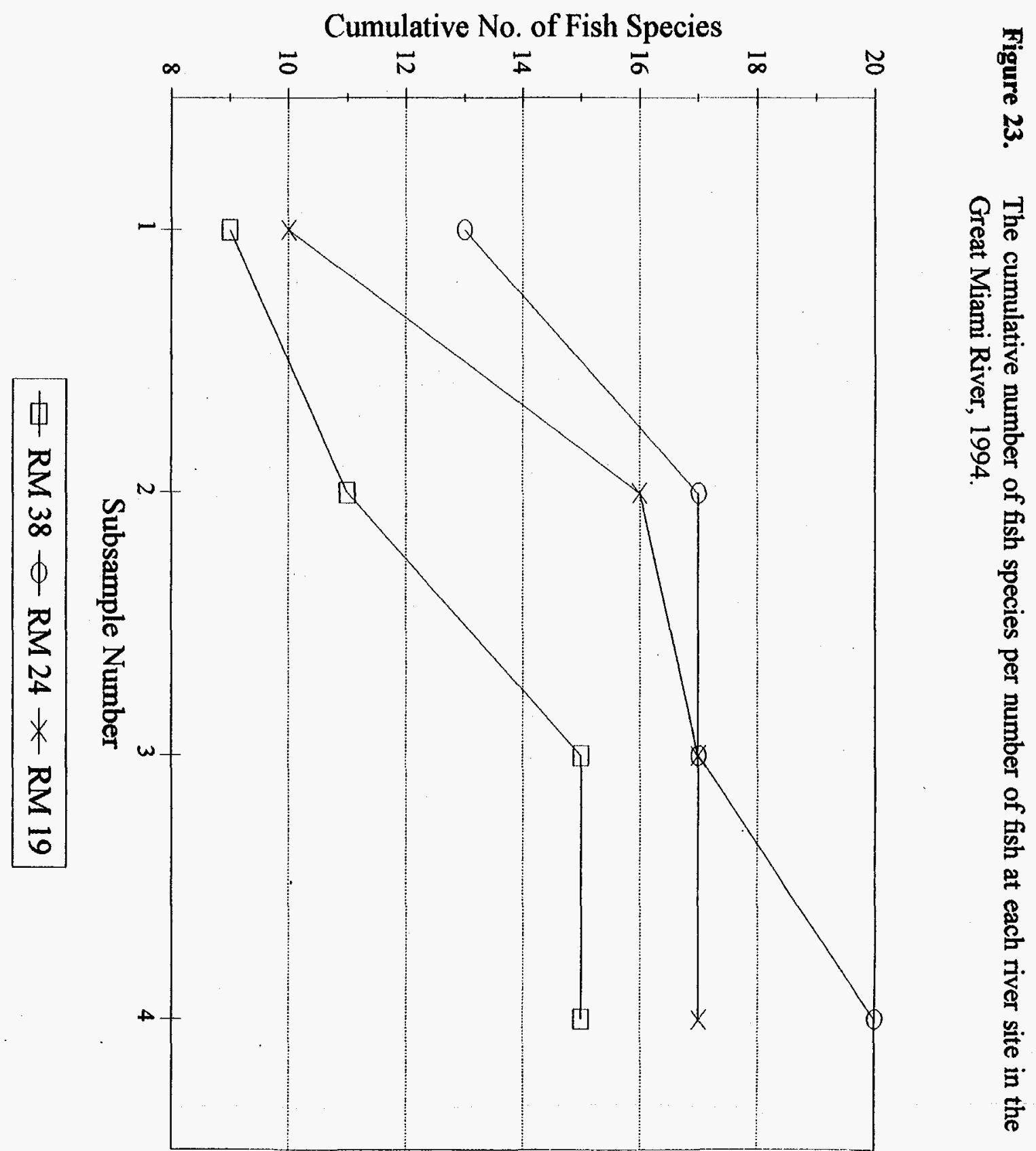


Figure 24. Detrended Correspondence Analysis of sites using fish species composition in the Great Miami River, 1994.

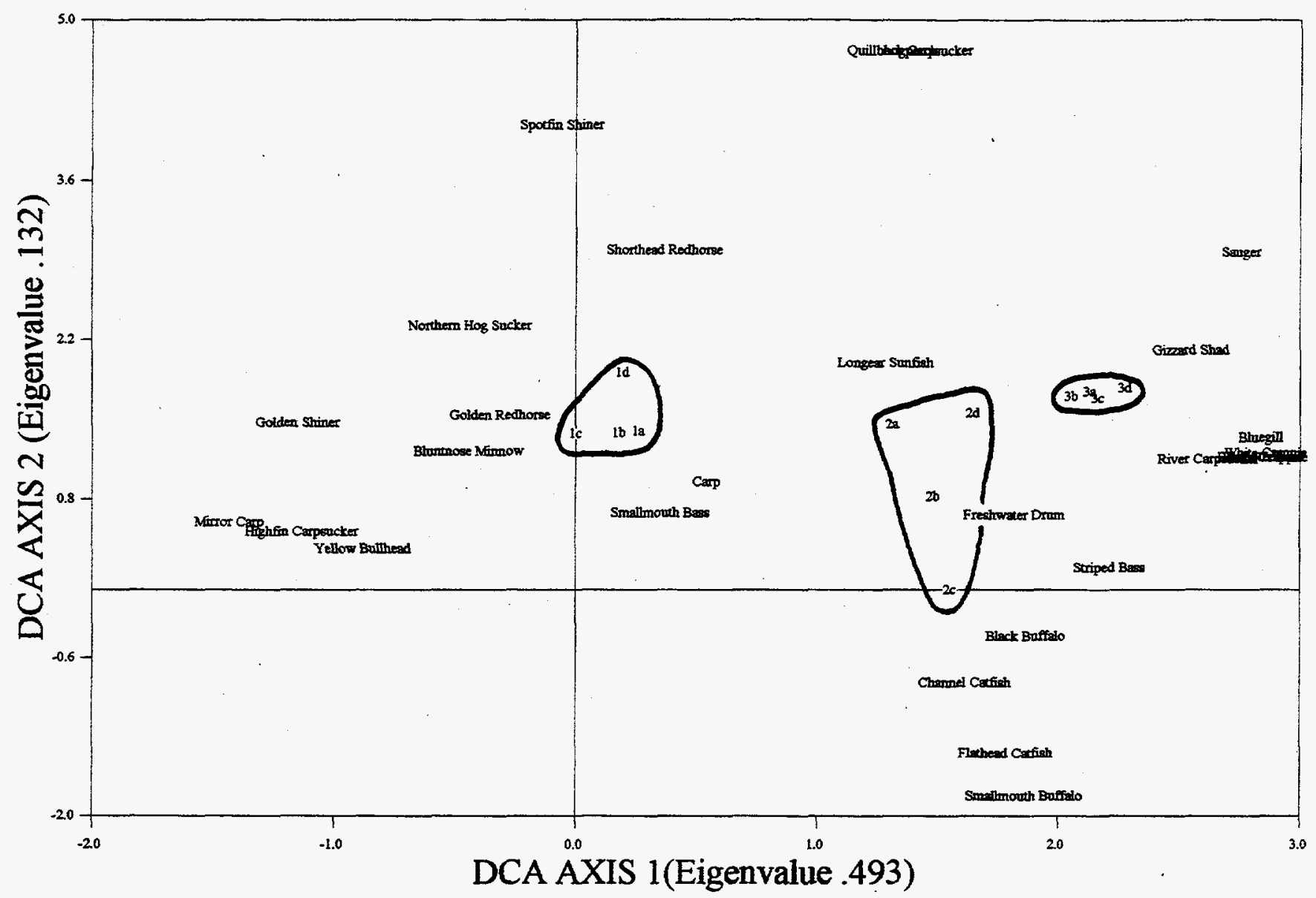

Note: The fish species have been iterated by the same ordination as the sites in order to show the relative relationship between species and sites. 
Table 1. Biotic and drainage data from OEPA for the Great Miami River for reference sites for comparison of other sites in the drainage area (data 1980 to 1986).

\begin{tabular}{|c|c|c|c|c|c|c|c|c|}
\hline GMR Tributaries & $\mathrm{RM}$ & Year & $\mathrm{D}$ & ECOREG & Drainage & Mean & Iwb & IBI \\
\hline Backpack Shocker & & & & & miles $^{\wedge} 2$ & Spp. \# & & \\
\hline Twin Creek & 0.2 & $\overline{1986}$ & A & $\overline{\mathrm{ECBP}}$ & 316.0 & 21.7 & 9.1 & $\overline{49}$ \\
\hline Fourmile Creek & 0.3 & 1980 & $\mathrm{~A}$ & ECBP & 315.0 & 18.7 & 8.8 & 49 \\
\hline Mad River & 1.2 & 1984 & A & ECBP & 655.0 & 17.0 & 8.7 & 3 \\
\hline Indian Creek & 4.1 & 1983 & D) & ECBP & 77.0 & 26.3 & 8.9 & 4 \\
\hline Whitewater River & 9.4 & 1985 & $\mathrm{D}$ & ECBP & 45.0 & 25.5 & 10.3 & 4 \\
\hline Stillwater River & 51.2 & 1983 & $\mathrm{D}$ & ECBP & 106.0 & 30.7 & 8.9 & 4 \\
\hline \multicolumn{9}{|l|}{ Boat Shocker } \\
\hline Loramie Creek & 0.1 & 1982 & A & ECBP & 201.0 & 17.0 & 8.6 & 4 \\
\hline Green Creek & 16.0 & 1982 & A & ECBP & 607.0 & 22.7 & 9.1 & 4 \\
\hline GMR Mainstem & 88.1 & 1980 & A & ECBP & 1150.0 & 20.7 & 8.3 & 3 \\
\hline GMR Mainstem & 91.0 & 1980 & A & ECBP & 1161.1 & 18.7 & 8.6 & 3 \\
\hline
\end{tabular}

Data from OEPA Ecological Assessment Section, 1988 Biological Criteria for the Protection of Aquatic Life: Vol. II: Users Manual for Biological Field Assessments of Ohio Surface Waters. Columbus, $\mathrm{OH}$. 
Table 2. Physical and chemical parameters for all sites sampled in the Great Miami River, 1994

\begin{tabular}{|l|l|c|c|c|c|c|c|}
\hline Parameters & Units & RM 42 & RM 38 & RM 27 & RM 24 & RM 19 & RM 12 \\
\hline \hline Date & September & 25 & 25 & 25 & 25 & 25 & 25 \\
\hline pH & units & 8.62 & 8.84 & 8.80 & 8.80 & 8.92 & 9.07 \\
\hline Temperature & degrees Centigrade & 18.6 & 18.0 & 18.8 & 19.0 & 19.5 & 20.7 \\
\hline Conductivity & micro Siemens & 1120 & 1020 & 1000 & 1000 & 1020 & 1010 \\
\hline Secchi Depth & meters & NA & 0.31 & NA & 0.28 & 0.30 & 0.23 \\
\hline Dissolved Oxygen & parts per million & 9.50 & 12.30 & 8.60 & 8.10 & 9.10 & 11.70 \\
\hline Phosphate & mg Phosphate/L & 1.490 & 1.554 & 1.436 & 1.392 & 1.123 & 0.069 \\
\hline Nitrate & mg Nitrate/L & 3.721 & 2.442 & 2.849 & 3.198 & 2.616 & 2.151 \\
\hline Ammonia & mg Ammonia/L & 0.092 & 0.022 & 0.016 & 0.043 & 0.033 & 0.011 \\
\hline Sulfate & mg Sulfate/L & 76.545 & 75.843 & 71.629 & 77.949 & 82.865 & 80.056 \\
\hline Total Chlorophyll & ug Chlorophyll/L & 31.731 & 46.475 & 42.799 & 44.887 & 56.524 & 54.502 \\
\hline
\end{tabular}

Note: Only RM 38, RM 24, and RM 19 were sampled for fish. 
Table 3. Common name, family, and numbers of fish collected by site in the Great Miami River, 25 and 26 September 1994.



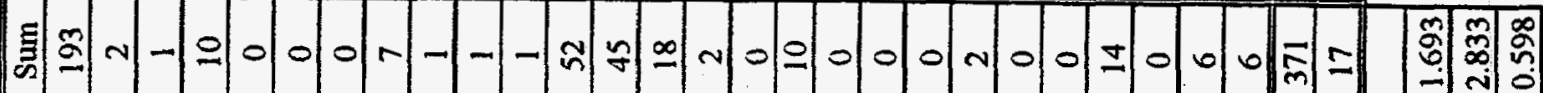

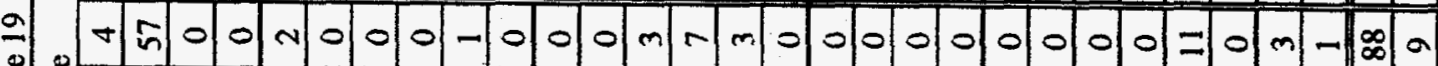

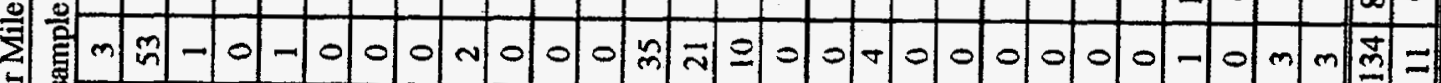

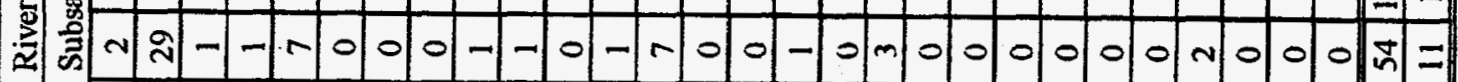

-

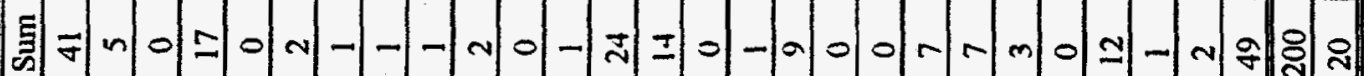



行

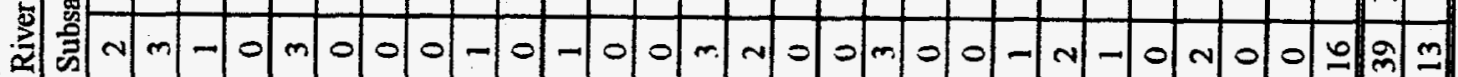

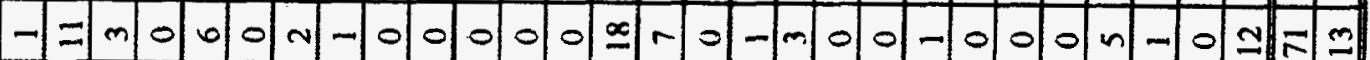

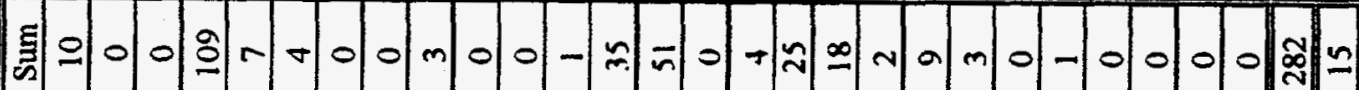

잉요잉

$\infty$ m $\sim$ N



:

-1000 -

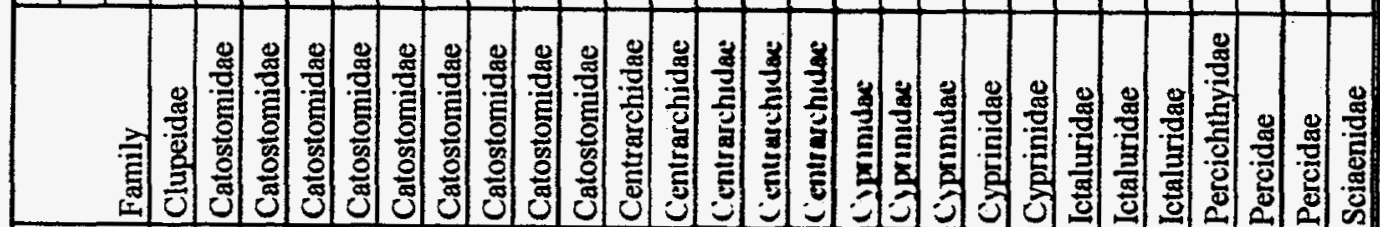

(

일

현

क :

䓪





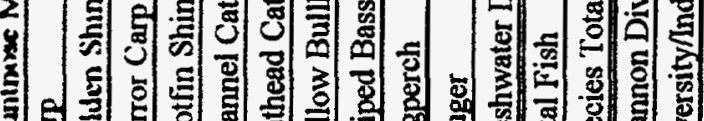

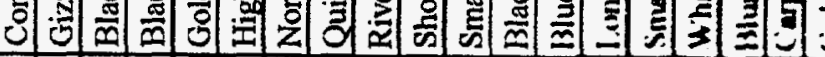
$*$

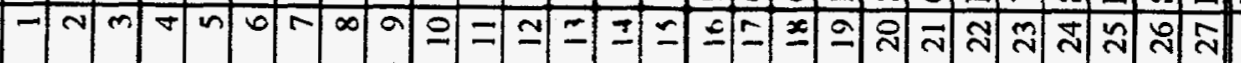




Table 5. The number of fish captured per hour and the number of species captured by river mile and by year from the Great Miami River, 1984 to 1994.

\begin{tabular}{|c|c|c|c|c||c|c|c|c|}
\hline & \multicolumn{9}{|c|}{ Number of Fish per Hour } & \multicolumn{3}{c|}{ Number of Species per Site } \\
\hline Yr/Site & RM 38 & RM 28 & RM 24 & RM 19 & RM 38 & RM 28 & RM 24 & RM 19 \\
\hline \hline 1984 & & & & & & 15 & 12 & 15 \\
\hline 1985 & & 104 & 84 & 314 & & 11 & 19 & 16 \\
\hline 1986 & & 98 & 79 & 266 & & 12 & 15 & 16 \\
\hline 1987 & & 73 & 75 & 102 & & 10 & 11 & 10 \\
\hline 1988 & & 146 & 3 & 154 & & 15 & 12 & 15 \\
\hline 1989 & & 120 & 69 & 136 & & 13 & 12 & 16 \\
\hline 1990 & & 65 & 60 & 119 & & 8 & 10 & 7 \\
\hline 1991 & 67 & 225 & 174 & 100 & 18 & 14 & 15 & 15 \\
\hline 1992 & 175 & 133 & 106 & 305 & 13 & 13 & 8 & 7 \\
\hline 1993 & 73 & & 35 & 90 & 13 & & 11 & 19 \\
\hline 1994 & 422 & & 300 & 426 & 15 & & 20 & 17 \\
\hline \hline Mean & 184.2 & 120.5 & 98.5 & 201.2 & 14.8 & 12.0 & 13.3 & 13.8 \\
\hline Coef.Var. & $90.2 \%$ & $41.9 \%$ & $85.0 \%$ & $58.3 \%$ & $16.0 \%$ & $19.5 \%$ & $27.9 \%$ & $29.2 \%$ \\
\hline
\end{tabular}

Table 6. Mean weight and length of fish electroshocked by year and by river mile in the Great Miami River, 1984 to 1994.

\begin{tabular}{|c|c|c|c|c||c|c|c|c|}
\hline & \multicolumn{3}{|c||}{ Weight of Fish (g) } & \multicolumn{3}{c|}{ Length of Fish (cm) } \\
\hline Yr/Site & RM 38 & RM 28 & RM 24 & RM 19 & RM 38 & RM 28 & RM 24 & RM 19 \\
\hline \hline 1984 & & & & & & & & \\
\hline 1985 & & 623 & 376 & 115 & & 23.8 & 26.3 & 18.5 \\
\hline 1986 & & 471 & 271 & 160 & & 30.5 & 23.3 & 23.8 \\
\hline 1987 & & 180 & 260 & 130 & & 26.0 & 28.0 & 23.0 \\
\hline 1988 & & 175 & 135 & 62 & & 25.0 & 23.5 & 14.5 \\
\hline 1989 & & 195 & 186 & 110 & & 21.8 & 21.0 & 17.4 \\
\hline 1990 & & 289 & 316 & 187 & & 30.3 & 29.4 & 23.5 \\
\hline 1991 & 140 & 166 & 157 & 56 & 16.9 & 21.8 & 17.6 & 14.8 \\
\hline 1992 & 39 & 345 & 150 & 53 & 10.3 & 25.7 & 21.9 & 16.6 \\
\hline 1993 & 244 & & 494 & 118 & 18.6 & & 31.2 & 16.6 \\
\hline 1994 & 176 & & 386 & 137 & 16.0 & & 24.8 & 14.9 \\
\hline \hline Mean & 149.9 & 305.5 & 273.1 & 112.8 & 15.4 & 25.6 & 24.7 & 18.4 \\
\hline Coef. Var. & $57.2 \%$ & $54.6 \%$ & $43.9 \%$ & $39.7 \%$ & $23.2 \%$ & $13.1 \%$ & $16.7 \%$ & $20.2 \%$ \\
\hline
\end{tabular}


Table 7. Species diversity and evenness using the Shannon Information Index (Hbar (log base 2)) by year and by river mile in the Great Miami River, 1984 to 1994.

\begin{tabular}{|c|c|c|c|c||c|c|c|c|}
\hline & \multicolumn{3}{|c||}{ H bar/Individual } & \multicolumn{4}{c|}{ Evenness } \\
\hline Yr/Site & RM 38 & RM 28 & RM 24 & RM 19 & RM 38 & RM 28 & RM 24 & RM 19 \\
\hline \hline 1984 & & 2.24 & 1.70 & 2.06 & & 0.58 & 0.48 & 0.53 \\
\hline 1985 & & 2.93 & 3.82 & 1.28 & & 0.85 & 0.90 & 0.32 \\
\hline 1986 & & 2.62 & 3.40 & 2.20 & & 0.73 & 0.87 & 0.55 \\
\hline 1987 & & 1.68 & 2.33 & 2.78 & & 0.51 & 0.89 & 0.40 \\
\hline 1988 & & 2.23 & 2.33 & 2.78 & & 0.57 & 0.75 & 0.71 \\
\hline 1989 & & 2.18 & 2.43 & 1.96 & & 0.59 & 0.68 & 0.49 \\
\hline 1990 & & 2.33 & 2.03 & 1.04 & & 0.78 & 0.61 & 0.37 \\
\hline 1991 & 3.11 & 2.10 & 2.82 & 1.75 & 0.45 & 0.47 & 0.58 & 0.32 \\
\hline 1992 & 2.55 & 2.49 & 1.68 & 0.49 & 0.69 & 0.67 & 0.56 & 0.18 \\
\hline 1993 & 1.80 & & 2.07 & 2.10 & 0.70 & & 0.86 & 0.71 \\
\hline 1994 & 1.94 & & 2.32 & +69 & 0.72 & & 0.77 & 0.60 \\
\hline \hline Mean & 2.35 & 2.31 & 2.45 & 2.10 & 0.64 & 0.64 & 0.72 & 0.47 \\
\hline Coef.Var. & $25.7 \%$ & $15.2 \%$ & $27.2 \%$ & $52.5 \%$ & $19.8 \%$ & $19.9 \%$ & $20.7 \%$ & $36.2 \%$ \\
\hline
\end{tabular}

Table 8. Community coefficients of species similarity between sites in the Great Miami River, 1994.

\begin{tabular}{|c||c|c|c|}
\hline RM & 38 & 24 & 19 \\
\hline \hline 38 & 1 & 0.63 & 0.50 \\
\hline 24 & 0.63 & 1 & 0.76 \\
\hline 19 & 0.50 & 0.76 & 1 \\
\hline
\end{tabular}


Table 9. Weight frequency distribution of fish electroshocked in the Great Miami River, 25 and 26 September 1994.

\begin{tabular}{|c|c|c|c|c|}
\hline \multicolumn{5}{|c|}{ Weight Frequency Distribution } \\
\hline Grams & Total & RM 38 & RM 24 & RM 19 \\
\hline 0 & 4 & 1 & $\overline{2}$ & 1 \\
\hline 25 & 422 & 154 & 42 & 226 \\
\hline 50 & 78 & 28 & 20 & 30 \\
\hline 75 & 54 & 20 & 4 & 30 \\
\hline 100 & 33 & 8 & 6 & 19 \\
\hline 125 & 26 & 8 & 10 & 8 \\
\hline 150 & 16) & 0 & 11 & 5 \\
\hline 175 & 22 & 3 & 7 & 12 \\
\hline 200 & 19 & 4 & 12 & 3 \\
\hline 225 & 19 & 7 & 6 & 6 \\
\hline 250 & 15 & 8 & 5 & $\overline{2}$ \\
\hline 275 & 11 & 21 & 8 & 1 \\
\hline 300 & 10 & 2 & 6 & 2 \\
\hline 325 & 8 & $2 \mid$ & 5 & 1 \\
\hline 350 & 8 & 31 & 4 & 1 \\
\hline 375 & 4 & 3 & 1 & 0 \\
\hline 400 & 4 & 1 & 1 & 2 \\
\hline 425 & 6 & 1 & 5 & 0 \\
\hline 450 & 5 & 0 & 4 & 1 \\
\hline 475 & 6 & of & 5 & 1 \\
\hline 500 & 5 & 3 & 1 & 1 \\
\hline 525 & 4 & 0) & 4 & 0 \\
\hline 550 & 3 & 2 & 1 & 0 \\
\hline 575 & 1 & 01 & 1 & 0 \\
\hline 600 & 5 & 4 & 1 & 0 \\
\hline 625 & 3 & of & 1 & 2 \\
\hline 650 & 2 & 2 & 0 & 0 \\
\hline 675 & 3 & 2 & 1 & 0 \\
\hline 700 & 1 & of & 0 & 1 \\
\hline 725 & 0 & 0 & $\overline{0}$ & 0 \\
\hline 750 & 1 & 1 & 0 & 0 \\
\hline 775 & 2 & 0 & 1 & 1 \\
\hline 800 & 2 & 1 & 1 & 0 \\
\hline 825 & 3 & 1 & 1 & 1 \\
\hline 850 & 3 & 우 & 2 & 1 \\
\hline 875 & 1 & 0 & $\overline{0}$ & 1 \\
\hline 900 & 1 & 의 & 0 & 1 \\
\hline 925 & 2 & 인 & 2 & 0 \\
\hline 950 & 1 & 0 & 0 & 1 \\
\hline 975 & 1 & 0 & 0 & 1 \\
\hline 1000 & 1 & 0 & 1 & 0 \\
\hline 1500 & 18 & 4 & 8 & 6 \\
\hline 2000 & 9 & 3 & 5 & 1 \\
\hline 2500 & 5 & 3 & 2 & 0 \\
\hline 3500 & 2 & 1 & 1 & 0 \\
\hline 4500 & 2 & 0 & 1 & $\overline{1}$ \\
\hline 5500 & 1 & 0 & 1 & 0 \\
\hline 6500 & 1 & 0 & 0 & 1 \\
\hline SUM & 853 & 282 & 200 & 371 \\
\hline
\end{tabular}


Table 10. Length frequency distribution of fish electroshocked in the Great Miami River, 25 and 26 September 1994.

\begin{tabular}{|c|c|c|c|c|}
\hline \multicolumn{5}{|c|}{ Length Frequency Distribution } \\
\hline $\mathrm{cm}$ & Total & RM 38 & RM 24 & RM 19 \\
\hline 0 & 0 & 0 & 0 & 0 \\
\hline 2 & 0 & 0 & 0 & 0 \\
\hline 4 & $\overline{4}$ & 3 & 0 & $\overline{1}$ \\
\hline 6 & 46 & 17 & 2 & 27 \\
\hline 8 & 115 & 50 & 23 & 42 \\
\hline 10 & 120 & 66 & 5 & 49 \\
\hline 12 & 124 & 24 & 11 & 89 \\
\hline 14 & 58 & 10 & 11 & 37 \\
\hline 16 & 51 & 23 & 11 & 17 \\
\hline 18 & 27 & 11 & 1 & 15 \\
\hline 20 & 31 & 9 & 3 & 19 \\
\hline 22 & 24 & 4 & 8 & 12 \\
\hline 24 & 27 & 1 & 18 & 8 \\
\hline 26 & 41 & 11 & 14 & 16 \\
\hline 28 & 43 & 8 & 24 & 11 \\
\hline 30 & 24 & 9 & 13 & 2 \\
\hline 32 & 17 & 7 & 7 & 3 \\
\hline 34 & 15 & 3 & 10 & 2 \\
\hline 36 & 12 & 5 & 6 & 1 \\
\hline 38 & 12 & 5 & 4 & 3 \\
\hline 40 & 12 & 4 & 5 & 3 \\
\hline 42 & 5 & 0 & 3 & 2 \\
\hline 44 & 10 & 0 & 5 & 5 \\
\hline 46 & 6 & 3 & 2 & 1 \\
\hline 48 & 4 & 0 & 2 & 2 \\
\hline 50 & 3 & 0 & 3 & 0 \\
\hline 52 & 5 & 3 & 2 & 0 \\
\hline 54 & 3 & 1 & 2 & 0 \\
\hline 56 & 1 & 0 & 0 & 1 \\
\hline 58 & 5 & 4 & 1 & 0 \\
\hline 60 & 3 & 0 & 2 & 1 \\
\hline 70 & 3 & 0 & 2 & 1 \\
\hline 80 & 2 & 1 & 0 & 1 \\
\hline SUM & 853 & 282 & 200 & 371 \\
\hline
\end{tabular}


Appendix A. Listing of common names, species, and families in the Great Miami River, 1994.

\begin{tabular}{|r|l|l|l|}
\hline$\#$ & Common Name & Species & Family \\
\hline \hline 1 & Gizzard Shad & Dorosoma cepedianum & Clupeidae \\
\hline 2 & Bluntnose Minnow & Pimephales notatus & Cyprinidae \\
\hline 3 & Carp & Cyprinus carpio sp. & Cyprinidae \\
\hline 4 & Golden Shiner & Notemigonus crysoleucas & Cyprinidae \\
\hline 5 & Mirror Carp & Cyprinus carpio & Cyprinidae \\
\hline 6 & Spotfin Shiner & Cyprinella spilopterus & Cyprinidae \\
\hline 7 & Black Buffalo & Ictiobus niger & Catostomidae \\
\hline 8 & Black Redhorse & Moxostoma duquesnei & Catostomidae \\
\hline 9 & Golden Redhorse & Moxostoma erythrurum & Catostomidae \\
\hline 10 & Highfin Carpsucker & Carpiodes velifer & Catostomidae \\
\hline 11 & Northern Hog Sucker & Hypentelium nigricans & Catostomidae \\
\hline 12 & Quillback & Carpiodes cyprinus & Catostomidae \\
\hline 13 & River Carpsucker & Carpiodes carpio & Catostomidae \\
\hline 14 & Shorthead Redhorse & Moxostoma macrolepidotum & Catostomidae \\
\hline 15 & Smallmouth Buffalo & Ictibus bubalus & Catostomidae \\
\hline 16 & Channel Catfish & Ictalurus punctatus & Ictaluridae \\
\hline 17 & Flathead Catfish & Ictalurus olivaris & Ictaluridae \\
\hline 18 & Yellow Bullhead & Ictalurus natalis & Ictaluridae \\
\hline 19 & Striped Bass & Morone saxatilis & Percichthyidae \\
\hline 20 & Black Crappie & Pomoxis nigromaculatus & Centrarchidae \\
\hline 21 & Bluegill & Lepomis macrochirus & Centrarchidae \\
\hline 22 & Longear Sunfish & Lepomis megalotis & Centrarchidae \\
\hline 23 & Smallmouth Bass & Micropterus dolomieui & Centrarchidae \\
\hline 24 & White Crappie & Pomoxis annularis & Centrarchidae \\
\hline 25 & Logperch & Percina caprodes & Percidae \\
\hline 26 & Sauger & Stizostedion canadense & Percidae \\
\hline 27 & Freshwater Drum & Aploinotus grunniens & Sciaenidae \\
\hline & & \\
\hline
\end{tabular}


Appendix B. Listing of the lengths and weights of fish captured at River Mile 38, 1994.

\begin{tabular}{|c|c|c|c|c|c|c|c|c|c|}
\hline$\#$ & $\begin{array}{c}\text { Sub. } \\
\#\end{array}$ & No. & Common Name & Family & $\begin{array}{l}\text { Length } \\
(\mathrm{cm})\end{array}$ & $\begin{array}{c}\text { Weight } \\
\text { (g) }\end{array}$ & $\begin{array}{c}\text { Bag } \\
\#\end{array}$ & $\begin{array}{c}\text { Bag Wt } \\
\text { (g) }\end{array}$ & Notes \\
\hline 1 & 1 & 1 & carp & Cyprinidae & 58 & 2622 & 103 & 544 & dupl wt $=606$ \\
\hline 2 & 1 & 2 & carp & Cyprinidae & 50.1 & 1546 & 102 & 694 & \\
\hline 3 & 1 & 3 & carp & Cyprinidae & 18.7 & 102 & 101 & 224 & \\
\hline 4 & 1 & 4 & carp & Cyprinidae & 18.5 & 84 & 101 & 224 & \\
\hline 5 & 1 & 5 & carp & Cyprinidae & 15.9 & 64 & 101 & 224 & \\
\hline 6 & 1 & 6 & carp & Cyprinidae & 15 & 52 & 101 & 224 & \\
\hline 7 & 1 & 7 & carp & Cyprinidae & 15 & 56 & 101 & 224 & \\
\hline 8 & 1 & 8 & carp & Cyprinidae & 15.3 & 54 & 101 & 224 & \\
\hline 9 & 1 & 1 & gizzard shad & Clupeidae & 36 & 664 & 104 & 420 & \\
\hline 10 & 1 & 2 & gizzard shad & Clupeidae & 28.8 & 270 & 105 & 258 & \\
\hline 11 & 1 & 3 & gizzard shad & Clupeidae & 26.7 & 204 & 105 & 258 & \\
\hline 12 & 1 & 4 & gizzard shad & Clupeidae & 25.1 & 162 & 106 & 208 & \\
\hline 13 & 1 & 5 & gizzard shad & Clupeidae & 26.8 & 202 & 106 & 208 & \\
\hline 14 & 1 & 6 & gizzard shad & Clupeidae & 24.6 & 156 & 107 & 206 & \\
\hline 15 & 1 & 7 & gizzard shad & Clupeidae & 24.7 & 164 & 107 & 206 & \\
\hline 16 & 1 & 1 & channel catfish & Ictaluridae & 38 & 496 & 108 & 362 & \\
\hline 17 & 1 & 1 & yellow bullhead & Ictaluridae & 32.5 & 358 & 108 & 362 & \\
\hline 18 & 1 & 1 & highfin carpsucker & Catostomidae & 37.1 & 674 & 109 & 618 & \\
\hline 19 & 1 & 2 & highfin carpsucker & Catostomidae & 34 & 528 & 109 & 618 & \\
\hline 20 & 1 & 3 & highfin carpsucker & Catostomidae & 32.9 & 490 & 110 & 432 & \\
\hline 21 & 1 & 4 & highfin carpsucker & Catostomidae & 30.5 & 360 & 110 & 432 & \\
\hline 22 & 1 & 1 & smallmouth bass & Centrarchidae & 15.3 & 48 & 111 & 458 & \\
\hline 23 & 1 & 2 & smallmouth bass & Centrarchidae & 12.6 & 26 & 111 & 458 & \\
\hline 24 & $\overline{1}$ & 3 & smallmouth bass & Centrarchidae & 9 & 8 & 111 & 458 & \\
\hline 25 & 1 & 1 & golden shiner & Cyprinidae & 10 & 10.2 & 112 & 266 & \\
\hline 26 & 1 & 2 & golden shiner & Cyprinidae & 9.6 & 8.8 & 112 & 266 & \\
\hline 27 & 1 & 3 & golden shiner & Cyprinidae & 8.8 & 7.3 & 112 & 266 & \\
\hline 28 & 1 & 4 & golden shiner & Cyprinidae & 9 & 6.4 & 112 & 266 & \\
\hline 29 & 1 & 5 & golden shiner & Cyprinidae & 8.4 & 5 & 112 & 266 & \\
\hline 30 & 1 & 6 & golden shiner & Cyprinidae & 7.7 & 4.5 & 112 & 266 & \\
\hline 31 & 1 & 1 & golden redhorse & Catostomidae & 40 & 790 & 113 & 358 & \\
\hline 32 & 1 & 2 & golden redhorse & Catostomidae & 35.9 & 538 & 114 & 248 & \\
\hline 33 & 1 & 3 & golden redhorse & Catostomidae & 31.2 & 362 & 115 & 398 & \\
\hline 34 & 1 & 4 & golden redhorse & Catostomidae & 30 & 334 & 115 & 398 & \\
\hline 35 & 1 & 5 & golden redhorse & Catostomidae & 31.1 & 336 & 116 & 556 & \\
\hline 36 & $\overline{1}$ & 6 & golden redhorse & Catostomidae & 30.5 & 334 & 116 & 556 & \\
\hline 37 & 1 & 7 & golden redhorse & Catostomidae & 27.4 & 244 & 116 & 556 & \\
\hline 38 & 1 & 8 & golden redhorse & Catostomidae & 29.3 & 290 & 117 & 672 & \\
\hline 39 & 1 & 9 & golden redhorse & Catostomidae & 27.7 & 238 & 117 & 672 & \\
\hline 40 & 1 & 10 & golden redhorse & Catostomidae & 28.3 & 282 & 117 & 672 & \\
\hline 41 & 1 & 11 & golden redhorse & Catostomidae & 29.6 & 302 & 117 & 672 & \\
\hline 42 & 1 & 12 & golden redhorse & Catostomidae & 28.2 & 246 & 118 & 262 & \\
\hline 43 & 1 & 13 & golden redhorse & Catostomidae & 21 & 94 & 118 & 262 & \\
\hline 44 & 1 & 14 & golden redhorse & Catostomidae & 9.6 & 9.9 & 118 & 262 & \\
\hline 45 & 1 & 15 & golden redhorse & Catostomidae & 10 & 11.4 & 118 & 262 & \\
\hline
\end{tabular}




\begin{tabular}{|c|c|c|c|c|c|c|c|c|c|}
\hline$\#$ & $\begin{array}{c}\text { Sub. } \\
\#\end{array}$ & No. & Common Name & Family & $\begin{array}{l}\text { Length } \\
(\mathrm{cm})\end{array}$ & $\begin{array}{l}\text { Weight } \\
\text { (g) }\end{array}$ & $\begin{array}{c}\text { Bag } \\
\#\end{array}$ & $\begin{array}{c}\text { Bag Wt } \\
\text { (g) }\end{array}$ & Notes \\
\hline 46 & 1 & 16 & golden redhorse & Catostomidae & 9.3 & 9 & 118 & 262 & \\
\hline 47 & 1 & 17 & golden redhorse & Catostomidae & 9.4 & 9.9 & 118 & 262 & \\
\hline 48 & 1 & 18 & golden redhorse & Catostomidae & 9.9 & 8.8 & 118 & 262 & \\
\hline 49 & 1 & 19 & golden redhorse & Catostomidae & 9.5 & 8.5 & 118 & 262 & \\
\hline 50 & 1 & 20 & golden redhorse & Catostomidae & 8.4 & 6.7 & 118 & 262 & \\
\hline 51 & 1 & 21 & golden redhorse & Catostomidae & 8 & 6.3 & 118 & 262 & \\
\hline 52 & 1 & 1 & longear sunfish & Centrarchidae & 11.5 & 35.2 & 119 & 369 & \\
\hline 53 & 1 & 2 & longear sunfish & Centrarchidae & 11 & 31 & 119 & 369 & \\
\hline 54 & 1 & 3 & longear sunfish & Centrarchidae & 9.4 & 17.1 & 119 & 369 & \\
\hline 55 & 1 & 4 & longear sunfish & Centrarchidae & 6.8 & 6.8 & 119 & 369 & \\
\hline 56 & 1 & 5 & longear sunfish & Centrarchidae & 5.9 & 4.5 & 119 & 369 & \\
\hline 57 & 1 & 6 & longear sunfish & Centrarchidae & 5.3 & 4 & 119 & 369 & \\
\hline 58 & 1 & 7 & longear sunfish & Centrarchidae & 5.3 & 3.5 & 119 & 369 & \\
\hline 59 & 2 & 1 & carp & Cyprinidae & 75.9 & 6378 & 120 & 2220 & \\
\hline 60 & 2 & 2 & carp & Cyprinidae & 15 & 52.3 & 121 & 288 & \\
\hline 61 & 2 & 3 & carp & Cyprinidae & 19.4 & 113 & 121 & 288 & \\
\hline 62 & 2 & 4 & carp & Cyprinidae & 16.6 & 66 & 121 & 288 & \\
\hline 63 & 2 & 5 & carp & Cyprinidae & 16.4 & 66 & 121 & 288 & \\
\hline 64 & 2 & 6 & carp & Cyprinidae & 15.4 & 54 & 121 & 288 & \\
\hline 65 & 2 & 7 & carp & Cyprinidae & 14.7 & 52 & 121 & 288 & \\
\hline 66 & 2 & 8 & carp & Cyprinidae & 13.9 & 50 & 121 & 288 & \\
\hline 67 & 2 & 1 & mirror carp & Cyprinidae & 13.5 & 36 & 121 & 288 & ununiform scales \\
\hline 68 & 2 & 1 & channel catfish & Ictaluridae & 52.6 & 1204 & 124 & 400 & \\
\hline 69 & 2 & 2 & channel catfish & Ictaluridae & 31.5 & 234 & 124 & 400 & \\
\hline 70 & $\overline{2}$ & 1 & smallmouth bass & Centrarchidae & 30.2 & 382 & 123 & 226 & \\
\hline 71 & 2 & 2 & smallmouth bass & Centrarchidae & 13.2 & 31 & 111 & 458 & \\
\hline 72 & 2 & 3 & smallmouth bass & Centrarchidae & 11.7 & 18.7 & 111 & 458 & \\
\hline 73 & 2 & 4 & smallmouth bass & Centrarchidae & 11.3 & 20.8 & 111 & 458 & \\
\hline 74 & 2 & 5 & smallmouth bass & Centrarchidae & 11.6 & 20.5 & 111 & 458 & \\
\hline 75 & 2 & 6 & smallmouth bass & Centrarchidae & 12.2 & 23.8 & 111 & 458 & \\
\hline 76 & 2 & 7 & smallmouth bass & Centrarchidae & 10.6 & 14.9 & 111 & 458 & \\
\hline 77 & 2 & 8 & smallmouth bass & Centrarchidae & 9.5 & 12.3 & 111 & 458 & \\
\hline 78 & 2 & 9 & smallmouth bass & Centrarchidae & 10.4 & 14.4 & 111 & 458 & \\
\hline 79 & 2 & 10 & smallmouth bass & Centrarchidae & 9.2 & 11 & 111 & 458 & \\
\hline 80 & 2 & 11 & smallmouth bass & Centrarchidae & 9.7 & 12.3 & 111 & 458 & \\
\hline 81 & 2 & 12 & smallmouth bass & Centrarchidae & 8.5 & 8.1 & 111 & 458 & \\
\hline 82 & 2 & 13 & smallmouth bass & Centrarchidae & 7.5 & 6 & 111 & 458 & \\
\hline 83 & 2 & 14 & smallmouth bass & Centrarchidae & 7.7 & 5 & 111 & 458 & \\
\hline 84 & 2 & 15 & smallmouth bass & Centrarchidae & 7.2 & $\overline{4.8}$ & 111 & 458 & \\
\hline 85 & 2 & 16 & smallmouth bass & Centrarchidae & 6.5 & 3.7 & 111 & 458 & \\
\hline 86 & 2 & 17 & smallmouth bass & Centrarchidae & 8 & 6.4 & 111 & 458 & \\
\hline 87 & 2 & 18 & smallmouth bass & Centrarchidae & 6 & 3 & 111 & 458 & \\
\hline 88 & 2 & 1 & golden redhorse & Catostomidae & 37.5 & 584 & 122 & 448 & \\
\hline 89 & 2 & 2 & golden redhorse & Catostomidae & 28.4 & 238 & 122 & 448 & \\
\hline 90 & 2 & 3 & golden redhorse & Catostomidae & 26 & 190 & 125 & 472 & \\
\hline 91 & 2 & 4 & golden redhorse & Catostomidae & 25.5 & 190 & 125 & 472 & \\
\hline 92 & 2 & 5 & golden redhorse & Catostomidae & 21.4 & 102 & 125 & 472 & \\
\hline 93 & 2 & 6 & golden redhorse & Catostomidae & 17.4 & 56 & 125 & 472 & \\
\hline 94 & 2 & 7 & golden redhorse & Catostomidae & 9 & 7.7 & 125 & 472 & \\
\hline
\end{tabular}




\begin{tabular}{|c|c|c|c|c|c|c|c|c|c|}
\hline \# & $\begin{array}{c}\text { Sub. } \\
\#\end{array}$ & No. & Common Name & Family & $\begin{array}{c}\text { Length } \\
\text { (cm) }\end{array}$ & $\begin{array}{l}\text { Weight } \\
\text { (g) }\end{array}$ & $\begin{array}{c}\text { Bag } \\
\#\end{array}$ & $\begin{array}{l}\text { Bag Wt } \\
\text { (g) }\end{array}$ & Notes \\
\hline 95 & 2 & 8 & golden redhorse & Catostomidae & 8.1 & 5.7 & 125 & 472 & \\
\hline 96 & 2 & 9 & golden redhorse & Catostomidae & 7 & 3.8 & 125 & 472 & \\
\hline 97 & 2 & 10 & golden redhorse & Catostomidae & 7.2 & 4.4 & 125 & 472 & \\
\hline 98 & 2 & 11 & golden redhorse & Catostomidae & 8.3 & 6.7 & 125 & 472 & \\
\hline 99 & 2 & 12 & golden redhorse & Catostomidae & 7.2 & 4.1 & 125 & 472 & \\
\hline 100 & 2 & 13 & golden redhorse & Catostomidae & 8.8 & 7.4 & 125 & 472 & \\
\hline 101 & 2 & 14 & golden redhorse & Catostomidae & 9.2 & 8 & 125 & 472 & \\
\hline 102 & 2 & 15 & golden redhorse & Catostomidae & 10.7 & 10.3 & 125 & 472 & \\
\hline 103 & 2 & 16 & golden redhorse & Catostomidae & 8 & 5.6 & 125 & 472 & \\
\hline 104 & 2 & 17 & golden redhorse & Catostomidae & $\overline{7.2}$ & 4.2 & 125 & 472 & \\
\hline 105 & 2 & 18 & golden redhorse & Catostomidae & 9 & 7.8 & 125 & 472 & \\
\hline 106 & 2 & 19 & golden redhorse & Catostomidae & 8.2 & 6.6 & 125 & 472 & \\
\hline 107 & 2 & 20 & golden redhorse & Catostomidae & 7.3 & 4.4 & 125 & 472 & \\
\hline 108 & 2 & 21 & golden redhorse & Catostomidae & 8.3 & 6 & 125 & 472 & \\
\hline 109 & 2 & 22 & golden redhorse & Catostomidae & 9.1 & 7.5 & 125 & 472 & \\
\hline 110 & 2 & 23 & golden redhorse & Catostomidae & 7 & 4 & 125 & 472 & \\
\hline 111 & 2 & 24 & golden redhorse & Catostomidae & 7.2 & 4.6 & 125 & 472 & \\
\hline 112 & 2 & 25 & golden redhorse & Catostomidae & 7.2 & 4.5 & 125 & 472 & \\
\hline 113 & 2 & 26 & golden redhorse & Catostomidae & 7.2 & 5.5 & 125 & 472 & \\
\hline 114 & 2 & 27 & golden redhorse & Catostomidae & 8.5 & 6.4 & 125 & 472 & \\
\hline 115 & 2 & 28 & golden redhorse & Catostomidae & 8 & 5.8 & 125 & 472 & \\
\hline 116 & 2 & 29 & golden redhorse & Catostomidae & 8.9 & 7.3 & 125 & 472 & \\
\hline 117 & 2 & 30 & golden redhorse & Catostomidae & 8 & 5.4 & 125 & 472 & \\
\hline 118 & 2 & 31 & golden redhorse & Catostomidae & 9.2 & 8.9 & 125 & 472 & \\
\hline 119 & 2 & 32 & golden redhorse & Catostomidae & 8.6 & 7.1 & 125 & 472 & \\
\hline 120 & 2 & 33 & golden redhorse & Catostomidae & 8.6 & 7.4 & 125 & 472 & \\
\hline 121 & 2 & 34 & golden redhorse & Catostomidae & 7.7 & 5 & 125 & 472 & \\
\hline 122 & 2 & 35 & golden redhorse & Catostomidae & 8.5 & 6.6 & 125 & 472 & \\
\hline 123 & 2 & 36 & golden redhorse & Catostomidae & 8.5 & 7.2 & 125 & 472 & \\
\hline 124 & 2 & 37 & golden redhorse & Catostomidae & 8.9 & 8.5 & 125 & 472 & \\
\hline 125 & 2 & 38 & golden redhorse & Catostomidae & 8.5 & 6.4 & 125 & 472 & \\
\hline 126 & 2 & 39 & golden redhorse & Catostomidae & 8.5 & 7.4 & 125 & 472 & \\
\hline 127 & 2 & 40 & golden redhorse & Catostomidae & 8.2 & 5.8 & 125 & 472 & \\
\hline 128 & 2 & 41 & golden redhorse & Catostomidae & 8.7 & 7.7 & 125 & 472 & \\
\hline 129 & 2 & 42 & golden redhorse & Catostomidae & 9.6 & 9.2 & 125 & 472 & \\
\hline 130 & 2 & 43 & golden redhorse & Catostomidae & 8.8 & 7.3 & 125 & 472 & \\
\hline 131 & 2 & 44 & golden redhorse & Catostomidae & 7 & 4 & 125 & 472 & \\
\hline 132 & 2 & 45 & golden redhorse & Catostomidae & 6.8 & 3.6 & 125 & 472 & \\
\hline 133 & 2 & 46 & golden redhorse & Catostomidae & 8 & 5.4 & 125 & 472 & \\
\hline 134 & 2 & 47 & golden redhorse & Catostomidae & 8 & 5.9 & 125 & 472 & \\
\hline 135 & 2 & 48 & golden redhorse & Catostomidae & 8.4 & 6 & 125 & 472 & \\
\hline 136 & 2 & 49 & golden redhorse & Catostomidae & 9.7 & 9.6 & 125 & 472 & \\
\hline 137 & 2 & 1 & golden shiner & Cyprinidae & 7.9 & 4.7 & 112 & 266 & \\
\hline 138 & 2 & 2 & golden shiner & Cyprinidae & 8.9 & 6.8 & 112 & 266 & \\
\hline 139 & 2 & 3 & golden shiner & Cyprinidae & 7 & 3.3 & 112 & 266 & \\
\hline 140 & 2 & 4 & golden shiner & Cyprinidae & 7 & 3.4 & 112 & 266 & \\
\hline 141 & 2 & 1 & longear sunfish & Centrarchidae & 12 & 34.6 & 119 & 369 & \\
\hline 142 & 2 & 2 & longear sunfish & Centrarchidae & 8.7 & 11.9 & 119 & 369 & \\
\hline 143 & 2 & 3 & longear sunfish & Centrarchidae & 7.9 & 10.7 & 119 & 369 & \\
\hline
\end{tabular}




\begin{tabular}{|c|c|c|c|c|c|c|c|c|c|}
\hline$\#$ & $\begin{array}{c}\text { Sub. } \\
\#\end{array}$ & No. & Common Name & Family & $\begin{array}{l}\text { Length } \\
(\mathrm{cm})\end{array}$ & $\begin{array}{c}\text { Weight } \\
\text { (g) }\end{array}$ & $\begin{array}{c}\text { Bag } \\
\#\end{array}$ & $\begin{array}{c}\text { Bag Wt } \\
\text { (g) }\end{array}$ & Notes \\
\hline$\overline{144}$ & $\overline{2}$ & $\overline{4}$ & longear sunfish & Centrarchidae & 8.6 & 12.8 & 119 & 369 & \\
\hline 145 & 2 & 5 & longear sunfish & Centrarchidae & 7 & 8.1 & 119 & 369 & \\
\hline 146 & 2 & 6 & longear sunfish & Centrarchidae & 7.6 & 9.2 & 119 & 369 & \\
\hline 147 & 2 & 7 & longear sunfish & Centrarchidae & 6.5 & 5.8 & 119 & 369 & \\
\hline 148 & 2 & 8 & longear sunfish & Centrarchidae & 6.2 & 5.2 & 119 & 369 & \\
\hline 149 & 2 & 9 & longear sunfish & Centrarchidae & 6.6 & 6.7 & 119 & 369 & \\
\hline 150 & 2 & 10 & longear sunfish & Centrarchidae & 7.4 & 8.3 & 119 & 369 & \\
\hline 151 & 2 & 11 & longear sunfish & Centrarchidae & 6.3 & 5.1 & 119 & 369 & \\
\hline 152 & 2 & 12 & longear sunfish & Centrarchidae & 6.5 & 5.1 & 119 & 369 & \\
\hline 153 & 2 & 13 & longear sunfish & Centrarchidae & 5.5 & 3.9 & 119 & 369 & \\
\hline 154 & 2 & 14 & longear sunfish & Centrarchidae & 5.5 & 3.2 & 119 & 369 & \\
\hline 155 & 2 & 15 & longear sunfish & Centrarchidae & 5.8 & 3.7 & 119 & 369 & \\
\hline 156 & 2 & 16 & longear sunfish & Centrarchicae & 4 & 1.5 & 119 & 369 & \\
\hline 157 & 2 & 17 & longear sunfish & Centrarchidae & 5.8 & 4 & 119 & 369 & \\
\hline 158 & 2 & 18 & longear sunfish & Centrarchidae & 5.6 & 3.7 & 119 & 369 & \\
\hline 159 & 2 & 19 & longear sunfish & Centrarchidae & 6 & 4.9 & 119 & 369 & \\
\hline 160 & 2 & 20 & longear sunfish & Centrarchidae & 5.3 & 3.3 & 119 & 369 & \\
\hline 161 & 2 & 21 & longear sunfish & Centrarchidae & +.7 & 2.2 & 119 & 369 & \\
\hline 162 & 2 & 22 & longear sunfish & Centrarchidae & 3.1 & 0.6 & 119 & 369 & \\
\hline 163 & 2 & 1 & bluntnose minnow & Cyprinidae & +.7 & 0.9 & 112 & 266 & \\
\hline 164 & 2 & 2 & bluntnose minnow & Cyprinidae & 5.1 & 1.2 & 112 & 266 & \\
\hline 165 & 2 & 3 & bluntnose minnow & Cyprinidae & +.2 & 0.7 & 112 & 266 & \\
\hline 166 & 2 & 4 & bluntnose minnow & Cyprinidae & 3.1 & 0.5 & 112 & 266 & \\
\hline 167 & 3 & 1 & smallmouth bass & Centrarchidae & 24.8 & 220 & 137 & 270 & \\
\hline 168 & 3 & 2 & smallmouth bass & Centrarchidae & 26.2 & 228 & 137 & 270 & \\
\hline 169 & 3 & 3 & smallmouth bass & Centrarchidae & 25.1 & 206 & 138 & 446 & \\
\hline 170 & 3 & 4 & smallmouth bass & Centrarchudae & 19.5 & 120 & 138 & 446 & \\
\hline 171 & 3 & 5 & smallmouth bass & Centrarchidae & 18.6 & 102 & 138 & 446 & \\
\hline 172 & 3 & 6 & smallmouth bass & Centrarchudae & 16.8 & 86 & 138 & $446^{\circ}$ & \\
\hline 173 & 3 & 7 & smallmouth bass & Centrarchidae & 15.8 & 60 & 138 & 446 & \\
\hline 174 & 3 & 8 & smallmouth bass & Centrarchidae & 15.6 & 56 & 138 & 446 & \\
\hline 175 & 3 & 9 & smallmouth bass & Centrarchidac & 15.4 & 54 & 138 & 446 & \\
\hline 176 & 3 & 10 & smallmouth bass & Centrarchidac & 15.7 & 50 & 138 & 446 & \\
\hline 177 & 3 & 11 & smallmouth bass & Centrarchidae & 16.7 & 62 & 111 & 458 & \\
\hline 178 & 3 & 12 & smallmouth bass & Centrarchiche & 15.6 & 48 & 111 & 458 & \\
\hline 179 & 3 & 13 & smallmouth bass & Centrarchidbe & 154 & 44 & 111 & 458 & \\
\hline 180 & 3 & 14 & smallmouth bass & Centrarchictac & $1+4$ & 46 & 111 & 458 & \\
\hline 181 & 3 & 15 & smallmouth bass & Centrarchidec & 179 & 88 & 111 & 458 & \\
\hline 182 & 3 & 16 & smallmouth bass & Centrarchicbe & 12 & 24 & 111 & 458 & \\
\hline 183 & 3 & 17 & smallmouth bass & Centrarchudxe & 119 & 22 & 111 & 458 & \\
\hline 184 & 3 & 18 & smallmouth bass & Centrarchudoc & $1+4$ & 36 & 111 & 458 & \\
\hline 185 & 3 & 19 & smallmouth bass & Centrarchude & 125 & 26 & 111 & 458 & \\
\hline 186 & 3 & 20 & smallmouth bass & Centranchidex & 105 & 15.9 & 111 & 458 & \\
\hline 187 & 3 & 21 & smallmouth bass & Centrarchidte & 10 & 14.3 & 111 & 458 & \\
\hline 188 & 3 & 22 & smallmouth bass & Centrarchidne & 112 & 15.1 & 111 & 458 & \\
\hline 189 & 3 & 23 & smallmouth bass & Centrarchidere & 108 & 16 & 111 & 458 & \\
\hline 190 & 3 & 24 & smallmouth bass & Centrarchucte & 85 & 7.5 & 111 & 458 & \\
\hline 191 & 3 & 25 & smallmouth bass & Centrarchidax & $8+$ & 7 & 111 & 458 & \\
\hline 192 & 3 & 26 & smallmouth bass & Centrarchudec & 8 & 5.5 & 111 & 458 & \\
\hline
\end{tabular}




\begin{tabular}{|c|c|c|c|c|c|c|c|c|c|}
\hline \# & $\begin{array}{c}\text { Sub. } \\
\#\end{array}$ & No. & Common Name & Family & $\begin{array}{l}\text { Length } \\
(\mathrm{cm})\end{array}$ & $\begin{array}{c}\text { Weight } \\
(\mathrm{g})\end{array}$ & $\begin{array}{c}\mathrm{Bag} \\
\#\end{array}$ & $\begin{array}{c}\text { Bag Wt } \\
\text { (g) }\end{array}$ & Notes \\
\hline 193 & 3 & 1 & golden redhorse & Catostomidae & 38.1 & 644 & 134 & 662 & \\
\hline 194 & 3 & 2 & golden redhorse & Catostomidae & 34.6 & 488 & 134 & 662 & \\
\hline 195 & 3 & $\overline{3}$ & golden redhorse & Catostomidae & 28.9 & 256 & 135 & 410 & \\
\hline 196 & 3 & 4 & golden redhorse & Catostomidae & 25.6 & 188 & 135 & 410 & \\
\hline 197 & 3 & 5 & golden redhorse & Catostomidae & 27.4 & 230 & 135 & 410 & \\
\hline 198 & 3 & 6 & golden redhorse & Catostomidae & 21.9 & 112 & 136 & 360 & \\
\hline 199 & 3 & 7 & golden redhorse & Catostomidae & 17.4 & 61.1 & 136 & 360 & \\
\hline 200 & 3 & 8 & golden redhorse & Catostomidae & 17.4 & 55.9 & 136 & 360 & \\
\hline 201 & 3 & 9 & golden redhorse & Catostomidae & 16.5 & 47.4 & 136 & 360 & \\
\hline 202 & 3 & 10 & golden redhorse & Catostomidae & 15.3 & 37.7 & 136 & 360 & \\
\hline 203 & 3 & 11 & golden redhorse & Catostomidae & 15.7 & 40.3 & 136 & 360 & \\
\hline 204 & 3 & 12 & golden redhorse & Catostomidae & 15.8 & 43.1 & 136 & 360 & \\
\hline 205 & 3 & 13 & golden redhorse & Catostomidae & 15.7 & 38.8 & 136 & 360 & \\
\hline 206 & 3 & 14 & golden redhorse & Catostomidae & 7.9 & 4.3 & 136 & 360 & \\
\hline 207 & 3 & 15 & golden redhorse & Catostomidae & 6.6 & 2.3 & 136 & 360 & \\
\hline 208 & 3 & 16 & golden redhorse & Catostomidae & 9.5 & 8.9 & 136 & 360 & \\
\hline 209 & 3 & 17 & golden redhorse & Catostomidae & 9 & 7.5 & 136 & 360 & \\
\hline 210 & 3 & 18 & golden redhorse & Catostomidae & 8.4 & 6.3 & 136 & 360 & \\
\hline 211 & 3 & 19 & golden redhorse & Catostomidae & 10.1 & 9.9 & 136 & 360 & \\
\hline 212 & 3 & 20 & golden redhorse & Catostomidae & 9.6 & 10 & 136 & 360 & \\
\hline 213 & 3 & 21 & golden redhorse & Catostomidae & 9.6 & 8.4 & 136 & 360 & \\
\hline 214 & 3 & 22 & golden redhorse & Catostomidae & 10.3 & 10.2 & 136 & 360 & \\
\hline 215 & 3 & 23 & golden redhorse & Catostomidae & 9.6 & 9.1 & 136 & 360 & \\
\hline 216 & 3 & 24 & golden redhorse & Catostomidae & 10.6 & 12.3 & 136 & 360 & \\
\hline 217 & 3 & 25 & golden redhorse & Catostomidae & 14.9 & 29.2 & 136 & 360 & \\
\hline 218 & 3 & 26 & golden redhorse & Catostomidae & 7.3 & $2: 9$ & 136 & 360 & \\
\hline 219 & 3 & 27 & golden redhorse & Catostomidae & 7.1 & 2.4 & 136 & 360 & \\
\hline 220 & 3 & 28 & golden redhorse & Catostomidae & 5.6 & 1.1 & 136 & 360 & \\
\hline 221 & 3 & 29 & golden redhorse & Catostomidae & 13 & 26 & 136 & 360 & \\
\hline 222 & 3 & 1 & northern hog sucker & Catostomidae & 27.1 & 234 & 131 & 308 & \\
\hline 223 & 3 & 2 & northern hog sucker & Catostomidae & 25.6 & 208 & 131 & 308 & \\
\hline 224 & 3 & $\overline{3}$ & northern hog sucker & Catostomidae & 22.8 & 120 & 131 & 308 & \\
\hline 225 & 3 & 4 & northern hog sucker & Catostomidae & 8 & 6.1 & 131 & 308 & \\
\hline 226 & 3 & 1 & highfin carpsucker & Catostomidae & 38.5 & 820 & 132 & 276 & \\
\hline 227 & 3 & $\overline{2}$ & highfin carpsucker & Catostomidae & 34.3 & 590 & 133 & 556 & \\
\hline 228 & 3 & 3 & highfin carpsucker & Catostomidae & 31.4 & 402 & 133 & 556 & \\
\hline 229 & 3 & 1 & carp & Cyprinidae & 57.1 & 2408 & 126 & 890 & \\
\hline 230 & 3 & 2 & carp & Cyprinidae & 56.5 & 2180 & 127 & 684 & \\
\hline 231 & 3 & 3 & carp & Cyprinidae & 45.3 & 1298 & 130 & 580 & \\
\hline 232 & 3 & 4 & carp & Cyprinidae & 45.1 & 1162 & 129 & 452 & \\
\hline 233 & 3 & 1 & mirror carp & Cyprinidae & 50.1 & 1604 & 128 & 574 & \\
\hline 234 & 3 & 1 & shorthead redhorse & Catostomidae & 19.9 & 78.5 & 142 & 768 & \\
\hline 235 & 3 & 2 & shorthead redhorse & Catostomidae & 19.9 & 73.5 & 142 & 768 & \\
\hline 236 & 3 & 1 & gizzard shad & Clupeidae & 14 & 26.7 & 112 & 266 & \\
\hline 237 & 3 & 1 & bluegill & Centrarchidae & 15.7 & 89.1 & 119 & 369 & \\
\hline 238 & 3 & 1 & longear sunfish & Centrarchidae & 11.1 & 32 & 119 & 369 & \\
\hline 239 & 3 & 2 & longear sunfish & Centrarchidae & 10.1 & 18.7 & 119 & 369 & \\
\hline 240 & $\overline{3}$ & 3 & longear sunfish & Centrarchidae & 8 & 9.9 & 119 & 369 & \\
\hline 241 & 3 & 1 & golden shiner & Cyprinidae & 9.3 & 7.7 & 112 & 266 & \\
\hline
\end{tabular}




\begin{tabular}{|c|c|c|c|c|c|c|c|c|c|}
\hline$\#$ & $\begin{array}{c}\text { Sub. } \\
\#\end{array}$ & No. & Common Name & Family & $\begin{array}{l}\text { Length } \\
(\mathrm{cm})\end{array}$ & $\begin{array}{l}\text { Weight } \\
\text { (g) }\end{array}$ & $\begin{array}{c}\text { Bag } \\
\#\end{array}$ & $\begin{array}{c}\text { Bag Wt } \\
\text { (g) }\end{array}$ & Notes \\
\hline 242 & $\overline{3}$ & 2 & golden shiner & Cyprinidae & 9.5 & 8.3 & 112 & 266 & \\
\hline 243 & 3 & 3 & golden shiner & Cyprinidae & 9.4 & 6.5 & 112 & 266 & \\
\hline 244 & 3 & 4 & golden shiner & Cyprinidae & 9.1 & 6.1 & 112 & 266 & \\
\hline 245 & 3 & 5 & golden shiner & Cyprinidae & 6.5 & 2.1 & 112 & 266 & \\
\hline 246 & 3 & 1 & spotfin shiner & Cyprinidae & 10.9 & 11.9 & 112 & 266 & \\
\hline 247 & 3 & 2 & spotfin shiner & Cyprinidae & 8.1 & 4.2 & 112 & 266 & \\
\hline 248 & 3 & 3 & spotfin shiner & Cyprinidae & 7.3 & 3.6 & 112 & 266 & \\
\hline 249 & 4 & 1 & carp & Cyprinidae & 50.3 & 1594 & 139 & 852 & \\
\hline 250 & 4 & 2 & carp & Cyprinidae & 44.8 & 1200 & 140 & 398 & \\
\hline 251 & 4 & 3 & carp & Cyprinidae & 58 & 2456 & 141 & 640 & \\
\hline 252 & 4 & 4 & carp & Cyprinidae & 17.5 & 91.5 & 141 & 640 & \\
\hline 253 & 4 & 5 & carp & Cyprinidae & 15.2 & 54.8 & 141 & 640 & \\
\hline 254 & 4 & 1 & smallmouth bass & Centrarchidae & 25.5 & 220 & 143 & 154 & \\
\hline 255 & 4 & 2 & smallmouth bass & Centrarchidae & 19.5 & 114 & 143 & 154 & \\
\hline 256 & 4 & 3 & smallmouth bass & Centrarchidae & 13.7 & 38.1 & 143 & 154 & \\
\hline 257 & 4 & 4 & smallmouth bass & Centrarchidae & 10.4 & 12.8 & 143 & 154 & \\
\hline 258 & 4 & 1 & golden redhorse & Catostomidae & 39.6 & 740 & 142 & 768 & \\
\hline 259 & 4 & 2 & golden redhorse & Catostomidae & 35.6 & 630 & 142 & 768 & \\
\hline 260 & 4 & 3 & golden redhorse & Catostomidae & 36.5 & 578 & 144 & 618 & \\
\hline 261 & 4 & 4 & golden redhorse & Catostomidae & 36.2 & 576 & 144 & 618 & \\
\hline 262 & 4 & 5 & golden redhorse & Catostomidae & 30 & 320 & 145 & 480 & \\
\hline 263 & 4 & 6 & golden redhorse & Catostomidae & 25.3 & 196 & 145 & 480 & \\
\hline 264 & 4 & 7 & golden redhorse & Catostomidae & 18.5 & 73.3 & 145 & 480 & \\
\hline 265 & 4 & 8 & golden redhorse & Catostomidae & 18 & 60.3 & 145 & 480 & \\
\hline 266 & 4 & 9 & golden redhorse & Catostomidae & 8.4 & 6.2 & 145 & 480 & \\
\hline 267 & 4 & 10 & golden redhorse & Catostomidae & 8.6 & 6.3 & 145 & 480 & \\
\hline 268 & 4 & 1 & shorthead redhorse & Catostomidae & 20.5 & 87.8 & 145 & 480 & \\
\hline 269 & 4 & 1 & gizzard shad & Clupeidae & 27 & 212 & 112 & 266 & \\
\hline 270 & 4 & 2 & gizzard shad & Clupeidae & 13.6 & 28.9 & 112 & 266 & \\
\hline 271 & 4 & 1 & golden shiner & Cyprinidae & 9.2 & 8.5 & 112 & 266 & \\
\hline 272 & 4 & 2 & golden shiner & Cyprinidae & 7.8 & 5.2 & 112 & 266 & \\
\hline 273 & 4 & 3 & golden shiner & Cyprinidae & 7.4 & 4.2 & 112 & 266 & \\
\hline 274 & 4 & 1 & longear sunfish & Centrarchidae & 11.9 & 38.9 & 119 & 369 & \\
\hline 275 & 4 & 2 & longear sunfish & Centrarchidae & 11.5 & 39 & 119 & 369 & ulcer behind ear flap \\
\hline 276 & 4 & 3 & longear sunfish & Centrarchidae & 12 & 43.5 & 119 & 369 & \\
\hline 277 & 4 & 1 & spotfin shiner & Cyprinidae & 9 & 6.8 & 112 & 266 & \\
\hline 278 & 4 & 2 & spotfin shiner & Cyprinidae & 8.6 & 5.5 & 112 & 266 & \\
\hline 279 & 4 & 3 & spotfin shiner & Cyprinidae & 8.1 & 4.7 & 112 & 266 & \\
\hline 280 & 4 & 4 & spotfin shiner & Cyprinidae & 7.5 & 4 & 112 & 266 & \\
\hline 281 & 4 & 5 & spotfin shiner & Cyprinidae & 7.2 & 2.9 & 112 & 266 & \\
\hline 282 & 4 & 6 & spottin shiner & Cyprinidae & 6 & 1.7 & 112 & 266 & \\
\hline
\end{tabular}


Appendix C. Listing of the lengths and weights of fish captured at River Mile 24, 1994.

\begin{tabular}{|c|c|c|c|c|c|c|c|c|c|}
\hline$\#$ & $\begin{array}{c}\text { Sub. } \\
\#\end{array}$ & No. & Common Name & Family & $\begin{array}{l}\text { Length } \\
(\mathrm{cm})\end{array}$ & $\begin{array}{l}\text { Weight } \\
\text { (g) }\end{array}$ & $\begin{array}{c}\text { Bag } \\
\#\end{array}$ & $\begin{array}{c}\text { Bag Wt } \\
\text { (g) }\end{array}$ & Notes \\
\hline 1 & 1 & 1 & gizzard shad & Clupeidae & 27.4 & 209 & 201 & 355 & \\
\hline 2 & 1 & 2 & gizzard shad & Clupeidae & 25.9 & 185 & 201 & 355 & \\
\hline 3 & 1 & 3 & gizzard shad & Clupeidae & 26 & 176 & 201 & 355 & \\
\hline 4 & 1 & 4 & gizzard shad & Clupeidae & 26.6 & 207 & 202 & 299 & \\
\hline 5 & 1 & 5 & gizzard shad & Clupeidae & 25.9 & 148 & 202 & 299 & \\
\hline 6 & 1 & 6 & gizzard shad & Clupeidae & 24.4 & 146 & 202 & 299 & \\
\hline 7 & 1 & 7 & gizzard shad & Clupeidae & 26.9 & 199 & 203 & 386 & \\
\hline 8 & 1 & 8 & gizzard shad & Clupeidae & 20.9 & 92 & 203 & 386 & \\
\hline 9 & 1 & 9 & gizzard shad & Clupeidae & 23.5 & 131 & 203 & 386 & \\
\hline 10 & 1 & 10 & gizzard shad & Clupeidae & 23.6 & 145 & 203 & 386 & \\
\hline 11 & 1 & 11 & gizzard shad & Clupeidae & 22.7 & 119 & 203 & 386 & \\
\hline 12 & 1 & 1 & freshwater drum & Sciaenidae & 36.7 & 822 & 204 & 464 & \\
\hline 13 & 1 & 2 & freshwater drum & Sciaenidae & 35.9 & 620 & 205 & 317 & \\
\hline 14 & 1 & 3 & freshwater drum & Sciaenidae & 27.8 & 275 & 206 & 272 & \\
\hline 15 & 1 & 4 & freshwater drum & Sciaenidae & 27.6 & 258 & 206 & 272 & \\
\hline 16 & 1 & 5 & freshwater drum & Sciaenidae & 28.4 & 311 & 207 & 295 & \\
\hline 17 & 1 & 6 & freshwater drum & Sciaenidae & 26 & 218 & 207 & 295 & \\
\hline 18 & 1 & 7 & freshwater drum & Sciaenidae & 24.6 & 182 & 208 & 339 & \\
\hline 19 & 1 & 8 & freshwater drum & Sciaenidae & 26.5 & 223 & 208 & 339 & \\
\hline 20 & 1 & 9 & freshwater drum & Sciaenidae & 14.2 & 36.6 & 208 & 339 & \\
\hline 21 & 1 & 10 & freshwater drum & Sciaenidae & $1+.9$ & 41.3 & 208 & 339 & \\
\hline 22 & 1 & 11 & freshwater drum & Sciaenidae & $1+.4$ & 34.3 & 208 & 339 & \\
\hline 23 & 1 & 12 & freshwater drum & Sciaenidae & 13.5 & 29.2 & 208 & 339 & \\
\hline 24 & 1 & 1 & black buffalo & Catostomidae & 53.2 & 2744 & 209 & 756 & \\
\hline 25 & 1 & 2 & black buffalo & Catostomidae & 4 & 1398 & 210 & 390 & \\
\hline 26 & 1 & 3 & black buffalo & Catostomidae & 39.4 & 989 & 211 & 328 & \\
\hline 27 & 1 & 1 & quillback & Catostomidae & 40.4 & 912 & 212 & 279 & \\
\hline 28 & 1 & 1 & golden redhorse & Catostomidac & 42.6 & 1001 & 213 & 356 & \\
\hline 29 & 1 & 2 & golden redhorse & Catostomidae & 35.4 & 531 & 214 & 397 & \\
\hline 30 & 1 & 3 & golden redhorse & Catostomidae & $3+.3$ & 504 & 214 & 397 & \\
\hline 31 & 1 & 4 & golden redhorse & Catostomidac & 33 & 452 & 215 & 268 & \\
\hline 32 & 1 & 5 & golden redhorse & Catostomadac & 29.7 & 303 & 215 & 268 & \\
\hline 33 & 1 & 6 & golden redhorse & Catostomidae & 79 & 5.5 & $\mathbf{k}$ & $\underline{k}$ & uc collection \\
\hline 34 & 1 & 1 & northern hog sucker & Catostomidae & 354 & 585 & 216 & 212 & \\
\hline 35 & 1 & 2 & northern hog sucker & Catostomidac & 87 & 7.2 & 216 & 212 & \\
\hline 36 & 1 & 1 & logperch & Percidae & 131 & 23.2 & $\mathbf{k}$ & $\mathbf{k}$ & uc collection \\
\hline 37 & 1 & 1 & smallmouth bass & Centrarchicte & 134 & 31.3 & 217 & 264 & \\
\hline 38 & 1 & 2 & smallmouth bass & Centrarchiche & 117 & 22 & 217 & 264 & \\
\hline 39 & 1 & 3 & smallmouth bass & Centrarchicke & $1+9$ & 43.5 & 217 & 264 & \\
\hline 40 & 1 & 4 & smallmouth bass & Centrarchidex & $1+t$ & 39 & 217 & 264 & \\
\hline 41 & 1 & 5 & smallmouth bass & Centrarchicte & 134 & 32.3 & 217 & 264 & \\
\hline 42 & 1 & 6 & smallmouth bass & Centrarchudac & 118 & 21.2 & 217 & 264 & \\
\hline 43 & 1 & 7 & smallmouth bass & Centrarchuche & $2+5$ & 277 & $\mathbf{k}$ & $\mathbf{k}$ & returned \\
\hline 44 & 1 & 1 & longear sunfish & Centrarchucte & 124 & 52.5 & 219 & 234 & \\
\hline 45 & 1 & 2 & longear sunfish & Centrarchudxe & 102 & 24.7 & 219 & 234 & \\
\hline
\end{tabular}




\begin{tabular}{|c|c|c|c|c|c|c|c|c|c|}
\hline$\#$ & $\begin{array}{c}\text { Sub. } \\
\#\end{array}$ & No. & Common Name & Family & $\begin{array}{l}\text { Length } \\
\text { (cm) }\end{array}$ & $\begin{array}{l}\text { Weight } \\
\text { (g) }\end{array}$ & $\begin{array}{c}\text { Bag } \\
\#\end{array}$ & $\begin{array}{c}\text { Bag Wt } \\
\text { (g) }\end{array}$ & Notes \\
\hline 46 & 1 & 3 & longear sunfish & Tentrarchidae & 9.8 & 21.4 & 219 & 234 & \\
\hline 47 & 1 & 4 & longear sunfish & Centrarchidae & 6.6 & 7 & 219 & 234 & \\
\hline 48 & 1 & 5 & longear sunfish & Centrarchidae & 6.3 & 6.5 & 219 & 234 & \\
\hline 49 & 1 & 6 & longear sunfish & Centrarchidae & 6.4 & 5.4 & 219 & 234 & \\
\hline 50 & 1 & 7 & longear sunfish & Centrarchidae & 8.3 & 4.8 & 218 & 48 & \\
\hline 51 & 1 & 8 & longear sunfish & Centrarchidae & 7.2 & 3.2 & 218 & 48 & \\
\hline 52 & 1 & 9 & longear sunfish & Centrarchidae & 7.1 & 3.3 & 218 & 48 & \\
\hline 53 & 1 & 10 & longear sunfish & Centrarchidae & 6.8 & 2.2 & 218 & 48 & \\
\hline 54 & 1 & 11 & longear sunfish & Centrarchidae & 7 & 2.3 & 218 & 48 & \\
\hline 55 & 1 & 12 & longear sunfish & Centrarchidae & 7.6 & 3.1 & 218 & 48 & \\
\hline 56 & 1 & 13 & longear sunfish & Centrarchidae & 6.9 & 3.5 & 218 & 48 & \\
\hline 57 & 1 & 14 & longear sunfish & Centrarchidae & 6.5 & 2.7 & 218 & 48 & \\
\hline 58 & 1 & 15 & longear sunfish & Centrarchidae & 6.8 & 2.9 & 218 & 48 & \\
\hline 59 & 1 & 16 & longear sunfish & Centrarchidae & 6.1 & 2.6 & 218 & 48 & \\
\hline 60 & 1 & 17 & longear sunfish & Centrarchidae & 6.4 & 2.5 & 218 & 48 & \\
\hline 61 & 1 & 18 & longear sunfish & Centrarchidae & 4.6 & 1 & 218 & 48 & \\
\hline 62 & 1 & 1 & bluntnose minnow & Cyprinidae & 7.1 & 3.3 & 218 & 48 & \\
\hline 63 & 1 & 1 & spotfin shiner & Cyprinidae & 7.9 & 5.4 & 218 & 48 & \\
\hline 64 & 1 & 1 & carp & Cyprinidae & 56.2 & 2250 & 220 & 428 & \\
\hline 65 & 1 & 2 & carp & Cyprinidae & 46.7 & 1620 & 221 & 438 & \\
\hline 66 & 1 & 3 & carp & Cyprinidae & 51.1 & 1749 & 222 & 424 & \\
\hline 67 & 1 & 1 & striped bass & Percichthyidae & 33.3 & 334 & $\mathbf{k}$ & $\mathbf{k}$ & returned \\
\hline 68 & 1 & 2 & striped bass & Percichthyidae & 23.3 & 126 & $\underline{\mathbf{k}}$ & $\mathbf{k}$ & returned \\
\hline 69 & 1 & 3 & striped bass & Percichthyidae & 23.8 & 164 & $\mathbf{k}$ & $\mathbf{k}$ & returned \\
\hline 70 & 1 & 4 & striped bass & Percichthyidae & 27.2 & 190 & $\mathbf{k}$ & $\mathbf{k}$ & returned \\
\hline 71 & 1 & 5 & striped bass & Percichthyidae & 18.7 & 70 & $\mathbf{k}$ & $\mathbf{k}$ & returned \\
\hline 72 & 2 & 1 & freshwater drum & Sciaenidae & 42.5 & 1006 & 223 & 572 & \\
\hline 73 & 2 & 2 & freshwater drum & Sciaenidae & 39.6 & 842 & 223 & 572 & \\
\hline 74 & 2 & 3 & freshwater drum & Sciaenidae & 31.2 & 460 & 224 & 368 & \\
\hline 75 & 2 & 4 & freshwater drum & Sciaenidae & 40.7 & 923 & 224 & 368 & \\
\hline 76 & 2 & 5 & freshwater drum & Sciaenidae & 32.8 & 424 & 225 & 240 & \\
\hline 77 & 2 & 6 & freshwater drum & Sciaenidae & 28.3 & 300 & 225 & 240 & \\
\hline 78 & 2 & 7 & freshwater drum & Sciaenidae & 27 & 335 & 226 & 240 & \\
\hline 79 & 2 & 8 & freshwater drum & Sciaenidae & 28 & 305 & 226 & 240 & \\
\hline 80 & 2 & 9 & freshwater drum & Sciaenidae & 26.8 & 250 & 226 & 240 & \\
\hline 81 & 2 & 10 & freshwater drum & Sciaenidae & 27.2 & 255 & 227 & 288 & \\
\hline 82 & 2 & 11 & freshwater drum & Sciaenidae & 29.8 & 278 & 227 & 288 & \\
\hline 83 & 2 & 12 & freshwater drum & Sciaenidae & 28.6 & 330 & 227 & 288 & \\
\hline 84 & 2 & 13 & freshwater drum & Sciaenidae & 28 & 259 & 228 & 202 & \\
\hline 85 & 2 & 14 & freshwater drum & Sciaenidae & 23.8 & 169 & 228 & 202 & \\
\hline 86 & 2 & 15 & freshwater drum & Sciaenidae & 22.2 & 128 & 228 & 202 & \\
\hline 87 & 2 & 16 & freshwater drum & Sciaenidae & 16.2 & 45.6 & 228 & 202 & \\
\hline 88 & 2 & 1 & smallmouth buffalo & Catostomidae & 65.7 & 4648 & 234 & 1196 & \\
\hline 89 & 2 & 1 & carp & Cyprinidae & 45.9 & 1830 & 229 & 420 & \\
\hline 90 & 2 & 2 & carp & Cyprinidae & 49.8 & 1730 & 230 & 508 & \\
\hline 91 & 2 & 3 & carp & Cyprinidae & 43.3 & 1443 & 231 & 342 & \\
\hline 92 & 2 & 1 & golden redhorse & Catostomidae & 39.9 & 761 & 232 & 246 & \\
\hline 93 & 2 & 2 & golden redhorse & Catostomidae & 36.4 & 521 & 233 & 311 & \\
\hline 94 & 2 & 3 & golden redhorse & Catostomidae & 33.6 & 410 & 233 & 311 & \\
\hline
\end{tabular}




\begin{tabular}{|c|c|c|c|c|c|c|c|c|c|}
\hline$\#$ & $\begin{array}{c}\text { Sub. } \\
\#\end{array}$ & No. & Common Name & Family & $\begin{array}{l}\text { Length } \\
(\mathrm{cm})\end{array}$ & $\begin{array}{l}\text { Weight } \\
\text { (g) }\end{array}$ & $\begin{array}{c}\text { Bag } \\
\#\end{array}$ & $\begin{array}{c}\text { Bag Wt } \\
\text { (g) }\end{array}$ & Notes \\
\hline 95 & 2 & 1 & Igizzard shad & Clupeidae & 26.2 & 174 & 235 & 253 & \\
\hline 96 & 2 & 2 & gizzard shad & Clupeidae & 24.7 & 144 & 235 & 253 & \\
\hline 97 & 2 & 3 & gizzard shad & Clupeidae & 22.2 & 107 & 235 & 253 & \\
\hline 98 & 2 & 1 & channel catfish & Ictaluridae & 39.4 & 562 & 236 & 265 & \\
\hline 99 & 2 & 2 & channel catfish & Ictaluridae & 9.6 & 8.3 & 236 & 265 & \\
\hline 100 & 2 & 1 & flathead catfish & Ictaluridae & 35.9 & 429 & 236 & 265 & \\
\hline 101 & 2 & 1 & river carpsucker & Catostomidae & 44.4 & 1570 & 237 & 522 & \\
\hline 102 & 2 & 1 & black buffalo & Catostomidae & 49.9 & 1411 & 238 & 434 & \\
\hline 103 & 2 & 1 & longear sunfish & Centrarchidae & 15.6 & 109 & 219 & 434 & \\
\hline 104 & 2 & 2 & longear sunfish & Centrarchidae & 10.8 & 28.3 & 219 & 434 & \\
\hline 105 & 2 & 3 & longear sunfish & Centrarchidae & 5.6 & 3.1 & 219 & 434 & \\
\hline 106 & 2 & 1 & striped bass & Percichthyidae & 15.5 & 44.1 & 217 & 434 & \\
\hline 107 & 2 & 2 & striped bass & Percichthyidae & 24 & 194 & $\mathbf{k}$ & $\mathbf{k}$ & returned \\
\hline 108 & 2 & 1 & smallmouth bass & Centrarchidae & 13.7 & 35.8 & 217 & 434 & \\
\hline 109 & 2 & 2 & smallmouth bass & Centrarchidae & 11 & 18.1 & 217 & 434 & \\
\hline 110 & 2 & 1 & spotfin shiner & Cyprinidae & 7.7 & 4.1 & 218 & 434 & \\
\hline 111 & 3 & 1 & freshwater drum & Sciaenidae & 32 & 469 & 239 & 480 & \\
\hline 112 & 3 & 2 & freshwater drum & Sciaenidae & 27.4 & 271 & 239 & 480 & \\
\hline 113 & 3 & 3 & freshwater drum & Sciaenidae & 28.3 & 290 & 239 & 480 & \\
\hline 114 & 3 & 4 & freshwater drum & Sciaenidae & 25.2 & 168 & 239 & 480 & \\
\hline 115 & 3 & 1 & channel catfish & Ictaluridae & 43.5 & 830 & 243 & 556 & \\
\hline 116 & 3 & 2 & channel catfish & Ictaluridae & 41.1 & 670 & 243 & 556 & \\
\hline 117 & 3 & 1 & flathead catfish & Ictaluridae & 47.4 & 1058 & 243 & 556 & \\
\hline 118 & 3 & 1 & smallmouth bass & Centrarchidae & 14.8 & 47.1 & 217 & 556 & \\
\hline 119 & 3 & 2 & smallmouth bass & Centrarchidae & 32.7 & 426 & $\mathbf{k}$ & $\mathbf{k}$ & returned \\
\hline 120 & 3 & 1 & smallmouth buffalo & Catostomidae & 58.5 & 3338 & 240 & 690 & \\
\hline 121 & 3 & 1 & carp & Cyprinidae & 59.1 & 3016 & 241 & 510 & \\
\hline 122 & 3 & 1 & black buffalo & Catostomidae & 48.5 & 1367 & 242 & 225 & \\
\hline 123 & 3 & 1 & striped bass & Percichthyidae & 32 & 516 & $\mathbf{k}$ & $\mathbf{k}$ & returned \\
\hline 124 & 3 & 2 & striped bass & Percichthyidae & 27.8 & 256 & $\mathbf{k}$ & $\mathbf{k}$ & returned \\
\hline 125 & 4 & 1 & gizzard shad & Clupeidae & 28.7 & 242 & 244 & 468 & \\
\hline 126 & 4 & 2 & gizzard shad & Clupeidae & 27.5 & 240 & 244 & 468 & \\
\hline 127 & 4 & 3 & gizzard shad & Clupeidae & 28.6 & 244 & 244 & 468 & \\
\hline 128 & 4 & 4 & gizzard shad & Clupeidae & 26.2 & 269 & 244 & 468 & \\
\hline 129 & 4 & 5 & gizzard shad & Clupeidae & 26.4 & 200 & 244 & 468 & \\
\hline 130 & 4 & 6 & gizzard shad & Clupeidae & 25.4 & 149 & 245 & 300 & \\
\hline 131 & 4 & 7 & gizzard shad & Clupeidae & 21.8 & 109 & 245 & 300 & \\
\hline 132 & 4 & 8 & gizzard shad & Clupeidae & 22.2 & 100 & 245 & 300 & \\
\hline 133 & 4 & 9 & gizzard shad & Clupeidae & 22.8 & 104 & 245 & 300 & \\
\hline 134 & 4 & 10 & gizzard shad & Clupeidae & 20.7 & 75 & 245 & 300 & \\
\hline 135 & 4 & 11 & gizzard shad & Clupeidae & 20.5 & 89 & 246 & 340 & \\
\hline 136 & 4 & 12 & gizzard shad & Clupeidae & 19.4 & 69 & 246 & 340 & \\
\hline 137 & 4 & 13 & gizzard shad & Clupeidae & 26.6 & 205 & 246 & 340 & \\
\hline 138 & 4 & 14 & gizzard shad & Clupeidae & 24.7 & 155 & 246 & 340 & \\
\hline 139 & 4 & 15 & gizzard shad & Clupeidae & 26.5 & 192 & 246 & 340 & \\
\hline 140 & 4 & 16 & gizzard shad & Clupeidae & 23.3 & 111 & 246 & 340 & \\
\hline 141 & 4 & 17 & gizzard shad & Clupeidae & 26.2 & 170 & 246 & 340 & \\
\hline 142 & 4 & 18 & gizzard shad & Clupeidae & 23 & 118 & 247 & 486 & \\
\hline 143 & 4 & 19 & gizzard shad & Clupeidae & 24 & 120 & 247 & 486 & \\
\hline
\end{tabular}




\begin{tabular}{|c|c|c|c|c|c|c|c|c|c|}
\hline$\overline{\#}$ & $\begin{array}{c}\text { Sub. } \\
\#\end{array}$ & No. & Common Name & Family & $\begin{array}{l}\text { Length } \\
(\mathrm{cm})\end{array}$ & $\begin{array}{c}\text { Weight } \\
\text { (g) }\end{array}$ & $\begin{array}{c}\text { Bag } \\
\#\end{array}$ & $\begin{array}{c}\text { Bag Wt } \\
\text { (g) }\end{array}$ & Notes \\
\hline$\overline{144}$ & 4 & 20 & gizzard shad & Clupeidae & 21.6 & 105 & 247 & 486 & \\
\hline 145 & 4 & 21 & gizzard shad & Clupeidae & 21.4 & 98 & 247 & 486 & \\
\hline 146 & 4 & 22 & gizzard shad & Clupeidae & 20.6 & 79 & 247 & 486 & \\
\hline 147 & 4 & 23 & gizzard shad & Clupeidae & 15.2 & 28.4 & 248 & 286 & \\
\hline 148 & 4 & 24 & gizzard shad & Clupeidae & 13 & 20.4 & 248 & 286 & \\
\hline 149 & 4 & 25 & gizzard shad & Clupeidae & 12.5 & 20.4 & 248 & 286 & \\
\hline 150 & 4 & 26 & gizzard shad & Clupeidae & 11.4 & 14.4 & 248 & 286 & \\
\hline 151 & 4 & 27 & gizzard shad & Clupeidae & 12.5 & 17.6 & 248 & 286 & \\
\hline 152 & 4 & 1 & freshwater drum & Sciaenidae & 39.4 & 795 & 249 & 348 & \\
\hline 153 & 4 & 2 & freshwater drum & Sciaenidae & 34.1 & 500 & 249 & 348 & \\
\hline 154 & 4 & 3 & freshwater drum & Sciaenidae & 29.5 & 410 & 250 & 280 & \\
\hline 155 & 4 & 4 & freshwater drum & Sciaenidae & 28.9 & 318 & 250 & 280 & \\
\hline 156 & 4 & 5 & freshwater drum & Sciaenidae & 30 & 341 & 250 & 280 & \\
\hline 157 & 4 & 6 & freshwater drum & Sciaenidae & 27.6 & 295 & 251 & 302 & \\
\hline 158 & 4 & 7 & freshwater drum & Sciaenidae & 30.4 & 410 & 251. & 302 & \\
\hline 159 & 4 & 8 & freshwater drum & Sciaenidae & 28.6 & 300 & 251 & 302 & \\
\hline 160 & 4 & 9 & freshwater drum & Sciaenidae & 30.4 & 358 & 252 & 248 & \\
\hline 161 & 4 & 10 & freshwater drum & Sciaenidae & 24.9 & 200 & 252 & 248 & \\
\hline 162 & 4 & 11 & freshwater drum & Sciaenidae & 25.4 & 200 & 252 & 248 & \\
\hline 163 & 4 & 12 & freshwater drum & Sciaenidae & 23.7 & 180 & 253 & 232 & \\
\hline 164 & 4 & 13 & freshwater drum & Sciaenidae & 22.1 & 140 & 253 & 232 & \\
\hline 165 & 4 & 14 & freshwater drum & Sciaenidae & 23.7 & 149 & 253 & 232 & \\
\hline 166 & 4 & 15 & freshwater drum & Sciaenidae & 21.5 & 124 & 253 & 232 & \\
\hline 167 & 4 & 16 & freshwater drum & Sciaenidae & 15.4 & 42.3 & 253 & 232 & \\
\hline 168 & 4 & 17 & freshwater drum & Sciaenidae & 13.2 & 25.5 & 253 & 232 & \\
\hline 169 & 4 & 1 & golden redhorse & Catostomidae & 33.4 & 460 & 254 & 416 & \\
\hline 170 & 4 & 2 & golden redhorse & Catostomidae & 33.7 & 475 & 254 & 416 & \\
\hline 171 & 4 & 3 & golden redhorse & Catostomidae & 32.6 & 440 & 254 & 416 & \\
\hline 172 & 4 & 4 & golden redhorse & Catostomidae & 33 & 429 & 255 & 346 & \\
\hline 173 & 4 & 5 & golden redhorse & Catostomidae & 32.8 & 390 & 255 & 346 & \\
\hline 174 & 4 & 6 & golden redhorse & Catostomidae & 26.8 & 223 & 255 & 346 & \\
\hline 175 & 4 & 7 & golden redhorse & Catostomidae & 18.7 & 79 & 256 & 258 & \\
\hline 176 & 4 & 8 & golden redhorse & Catostomidae & 11.2 & 14.9 & 256 & 258 & \\
\hline 177 & 4 & 1 & shorthead redhorse & Catostomidae & 37.4 & 512 & 256 & 258 & \\
\hline 178 & 4 & 1 & flathead catfish & Ictaluridae & 50.9 & 1330 & 257 & 360 & \\
\hline 179 & 4 & 1 & channel catfish & Ictaluridae & 36.7 & 402 & 257 & 360 & \\
\hline 180 & 4 & 2 & channel catfish & Ictaluridae & 11.1 & 11 & 257 & 360 & \\
\hline 181 & 4 & 3 & channel catfish & Ictaluridae & 10.4 & 10.1 & 257 & 360 & \\
\hline 182 & 4 & 1 & smallmouth bass & Centrarchidae & 14.2 & 40.1 & 217 & 264 & \\
\hline 183 & 4 & 2 & smallmouth bass & Centrarchidae & 13.2 & 32.5 & 217 & 264 & \\
\hline 184 & 4 & 3 & smallmouth bass & Centrarchidae & 26.1 & 256 & $\mathbf{k}$ & $\mathbf{k}$ & returned \\
\hline 185 & 4 & 1 & longear sunfish & Centrarchidae & 11 & 34 & 219 & 234 & \\
\hline 186 & 4 & 2 & longear sunfish & Centrarchidae & 8.9 & 15.9 & 219 & 234 & \\
\hline 187 & 4 & 3 & longear sunfish & Centrarchidae & 6.8 & 6.6 & 219 & 234 & \\
\hline 188 & 4 & 1 & bluegill & Centrarchidae & 11.5 & 34.8 & 219 & 234 & \\
\hline 189 & 4 & 1 & spotfin shiner & Cyprinidae & 6.9 & 2.2 & 218 & 48 & \\
\hline 190 & 4 & 2 & spotfin shiner & Cyprinidae & 7.4 & 2.7 & 218 & 48 & \\
\hline 191 & 4 & 3 & spotfin shiner & Cyprinidae & 7.5 & 2 & 218 & 48 & \\
\hline 192 & 4 & 4 & spotfin shiner & Cyprinidae & 7.5 & 2.6 & 218 & 48 & \\
\hline
\end{tabular}




\begin{tabular}{|c|c|c|l|l|c|c|c|c|l|}
\hline$\#$ & $\begin{array}{c}\text { Sub. } \\
\#\end{array}$ & No. & Common Name & Family & $\begin{array}{c}\text { Length } \\
(\mathrm{cm})\end{array}$ & $\begin{array}{c}\text { Weight } \\
(\mathrm{g})\end{array}$ & $\begin{array}{c}\text { Bag } \\
\#\end{array}$ & $\begin{array}{c}\text { Bag Wt } \\
(\mathrm{g})\end{array}$ & Notes \\
\hline \hline 193 & 4 & 5 & spotfin shiner & Cyprinidae & 6.8 & 1.9 & 218 & 48 & \\
\hline 194 & 4 & 1 & carp & Cyprinidae & 62.1 & 3705 & 258 & 686 & \\
\hline 195 & 4 & 2 & carp & Cyprinidae & 53.4 & 2468 & 259 & 732 & \\
\hline 196 & 4 & 1 & striped bass & Percichthyidae & 22.8 & 128 & $\mathrm{k}$ & $\mathrm{k}$ & returned \\
\hline 197 & 4 & 2 & striped bass & Percichthyidae & 30.4 & 320 & $\mathrm{k}$ & $\mathrm{k}$ & returned \\
\hline 198 & 4 & 3 & striped bass & Percichthyidae & 24.2 & 164 & $\mathrm{k}$ & $\mathrm{k}$ & returned \\
\hline 199 & 4 & 1 & sauger & Percidae & 29.2 & 188 & $\mathrm{k}$ & $\mathrm{k}$ & returned \\
\hline 200 & 4 & 2 & sauger & Percidae & 31.1 & 228 & $\mathrm{k}$ & $\mathrm{k}$ & returned \\
\hline
\end{tabular}


Appendix D. Listing of the lengths and weights of fish captured at River Mile 19, 1994.

\begin{tabular}{|c|c|c|c|c|c|c|c|c|c|}
\hline$\overline{\#}$ & $\begin{array}{c}\text { Sub. } \\
\#\end{array}$ & No. & Common Name & Family & $\begin{array}{l}\text { Length } \\
(\mathrm{cm})\end{array}$ & $\begin{array}{c}\text { Weight } \\
\text { (g) }\end{array}$ & $\begin{array}{c}\text { Bag } \\
\#\end{array}$ & $\begin{array}{c}\text { Bag Wt } \\
\text { (g) }\end{array}$ & Notes \\
\hline 1 & 1 & 1 & gizzard shad & Clupeidae & 10.4 & 11.9 & 301 & 230 & \\
\hline 2 & 1 & 2 & gizzard shad & Clupeidae & 12.4 & 17.5 & 301 & 230 & \\
\hline 3 & 1 & 3 & gizzard shad & Clupeidae & 12.6 & 20.7 & 301 & 230 & \\
\hline 4 & 1 & 4 & gizzard shad & Clupeidae & 12.7 & 21 & 301 & 230 & \\
\hline 5 & 1 & 5 & gizzard shad & Clupeidae & 10.9 & 11.8 & 301 & 230 & \\
\hline 6 & 1 & 6 & gizzard shad & Clupeidae & 10.5 & 12 & 302 & 187 & \\
\hline 7 & 1 & 7 & gizzard shad & Clupeidae & 10.3 & 11.1 & 302 & 187 & \\
\hline 8 & 1 & 8 & gizzard shad & Clupeidae & 11.1 & 14.7 & 302 & 187 & \\
\hline 9 & 1 & 9 & gizzard shad & Clupeidae & 12.1 & 18.6 & 302 & 187 & \\
\hline 10 & 1 & 10 & gizzard shad & Clupeidae & 11.4 & 13.2 & 302 & 187 & \\
\hline 11 & 1 & 11 & gizzard shad & Clupeidae & 11.6 & 15.4 & 302 & 187 & \\
\hline 12 & 1 & 12 & gizzard shad & Clupeidae & 10.8 & 12 & 303 & 316 & \\
\hline 13 & 1 & 13 & gizzard shad & Clupeidae & 12.5 & 19.4 & 303 & 316 & \\
\hline 14 & 1 & 14 & gizzard shad & Clupeidae & 14.3 & 24.8 & 303 & 316 & \\
\hline 15 & 1 & 15 & gizzard shad & Clupeidae & 10.1 & 12 & 303 & 316 & \\
\hline 16 & 1 & 16 & gizzard shad & Clupeidae & 11.4 & 13.8 & 303 & 316 & \\
\hline 17 & 1 & 17 & gizzard shad & Clupeidae & 12.0 & 14.9 & 303 & 316 & \\
\hline 18 & 1 & 18 & gizzard shad & Clupeidae & 15.1 & 35.7 & 303 & 316 & \\
\hline 19 & 1 & 19 & gizzard shad & Clupeidae & 11.2 & 13.9 & 303 & 316 & \\
\hline 20 & 1 & 20 & gizzard shad & Clupeidae & 8.2 & 7.8 & 303 & 316 & \\
\hline 21 & 1 & 21 & gizzard shad & Chupeidae & 8.4 & 8.4 & 303 & 316 & \\
\hline 22 & 1 & 22 & gizzard shad & Clupeidae & 13.0 & 22.1 & 305 & 287 & \\
\hline 23 & 1 & 23 & gizzard shad & Clupeidae & 13.5 & 22.8 & 305 & 287 & \\
\hline 24 & 1 & 24 & gizzard shad & Clupeidae & 17.6 & 60.5 & 305 & 287 & \\
\hline 25 & 1 & 25 & gizzard shad & Clupeidae & 13.9 & 24.8 & 305 & 287 & \\
\hline 26 & 1 & 26 & gizzard shad & Clupeidae & 13.7 & 26.8 & 305 & 287 & \\
\hline 27 & 1 & 27 & gizzard shad & Clupeidae & 15.6 & 39 & 306 & 309 & \\
\hline 28 & 1 & 28 & gizzard shad & Clupeidae & 12.7 & 21.4 & 306 & 309 & \\
\hline 29 & 1 & 29 & gizzard shad & Clupeidae & 8.6 & 6.9 & 306 & 309 & \\
\hline 30 & 1 & 30 & gizzard shad & Clupeidae & 16.1 & 53.6 & 306 & 309 & \\
\hline 31 & 1 & 31 & gizzard shad & Clupeidae & 11.3 & 15.6 & 306 & 309 & \\
\hline 32 & 1 & 32 & gizzard shad & Clupeidae & 13.9 & 27.5 & 307 & 228 & \\
\hline 33 & 1 & 33 & gizzard shad & Clupeidae & 10.0 & 11.3 & 307 & 228 & \\
\hline 34 & 1 & 34 & gizzard shad & Clupeidae & 11.2 & 15.9 & 307 & 228 & \\
\hline 35 & 1 & 35 & gizzard shad & Clupeidae & 11.4 & 14.2 & 307 & 228 & \\
\hline 36 & 1 & 36 & gizzard shad & Clupeidae & 13.3 & 21.8 & 307 & 228 & \\
\hline 37 & 1 & 37 & gizzard shad & Clupeidae & 9.6 & 9.4 & 307 & 228 & \\
\hline 38 & 1 & 38 & gizzard shad & Clupeidae & 8.7 & 7.8 & 308 & 265 & \\
\hline 39 & 1 & 39 & gizzard shad & Clupeidae & 11.1 & 14.6 & 308 & 265 & \\
\hline 40 & 1 & 40 & gizzard shad & Clupeidae & 17.3 & 52.3 & 308 & 265 & \\
\hline 41 & 1 & 41 & gizzard shad & Clupeidae & 10.4 & 11.4 & 308 & 265 & \\
\hline 42 & 1 & 42 & gizzard shad & Clupeidae & 13.1 & 25.7 & 308 & 265 & \\
\hline 43 & 1 & 43 & gizzard shad & Clupeidae & 11.4 & 14 & 308 & 265 & \\
\hline 44 & 1 & 44 & gizzard shad & Clupeidae & 11.7 & 12.9 & 308 & 265 & \\
\hline 45 & 1 & 45 & gizzard shad & Clupeidae & 13.3 & 21.9 & 309 & 252 & \\
\hline
\end{tabular}




\begin{tabular}{|c|c|c|c|c|c|c|c|c|c|}
\hline$\#$ & $\begin{array}{c}\text { Sub. } \\
\#\end{array}$ & No. & Common Name & Family & $\begin{array}{c}\text { Length } \\
(\mathrm{cm})\end{array}$ & $\begin{array}{c}\text { Weight } \\
\text { (g) }\end{array}$ & $\begin{array}{c}\text { Bag } \\
\#\end{array}$ & $\begin{array}{c}\text { Bag Wt } \\
\text { (g) }\end{array}$ & Notes \\
\hline$\overline{46}$ & $\overline{\overline{1}}$ & $\overline{46}$ & gizzard shad & Clupeidae & 14.8 & 29 & 309 & 252 & \\
\hline 47 & $I$ & 47 & gizzard shad & Clupeidae & 11.6 & 12.8 & 309 & 252 & \\
\hline 48 & 1 & 48 & gizzard shad & Clupeidae & 10.5 & 12.1 & 309 & 252 & \\
\hline 49 & 1 & 49 & gizzard shad & Clupeidae & 14.0 & 25.4 & 309 & 252 & \\
\hline 50 & 1 & 50 & gizzard shad & Clupeidae & 11.3 & 14.2 & 310 & 236 & \\
\hline 51 & 1 & 51 & gizzard shad & Clupeidae & 12.0 & 13.3 & 310 & 236 & \\
\hline 52 & 1 & 52 & gizzard shad & Clupeidae & 10.9 & 12.1 & 310 & 236 & \\
\hline 53 & 1 & 53 & gizzard shad & Clupeidae & 14.8 & 27.9 & 310 & 236 & \\
\hline 54 & 1 & 54 & gizzard shad & Clupeidae & 9.9 & 9.6 & 310 & 236 & \\
\hline 55 & 1 & 1 & carp & Cyprinidae & 42.3 & 941 & 312 & 434 & \\
\hline 56 & 1 & 2 & carp & Cyprinidae & 33.5 & 461 & 313 & 708 & \\
\hline 57 & 1 & 3 & carp & Cyprinidae & 37.8 & 492 & 313 & 708 & \\
\hline 58 & 1 & 1 & river carpsucker & Catostomidae & 38.4 & 768 & 314 & 381 & \\
\hline 93 & 1 & 1 & river carpsucker & Catostomidae & 45.3 & 1251 & 323 & 790 & \\
\hline 94 & 1 & 2 & river carpsucker & Catostomidae & 37.1 & 683 & 324 & 330 & \\
\hline 59 & 1 & 1 & bluegill & Centrarchidae & 11.1 & 31.6 & 315 & 270 & \\
\hline 60 & 1 & 2 & bluegill & Centrarchidae & 4.8 & 3.3 & 315 & 270 & \\
\hline 61 & 1 & 3 & bluegill & Centrarchidae & 4.2 & 3.2 & 315 & 270 & \\
\hline 62 & 1 & 4 & bluegill & Centrarchidae & 9.1 & 16.3 & 315 & 270 & \\
\hline 63 & 1 & 5 & bluegill & Centrarchidae & 11.7 & 33.1 & 315 & 270 & \\
\hline 64 & 1 & 6 & bluegill & Centrarchidae & 10.0 & 20.6 & 315 & 270 & \\
\hline 65 & 1 & 7 & bluegill & Centrarchidae & 4.4 & 2 & 315 & 270 & \\
\hline 66 & 1 & 1 & longear sunfish & Centrarchidae & 6.0 & 4 & 316 & 214 & \\
\hline 67 & 1 & 2 & longear sunfish & Centrarchidae & 4.7 & 1.9 & 316 & 214 & \\
\hline 68 & 1 & 3 & longear sunfish & Centrarchidae & 5.9 & 3.9 & 316 & 214 & \\
\hline 69 & I & 4 & longear sunfish & Centrarchidae & 6.5 & 4.9 & 316 & 214 & \\
\hline 70 & 1 & 5 & longear sunfish & Centrarchidae & 4.8 & 2.1 & 316 & 214 & \\
\hline 71 & 1 & 6 & longear sunfish & Centrarchidae & 4.6 & 1.9 & 316 & 214 & \\
\hline 72 & 1 & 7 & longear sunfish & Centrarchidae & 5.0 & 2.3 & 316 & 214 & \\
\hline 73 & 1 & 8 & longear sunfish & Centrarchidae & 4.8 & 2 & 316 & 214 & \\
\hline 74 & 1 & 9 & longear sunfish & Centrarchidae & 6.2 & 3.8 & 316 & 214 & \\
\hline 75 & 1 & 10 & longear sunfish & Centrarchidae & 6.8 & 6 & 316 & 214 & \\
\hline 76 & 1 & 11 & longear sunfish & Centrarchidae & 5.1 & 2.4 & 316 & 214 & \\
\hline 77 & 1 & 12 & longear sunfish & Centrarchidae & 5.3 & 2.7 & 316 & 214 & \\
\hline 78 & 1 & 13 & longear sunfish & Centrarchidae & 5.0 & 3.7 & 316 & 214 & \\
\hline 79 & 1 & 14 & longear sunfish & Centrarchidae & 5.0 & 3.8 & 316 & 214 & \\
\hline 80 & 1 & 15 & longear sunfish & Centrarchidae & 3.9 & 1.8 & 316 & 214 & \\
\hline 81 & 1 & 16 & longear sunfish & Centrarchidae & 4.7 & 2 & 316 & 214 & \\
\hline 82 & 1 & 17 & longear sunfish & Centrarchidae & 4.8 & 2.2 & 316 & 214 & \\
\hline 83 & 1 & 1 & channel catfish & Ictaluridae & 27.9 & 212 & 318 & 164 & \\
\hline 84 & 1 & 2 & channel catfish & Ictaluridae & 18.4 & 79 & 318 & 164 & \\
\hline 85 & 1 & 1 & smallmouth bass & Centrarchidae & 9.6 & 11.5 & 319 & 328 & \\
\hline 86 & 1 & 2 & smallmouth bass & Centrarchidae & 14.8 & 40 & 319 & 328 & \\
\hline 87 & 1 & 3 & smallmouth bass & Centrarchidae & 17.0 & 89 & 319 & 328 & \\
\hline 88 & 1 & 4 & smallmouth bass & Centrarchidae & 7.1 & 5.3 & 319 & 328 & \\
\hline 89 & 1 & 5 & smallmouth bass & Centrarchidae & 6.9 & 4.9 & 319 & 328 & \\
\hline 90 & 1 & 1 & freshwater drum & Sciaenidae & 25.5 & 173 & 320 & 246 & \\
\hline 91 & 1 & 2 & freshwater drum & Sciaenidae & 23.8 & 147 & 320 & 246 & \\
\hline 92 & 1 & 1 & smallmouth buffalo & Catostomidae & 65.4 & 5678 & 321 & 1744 & \\
\hline
\end{tabular}




\begin{tabular}{|c|c|c|c|c|c|c|c|c|c|}
\hline \# & $\begin{array}{c}\text { Sub. } \\
\#\end{array}$ & No. & Common Name & Family & $\begin{array}{l}\text { Length } \\
(\mathrm{cm})\end{array}$ & $\begin{array}{l}\text { Weight } \\
\text { (g) }\end{array}$ & $\begin{array}{c}\text { Bag } \\
\#\end{array}$ & $\begin{array}{c}\text { Bag Wt } \\
(\mathrm{g})\end{array}$ & Notes \\
\hline 95 & 1 & 1 & white crappie & Centrarchidae & 28.0 & 328 & $\bar{k}$ & $\mathrm{k}$ & returned \\
\hline 96 & 2 & 1 . & carp & Cyprinidae & 42.3 & 952 & 325 & 498 & \\
\hline 97 & 2 & 2 & carp & Cyprinidae & 38.4 & 838 & 326 & 416 & \\
\hline 98 & 2 & 3 & carp & Cyprinidae & 46.1 & 1350 & 327 & 476 & \\
\hline 99 & 2 & 1 & river carpsucker & Catostomidae & 40.8 & 893 & 330 & 360 & \\
\hline 100 & 2 & 1 & golden redhorse & Catostomidae & 11.0 & 13.4 & 331 & 246 & \\
\hline 101 & 2 & 2 & golden redhorse & Catostomidae & 9.5 & 9.8 & 331 & 246 & \\
\hline 102 & 2 & 3 & golden redhorse & Catostomidae & 9.9 & 11.4 & 331 & 246 & \\
\hline 105 & 2 & 4 & golden redhorse & Catostomidae & 39.4 & 856 & 311 & 482 & \\
\hline 106 & 2 & 5 & golden redhorse & Catostomidae & 30.0 & 388 & 311 & 482 & \\
\hline 107 & 2 & 6 & golden redhorse & Catostomidae & 25.8 & 218 & 311 & 482 & \\
\hline 108 & 2 & 7 & golden redhorse & Catostomidae & 18.9 & 70.6 & 311 & 482 & \\
\hline 103 & 2 & 1 & black redhorse & Catostomidae & 30.4 & 392 & 331 & 246 & \\
\hline 104 & 2 & 1 & black buffalo & Catostomidae & 55.0 & 1958 & 322 & 918 & \\
\hline 109 & 2 & 1 & shorthead redhorse & Catostomidae & 37.8 & 620 & 317 & 280 & \\
\hline 110 & 2 & 1 & gizzard shad & Clupeidae & 19.4 & 74.6 & 304 & 394 & \\
\hline 111 & 2 & 2 & gizzard shad & Clupeidae & 20.1 & 80.1 & 304 & 394 & \\
\hline 112 & 2 & 3 & gizzard shad & Clupeidae & $1+.9$ & 34.8 & 304 & 394 & \\
\hline 113 & 2 & 4 & gizzard shad & Clupeidae & 18.2 & 86 & 304 & 394 & \\
\hline 114 & 2 & 5 & gizzard shad & Clupeidae & 20.5 & 93 & 304 & 394 & \\
\hline 115 & 2 & 6 & gizzard shad & Clupeidae & 10.6 & 12 & 328 & 402 & \\
\hline 116 & 2 & 7 & gizzard shad & Clupeidae & 13.1 & 19.3 & 328 & 402 & \\
\hline 117 & 2 & 8 & gizzard shad & Clupeidae & 10.7 & 13 & 328 & 402 & \\
\hline 118 & 2 & 9 & gizzard shad & Clupeidae & 13.6 & 21.7 & 328 & 402 & \\
\hline 119 & 2 & 10 & gizzard shad & Clupeidae & $1+1$ & 23.1 & 328 & 402 & \\
\hline 120 & 2 & 11 & gizzard shad & Clupeidae & 11.7 & 16.1 & 328 & 402 & \\
\hline 121 & 2 & 12 & gizzard shad & Clupeidae & 13.1 & 21 & 328 & 402 & \\
\hline 122 & 2 & 13 & gizzard shad & Clupeidae & 10.6 & 11.7 & 328 & 402 & \\
\hline 123 & 2 & 14 & gizzard shad & Clupeidae & 12.3 & 19.3 & 329 & 262 & \\
\hline 124 & 2 & 15 & gizzard shad & Clupeidae & 8.4 & 7.4 & 329 & 262 & \\
\hline 125 & 2 & 16 & gizzard shad & Clupeidae & 79 & 7.2 & 329 & 262 & \\
\hline 126 & 2 & 17 & gizzard shad & Clupeidae & 7.6 & 7.4 & 329 & 262 & \\
\hline 127 & 2 & 18 & gizzard shad & Clupeidae & 8.2 & 8 & 329 & 262 & \\
\hline 128 & 2 & 19 & gizzard shad & Clupeidax & $8+$ & 7.9 & 329 & 262 & \\
\hline 129 & 2 & 20 & gizzard shad & Clupeidac & 6.8 & 6.4 & 329 & 262 & \\
\hline 130 & 2 & 21 & gizzard shad & Clupeidae & 74 & 6.2 & 329 & 262 & \\
\hline 131 & 2 & 22 & gizzard shad & Clupeidae & 63 & 5 & 329 & 262 & \\
\hline 132 & 2 & 23 & gizzard shad & Clupeidae & 74 & 5.9 & 329 & 262 & \\
\hline 133 & 2 & 24 & gizzard shad & Clupeidac & 68 & 5.7 & 329 & 262 & \\
\hline 134 & 2 & 25 & gizzard shad & Clupeidac & 116 & 13.9 & 329 & 262 & \\
\hline 135 & 2 & 26 & gizzard shad & Clupeidac & 68 & 5.4 & 329 & 262 & \\
\hline 136 & 2 & 27 & gizzard shad & Clupeidac & 84 & 6.4 & 329 & 262 & \\
\hline 137 & 2 & 28 & gizzard shad & Clupeidac & 130 & 19.7 & 329 & 262 & \\
\hline 138 & 2 & 29 & gizzard shad & Clupeidac & 150 & 25.8 & 329 & 262 & \\
\hline 139 & 2 & 1 & bluegill & Centrarchudac & 75 & 8.2 & 332 & 360 & \\
\hline 140 & 2 & 2 & bluegill & Centrarchudae & 55 & 4.8 & 332 & 360 & \\
\hline 141 & 2 & 3 & bluegill & Centrarchidec & 73 & 7.5 & 332 & 360 & \\
\hline 142 & 2 & 4 & bluegill & Centrarchudac & 77 & 7.8 & 332 & 360 & \\
\hline
\end{tabular}




\begin{tabular}{|c|c|c|c|c|c|c|c|c|c|}
\hline$\#$ & $\begin{array}{c}\text { Sub. } \\
\#\end{array}$ & No. & Common Name & Family & $\begin{array}{l}\text { Length } \\
\text { (cm) }\end{array}$ & $\begin{array}{l}\text { Weight } \\
\text { (g) }\end{array}$ & $\begin{array}{c}\text { Bag } \\
\#\end{array}$ & $\begin{array}{c}\text { Bag Wt } \\
\text { (g) }\end{array}$ & Notes \\
\hline$\overline{143}$ & $\overline{2}$ & 5 & bluegiil & Centrarchidae & 5.1 & 3.4 & 332 & 360 & \\
\hline 144 & 2 & 6 & bluegill & Centrarchidae & 5.5 & 4 & 332 & 360 & \\
\hline 145 & 2 & 7 & bluegill & Centrarchidae & 8.5 & 13.8 & 332 & 360 & \\
\hline 146 & 2 & 1 & striped bass & Percichthyidae & 33 & 448 & $\mathbf{k}$ & $\mathbf{k}$ & returned \\
\hline 147 & 2 & 2 & striped bass & Percichthyidae & 22.5 & 116 & $\underline{\mathbf{k}}$ & $\mathbf{k}$ & returned \\
\hline 148 & 2 & 1 & black crappie & Centrarchidae & 23 & 156 & $\mathbf{k}$ & $\mathbf{k}$ & returned \\
\hline 149 & 2 & 1 & white crappie & Centrarchidae & 23 & 160 & $\mathbf{k}$ & $\mathbf{k}$ & returned \\
\hline 150 & 3 & 1 & carp & Cyprinidae & 76 & 7120 & 354 & 1174 & \\
\hline 151 & 3 & 2 & carp & Cyprinidae & 47.5 & 1462 & 340 & 402 & \\
\hline 152 & 3 & 3 & carp & Cyprinidae & 43.5 & 1220 & 341 & 322 & \\
\hline 153 & 3 & 4 & carp & Cyprinidae & 42.6 & 1108 & 342 & 324 & \\
\hline 154 & 3 & 1 & river carpsucker & Catostomidae & 43.1 & 1062 & 343 & 384 & \\
\hline 155 & 3 & 2 & river carpsucker & Catostomidae & 34.8 & 604 & 344 & 344 & \\
\hline 156 & 3 & 1 & black buffalo & Catostomidae & 59 & 3924 & 345 & 916 & \\
\hline 157 & 3 & 1 & freshwater drum & Sciaenidae & 26.9 & 250 & 346 & 224 & \\
\hline 158 & 3 & 2 & freshwater drum & Sciaenidae & 26.1 & 204 & 346 & 224 & \\
\hline 159 & 3 & 3 & freshwater drum & Sciaenidae & 22.8 & 321 & 346 & 224 & \\
\hline 160 & 3 & 1 & smallmouth bass & Centrarchidae & 19 & 100 & 319 & 328 & \\
\hline 161 & 3 & 2 & smallmouth bass & Centrarchidae & 13 & 28 & 319 & 328 & \\
\hline 162 & 3 & 3 & smallmouth bass & Centrarchidae & 12.2 & 22 & 319 & 328 & \\
\hline 163 & 3 & 4 & smallmouth bass & Centrarchidae & 12 & 18 & 319 & 328 & \\
\hline 164 & 3 & 5 & smallmouth bass & Centrarchidae & 10.3 & 10 & 319 & 328 & \\
\hline 165 & 3 & 6 & smallmouth bass & Centrarchidae & 9.1 & 10.1 & 319 & 328 & \\
\hline 166 & 3 & 7 & smallmouth bass & Centrarchidae & 8.9 & 8.6 & 319 & 328 & \\
\hline 167 & 3 & 8 & smallmouth bass & Centrarchidae & 8.4 & 7.9 & 319 & 328 & \\
\hline 168 & 3 & 9 & smallmouth bass & Centrarchidae & 9 & 9.1 & 319 & 328 & \\
\hline 169 & 3 & 10 & smallmouth bass & Centrarchidae & 8.4 & 6.8 & 319 & 328 & \\
\hline 170 & 3 & 1 & golden redhorse & Catostomidae & 30.3 & 300 & 350 & 202 & \\
\hline 171 & 3 & 1 & gizzard shad & Clupeidae & 27.3 & 208 & 348 & 394 & \\
\hline 172 & 3 & 2 & gizzard shad & Clupeidae & 22 & 112 & 348 & 394 & \\
\hline 173 & 3 & 3 & gizzard shad & Clupeidae & 27.3 & 186 & 348 & 394 & \\
\hline 174 & 3 & 4 & gizzard shad & Clupeidae & 24.7 & 166 & 348 & 394 & \\
\hline 175 & 3 & 5 & gizzard shad & Clupeidae & 27.3 & 208 & 349 & 556 & \\
\hline 176 & 3 & 6 & gizzard shad & Clupeidae & 27 & 208 & 349 & 556 & \\
\hline 177 & 3 & 7 & gizzard shad & Clupeidae & 21.9 & 106 & 349 & 556 & \\
\hline 178 & 3 & 8 & gizzard shad & Clupeidae & 23.9 & 134 & 349 & 556 & \\
\hline 179 & 3 & 9 & gizzard shad & Clupeidae & 24.5 & 152 & 349 & 556 & \\
\hline 180 & 3 & 10 & gizzard shad & Clupeidae & 25.4 & 168 & 349 & 556 & \\
\hline 181 & 3 & 11 & gizzard shad & Clupeidae & 24.8 & 158 & 351 & 390 & \\
\hline 182 & 3 & 12 & gizzard shad & Clupeidae & 25.3 & 168 & 351 & 390 & \\
\hline 183 & 3 & 13 & gizzard shad & Clupeidae & 21.4 & 94 & 351 & 390 & \\
\hline 184 & 3 & 14 & gizzard shad & Clupeidae & 21.8 & 98 & 351 & 390 & \\
\hline 185 & 3 & 15 & gizzard shad & Clupeidae & 21.2 & 94 & 351 & 390 & \\
\hline 186 & 3 & 16 & gizzard shad & Clupeidae & 17.4 & 50 & 351 & 390 & \\
\hline 187 & 3 & 17 & gizzard shad & Clupeidae & 17.8 & 52.3 & 352 & 290 & \\
\hline 188 & 3 & 18 & gizzard shad & Clupeidae & 18.6 & 62.8 & 352 & 290 & \\
\hline 189 & 3 & 19 & gizzard shad & Clupeidae & 18.5 & 61 & 352 & 290 & \\
\hline 190 & 3 & 20 & gizzard shad & Clupeidae & 18.9 & 64.4 & 352 & 290 & \\
\hline 191 & 3 & 21 & gizzard shad & Clupeidae & 17.1 & 49.2 & 352 & 290 & \\
\hline
\end{tabular}




\begin{tabular}{|c|c|c|c|c|c|c|c|c|c|}
\hline \# & $\begin{array}{c}\text { Sub. } \\
\#\end{array}$ & No. & Common Name & Family & $\begin{array}{l}\text { Length } \\
(\mathrm{cm})\end{array}$ & $\begin{array}{c}\text { Weight } \\
\text { (g) }\end{array}$ & $\begin{array}{c}\text { Bag } \\
\#\end{array}$ & $\begin{array}{c}\text { Bag Wt } \\
\text { (g) }\end{array}$ & Notes \\
\hline 192 & 3 & 22 & gizzard shad & Clupeidae & 17.6 & 55.1 & 352 & 290 & \\
\hline 193 & 3 & 23 & gizzard shad & Clupeidae & 19.6 & 77.2 & 352 & 290 & \\
\hline 194 & 3 & 24 & gizzard shad & Clupeidae & 18.8 & 67.3 & 352 & 290 & \\
\hline 195 & 3 & 25 & gizzard shad & Clupeidae & 18 & 56.1 & 353 & 314 & \\
\hline 196 & 3 & 26 & gizzard shad & Clupeidae & 19.7 & 70.1 & 353 & 314 & \\
\hline 197 & 3 & 27 & gizzard shad & Clupeidae & 18.6 & 65.1 & 353 & 314 & \\
\hline 198 & 3 & 28 & gizzard shad & Clupeidae & 20.2 & 80.3 & 353 & 314 & \\
\hline 199 & 3 & 29 & gizzard shad & Clupeidae & 21.1 & 90 & 353 & 314 & \\
\hline 200 & 3 & 30 & gizzard shad & Clupeidae & 17.7 & 54 & 353 & 314 & \\
\hline 201 & 3 & 31 & gizzard shad & Clupeidae & 19 & 70 & 353 & 314 & \\
\hline 202 & 3 & 32 & gizzard shad & Clupeidae & 17.3 & 47 & 353 & 314 & \\
\hline 203 & 3 & 33 & gizzard shad & Clupeidae & 10.9 & 12 & 355 & 250 & \\
\hline 204 & 3 & 34 & gizzard shad & Clupeidae & 10.5 & 11.4 & 355 & 250 & \\
\hline 205 & 3 & 35 & gizzard shad & Clupeidae & 14 & 23.3 & 355 & 250 & \\
\hline 206 & 3 & 36 & gizzard shad & Clupeidae & 10.2 & 10.1 & 355 & 250 & \\
\hline 207 & 3 & 37 & gizzard shad & Clupeidae & 11.8 & 16.2 & 355 & 250 & \\
\hline 208 & 3 & 38 & gizzard shad & Clupeidae & 18.6 & 64 & 355 & 250 & \\
\hline 209 & 3 . & 39 & gizzard shad & Clupeidae & 10.9 & 12.2 & 355 & 250 & \\
\hline 210 & 3 & 40 & gizzard shad & Clupeidae & 11.2 & 14.4 & 355 & 250 & \\
\hline 211 & 3 & 41 & gizzard shad & Clupeidae & 10.5 & 11.9 & 355 & 250 & \\
\hline 212 & 3 & 42 & gizzard shad & Clupeidae & 13.5 & 23.2 & 355 & 250 & \\
\hline 213 & 3 & 43 & gizzard shad & Clupeidae & 11.9 & 14.6 & 355 & 250 & \\
\hline 214 & 3 & 44 & gizzard shad & Clupeidae & 10 & 10.1 & 355 & 250 & \\
\hline 215 & 3 & 45 & gizzard shad & Clupeidae & 9.1 & 6.9 & 355 & 250 & \\
\hline 216 & 3 & 46 & gizzard shad & Clupeidae & 11.5 & 13.6 & 355 & 250 & \\
\hline 217 & 3 & 47 & gizzard shad & Clupeidae & 11.8 & 15.1 & 355 & 250 & \\
\hline 218 & 3. & 48 & gizzard shad & Clupeidae & 10 & 9.3 & 355 & 250 & \\
\hline 219 & 3 & 49 & gizzard shad & Clupeidae & 10.1 & 10.5 & 355 & 250 & \\
\hline 220 & 3 & 50 & gizzard shad & Clupeidae & 11.1 & 14.5 & 355 & 250 & \\
\hline 221 & 3 & 51 & gizzard shad & Clupeidae & 10.1 & 9.8 & 355 & 250 & \\
\hline 222 & 3 & 52 & gizzard shad & Clupeidae & 9.2 & 7.2 & 355 & 250 & \\
\hline 223 & 3 & 53 & gizzard shad & Clupeidae & 9.5 & 9 & 355 & 250 & \\
\hline 224 & 3 & 1 & bluegill & Centrarchidae & 15.3 & 80 & 356 & 268 & \\
\hline 225 & 3 & 2 & bluegill & Centrarchidae & 14.6 & 74 & 356 & 268 & \\
\hline 226 & 3 & 3 & bluegill & Centrarchidae & 13.2 & 46 & 356 & 268 & \\
\hline 227 & 3 & 4 & bluegill & Centrarchidae & 13.5 & 52.4 & 356 & 268 & \\
\hline 228 & 3 & 5 & bluegill & Centrarchidae & 14 & 61.9 & 356 & 268 & \\
\hline 229 & 3 & 6 & bluegill & Centrarchidae & 13.9 & 58.3 & 356 & 268 & \\
\hline 230 & 3 & 7 & bluegill & Centrarchidae & 13.4 & 58.6 & 356 & 268 & \\
\hline 231 & 3 & 8 & bluegill & Centrarchidae & 13.5 & 51.4 & 356 & 268 & \\
\hline 232 & 3 & 9 & bluegill & Centrarchidae & 12.6 & 44 & 332 & 306 & \\
\hline 233 & 3 & 10 & bluegill & Centrarchidae & 11 & 27.8 & 332 & 306 & \\
\hline 234 & 3 & 11 & bluegill & Centrarchidae & 9.4 & 17.8 & 332 & 306 & \\
\hline 235 & 3 & 12 & bluegill & Centrarchidae & 10 & 19.8 & 332 & 306 & \\
\hline 236 & 3 & 13 & bluegill & Centrarchidae & 8.6 & 13.8 & 332 & 306 & \\
\hline 237 & 3 & 14 & bluegill & Centrarchidae & 10 & 20.6 & 332 & 306 & \\
\hline 238 & 3 & 15 & bluegill & Centrarchidae & 8.1 & 9 & 332 & 306 & \\
\hline 239 & 3 & 16 & bluegill & Centrarchidae & 7.5 & 7.4 & 332 & 306 & \\
\hline 240 & 3 & 17 & bluegill & Centrarchidae & 6.1 & 4 & 332 & 306 & \\
\hline
\end{tabular}




\begin{tabular}{|c|c|c|c|c|c|c|c|c|c|}
\hline$\#$ & $\begin{array}{c}\text { Sub. } \\
\#\end{array}$ & No. & Common Name & Family & $\begin{array}{l}\text { Length } \\
(\mathrm{cm})\end{array}$ & $\begin{array}{l}\text { Weight } \\
\text { (g) }\end{array}$ & $\begin{array}{c}\text { Bag } \\
\#\end{array}$ & $\begin{array}{c}\text { Bag Wt } \\
\text { (g) }\end{array}$ & Notes \\
\hline 241 & $\overline{3}$ & $\overline{18}$ & bluegill & Centrarchidae & 4.6 & 1.8 & 332 & 306 & \\
\hline 242 & 3 & 19 & bluegill & Centrarchidae & 6.5 & 5.1 & 332 & 306 & \\
\hline 243 & 3 & 20 & bluegill & Centrarchidae & 6.1 & 3.7 & 332 & 306 & \\
\hline 244 & 3 & 21 & bluegill & Centrarchidae & 7.3 & 7.4 & 332 & 306 & \\
\hline 245 & 3 & 22 & bluegill & Centrarchidae & 7.6 & 8.1 & 332 & 306 & \\
\hline 246 & 3 & 23 & bluegill & Centrarchidae & 6.4 & 4.6 & 332 & 306 & \\
\hline 247 & 3 & 24 & bluegill & Centrarchidae & 7.3 & 7.2 & 332 & 306 & \\
\hline 248 & 3 & 25 & bluegill & Centrarchidae & 6.7 & 5 & 332 & 306 & \\
\hline 249 & 3 & 26 & bluegill & Centrarchidae & 6.7 & 6 & 332 & 306 & \\
\hline 250 & 3 & 27 & bluegill & Centrarchidae & 6 & 3.5 & 332 & 306 & \\
\hline 251 & 3 & 28 & bluegill & Centrarchidae & 7.1 & 6.9 & 332 & 306 & \\
\hline 252 & 3 & 29 & bluegill & Centrarchidae & $\overline{7.5}$ & 8 & 332 & 306 & \\
\hline 253 & 3 & 30 & bluegill & Centrarchidae & 4.7 & 2 & 332 & 306 & \\
\hline 254 & 3 & 31 & bluegill & Centrarchidae & 6.5 & $\overline{5.5}$ & 332 & 306 & \\
\hline 255 & 3 & 32 & bluegill & Centrarchidae & 7.2 & $\overline{7.2}$ & 332 & 306 & \\
\hline 256 & 3 & 33 & bluegill & Centrarchidae & 6.5 & 5 & 332 & 306 & \\
\hline 257 & 3 & 34 & bluegill & Centrarchidae & 6.6 & 5 & 332 & 306 & \\
\hline 258 & 3 & 35 & bluegill & Centrarchidae & 6.2 & 3.9 & 332 & 306 & \\
\hline 259 & 3 & 1 & longear sunfish & Centrarchidae & 14.3 & 67.1 & 358 & 334 & \\
\hline 260 & 3 & 2 & longear sunfish & Centrarchidae & 14.6 & 78.3 & 358 & 334 & \\
\hline 261 & 3 & 3 & longear sunfish & Centrarchidae & 12 & 39.7 & 358 & 334 & \\
\hline 262 & 3 & 4 & longear sunfish & Centrarchidae & 10.4 & 26 & 358 & 334 & \\
\hline 263 & 3 & 5 & longear sunfish & Centrarchidae & 9.7 & 21.1 & 358 & 334 & \\
\hline 264 & 3 & 6 & longear sunfish & Centrarchidae & 10.5 & 27.3 & 358 & 334 & \\
\hline 265 & 3 & 7 & longear sunfish & Centrarchidae & 9.7 & 17.4 & 358 & 334 & \\
\hline 266 & 3 & 8 & longear sunfish & Centrarchidae & 10 & 20.8 & 358 & 334 & \\
\hline 267 & 3 & 9 & longear sunfish & Centrarchidae & 8.9 & 14 & 358 & 334 & \\
\hline 268 & 3 & 10 & longear sunfish & Centrarchidae & 10 & 21.7 & 358 & 334 & \\
\hline 269 & 3 & 11 & longear sunfish & Centrarchidae & 11.8 & 33.3 & 358 & 334 & \\
\hline 270 & 3 & 12 & longear sunfish & Centrarchidae & 9.3 & 15.6 & 358 & 334 & \\
\hline 271 & 3 & 13 & longear sunfish & Centrarchidae & 9.1 & 13 & 358 & 334 & \\
\hline 272 & 3 & 14 & longear sunfish & Centrarchidac & 8.4 & 12 & 358 & 334 & \\
\hline 273 & 3 & 15 & longear sunfish & Centrarchidae & 5.5 & 3.7 & 358 & 334 & \\
\hline 274 & 3 & 16 & longear sunfish & Centrarchidac & 6 & 4 & 358 & 334 & \\
\hline 275 & 3 & 17 & longear sunfish & Centrarchidac & 57 & 3.8 & 358 & 334 & \\
\hline 276 & 3 & 18 & longear sunfish & Centrarchidae & $6+$ & 5.4 & 358 & 334 & \\
\hline 277 & 3 & 19 & longear sunfish & Centrarchidoe & 65 & 6.2 & 358 & 334 & \\
\hline 278 & 3 & 20 & longear sunfish & Centrarchidee & 5.9 & 3.8 & 358 & 334 & \\
\hline 279 & 3 & 21 & longear sunfish & Centrarchidece & 58 & 3.9 & 358 & 334 & \\
\hline 280 & 3 & 1 & striped bass & Percichthride & 255 & 173 & $\mathbf{k}$ & $\mathbf{k}$ & returned \\
\hline 281 & 3 & 1 & sauger & Percidae & 26 & 132 & $\mathbf{k}$ & $\mathbf{k}$ & returned \\
\hline 282 & 3 & 2 & sauger & Percidae & 255 & 122 & $\mathbf{k}$ & $\mathbf{k}$ & returned \\
\hline 283 & 3 & 3 & sauger & Percidae & 27 & 148 & $\mathbf{k}$ & $\mathbf{k}$ & returned \\
\hline 284 & 4 & 1 & bluegill & Centrarchudxe & 62 & 4.7 & 332 & 306 & \\
\hline 285 & 4 & 2 & bluegill & Centrarchidoc & 76 & 9 & 332 & 306 & \\
\hline 286 & 4 & 3 & bluegill & Centrarchide & 63 & 4.9 & 332 & 306 & \\
\hline 287 & 4 & 1 & longear sunfish & Centrarchide & 113 & 33.1 & 358 & 334 & \\
\hline 288 & 4 & 2 & longear sunfish & Centrarchide & 97 & 19.6 & 358 & 334 & \\
\hline 289 & 4 & 3 & longear sunfish & Centrarchidoe & 91 & 18.1 & 358 & 334 & \\
\hline
\end{tabular}




\begin{tabular}{|c|c|c|c|c|c|c|c|c|c|}
\hline \# & $\begin{array}{c}\text { Sub. } \\
\#\end{array}$ & No. & Common Name & Family & $\begin{array}{l}\text { Length } \\
(\mathrm{cm})\end{array}$ & $\begin{array}{l}\text { Weight } \\
\text { (g) }\end{array}$ & $\begin{array}{c}\text { Bag } \\
\#\end{array}$ & $\begin{array}{c}\text { Bag Wt } \\
\text { (g) }\end{array}$ & Notes \\
\hline 290 & 4 & $\overline{4}$ & longear sunfish & Centrarchidae & 6.6 & 6.7 & 358 & 334 & \\
\hline 291 & 4 & 5 & longear sunfish & Centrarchidae & 6.6 & 6.6 & 358 & 334 & \\
\hline 292 & 4 & 6 & longear sunfish & Centrarchidae & 6.5 & 5.5 & 358 & 334 & \\
\hline 293 & 4 & 7 & longear sunfish & Centrarchidae & 6.2 & 5.3 & 358 & 334 & \\
\hline 294 & 4 & 1 & gizzard shad & Clupeidae & 29.3 & 258 & 359 & 404 & \\
\hline 295 & 4 & 2 & gizzard shad & Clupeidae & 24.6 & 156 & 359 & 404 & \\
\hline 296 & 4 & 3 & gizzard shad & Clupeidae & 25.6 & 186 & 359 & 404 & \\
\hline 297 & 4 & 4 & gizzard shad & Clupeidae & 24.1 & 134 & 359 & 404 & \\
\hline 298 & 4 & 5 & gizzard shad & Clupeidae & 22.8 & 122 & 360 & 282 & \\
\hline 299 & 4 & 6 & gizzard shad & Clupeidae & 20 & 76 & 360 & 282 & \\
\hline 300 & 4 & 7 & gizzard shad & Clupeidae & 20.5 & 82 & 360 & 282 & \\
\hline 301 & 4 & 8 & gizzard shad & Clupeidae & 19.5 & 74 & 360 & 282 & \\
\hline 302 & 4 & 9 & gizzard shad & Clupeidae & 17.5 & 60 & 360 & 282 & \\
\hline 303 & 4 & 10 & gizzard shad & Clupeidae & 18.6 & 58 & 360 & 282 & \\
\hline 304 & 4 & 11 & gizzard shad & Clupeidae & 14 & 26.4 & 360 & 282 & \\
\hline 305 & 4 & 12 & gizzard shad & Clupeidae & 14.2 & 24.3 & 355 & 250 & \\
\hline 306 & 4 & 13 & gizzard shad & Clupeidae & 13.6 & 23.2 & 355 & 250 & \\
\hline 307 & 4 & 14 & gizzard shad & Clupeidae & 12.5 & 19.7 & 355 & 250 & \\
\hline 308 & 4 & 15 & gizzard shad & Clupeidae & 12.4 & 17.9 & 355 & 250 & \\
\hline 309 & 4 & 16 & gizzard shad & Clupeidae & 11 & 12.7 & 355 & 250 & \\
\hline 310 & 4 & 17 & gizzard shad & Clupeidae & 11.1 & 13.4 & 355 & 250 & \\
\hline 311 & 4 & 18 & gizzard shad & Clupeidae & 11.3 & 14.6 & 355 & 250 & \\
\hline 312 & 4 & 19 & gizzard shad & Clupeidae & 11.1 & 12.9 & 361 & 282 & \\
\hline 313 & 4 & 20 & gizzard shad & Clupeidae & 10.8 & 12.4 & 361 & 282 & \\
\hline 314 & 4 & 21 & gizzard shad & Clupeidae & 10.8 & 12.1 & 361 & 282 & \\
\hline 315 & 4 & 22 & gizzard shad & Clupeidae & 12.2 & 18.5 & 361 & 282 & \\
\hline 316 & 4 & 23 & gizzard shad & Clupeidae & 11.2 & 13.8 & 361 & 282 & \\
\hline 317 & 4 & 24 & gizzard shad & Clupeidae & 11.5 & 15.1 & 361 & 282 & \\
\hline 318 & 4 & 25 & gizzard shad & Clupeidae & 10.4 & 12.2 & 361 & 282 & \\
\hline 319 & 4 & 26 & gizzard shad & Clupeidae & 10.3 & 11.4 & 361 & 282 & \\
\hline 320 & 4 & 27 & gizzard shad & Clupeidae & 10.2 & 10 & 361 & 282 & \\
\hline 321 & 4 & 28 & gizzard shad & Clupeidae & 9.6 & 9.1 & 361 & 282 & \\
\hline 322 & 4 & 29 & gizzard shad & Clupeidae & 11 & 12.8 & 361 & 282 & \\
\hline 323 & 4 & 30 & gizzard shad & Clupeidae & 9.8 & 9.4 & 361 & 282 & \\
\hline 324 & 4 & 31 & gizzard shad & Clupeidae & 10.5 & 11.1 & 361 & 282 & \\
\hline 325 & 4 & 32 & gizzard shad & Clupeidae & 9.4 & 8.9 & 361 & 282 & \\
\hline 326 & 4 & 33 & gizzard shad & Clupeidae & 11 & 13.7 & 361 & 282 & \\
\hline 327 & 4 & 34 & gizzard shad & Clupeidae & 10.6 & 11.8 & 361 & 282 & \\
\hline 328 & 4 & 35 & gizzard shad & Clupeidae & 10.8 & 12.6 & 361 & 282 & \\
\hline 329 & 4 & 36 & gizzard shad & Clupeidae & 10.1 & 10.6 & 361 & 282 & \\
\hline 330 & 4 & 37 & gizzard shad & Clupeidae & 10.8 & 12 & 361 & 282 & \\
\hline 331 & 4 & 38 & gizzard shad & Clupeidae & 11.1 & 13.8 & 361 & 282 & \\
\hline 332 & 4 & 39 & gizzard shad & Clupeidae & 9.2 & 7.9 & 361 & 282 & \\
\hline 333 & 4 & 40 & gizzard shad & Clupeidae & 9.7 & 9.4 & 361 & 282 & \\
\hline 334 & 4 & 41 & gizzard shad & Clupeidae & 10 & 10.4 & 361 & 282 & \\
\hline 335 & 4 & 42 & gizzard shad & Clupeidae & 10.7 & 12.7 & 361 & 282 & \\
\hline 336 & 4 & 43 & gizzard shad & Clupeidae & 11.2 & 14.2 & 361 & 282 & \\
\hline 337 & 4 & 44 & gizzard shad & Clupeidae & 10.1 & 10.3 & 361 & 282 & \\
\hline 338 & 4 & 45 & gizzard shad & Clupeidae & 10.5 & 12 & 361 & 282 & \\
\hline
\end{tabular}




\begin{tabular}{|c|c|c|c|c|c|c|c|c|c|}
\hline$\#$ & $\begin{array}{c}\text { Sub. } \\
\#\end{array}$ & No. & Common Name & Family & $\begin{array}{l}\text { Length } \\
\text { (cm) }\end{array}$ & $\begin{array}{l}\text { Weight } \\
\text { (g) }\end{array}$ & $\begin{array}{c}\text { Bag } \\
\#\end{array}$ & $\begin{array}{c}\text { Bag Wt } \\
\text { (g) }\end{array}$ & Notes \\
\hline 339 & $\overline{4}$ & $\overline{46}$ & gizzard shad & TClupeidae & 111.5 & 14.8 & 361 & 282 & \\
\hline 340 & 4 & 47 & gizzard shad & Clupeidae & 10.4 & 11.8 & 361 & 282 & \\
\hline 341 & 4 & 48 & gizzard shad & Clupeidae & 9.9 & 9 & 361 & 282 & \\
\hline 342 & 4 & 49 & gizzard shad & Clupeidae & 11.2 & 14 & 361 & 282 & \\
\hline 343 & 4 & 50 & gizzard shad & Clupeidae & 9.5 & 8.6 & 361 & 282 & \\
\hline 344 & 4 & 51 & gizzard shad & Clupeidae & 11.2 & 13.3 & 361 & 282 & \\
\hline 345 & 4 & 52 & gizzard shad & Clupeidae & 10.2 & 11.5 & 361 & 282 & \\
\hline 346 & 4 & 53 & gizzard shad & Clupeidae & 11 & 12.8 & 361 & 282 & \\
\hline 347 & 4 & 54 & gizzard shad & Clupeidae & 10.4 & 10.8 & 361 & 282 & \\
\hline 348 & 4 & 55 & gizzard shad & Clupeidae & 10.7 & 12 & 361 & 282 & \\
\hline 349 & 4 & 56 & gizzard shad & Clupeidae & 10.5 & 12.3 & 361 & 282 & \\
\hline 350 & 4 & 57 & gizzard shad & Clupeidae & 10.8 & 12.6 & 361 & 282 & \\
\hline 351 & 4 & 1 & golden redhorse & Catostomidae & 28.4 & 290 & 362 & 460 & \\
\hline 352 & 4 & 2 & golden redhorse & Catostomidae & 17.9 & 66 & 362 & 460 & \\
\hline 353 & 4 & 1 & river carpsucker & Catostomidae & +0.2 & 812 & 362 & 460 & \\
\hline 354 & 4 & 1 & sauger & Perdidae & 24.8 & 118 & $\mathbf{k}$ & $k$ & UC collection \\
\hline 355 & 4 & 2 & sauger & Perdidae & 26 & 124 & $\mathbf{k}$ & $\mathbf{k}$ & returned \\
\hline 356 & 4 & 3 & sauger & Perdidae & 27.7 & 158 & $\mathbf{k}$ & k & returned \\
\hline 357 & 4 & 1 & freshwater drum & Sciaenidae & 22.2 & 152 & 347 & 228 & \\
\hline 358 & 4 & 1 & smallmouth bass & Centrarchidae & 12.3 & 25.5 & 347 & 228 & \\
\hline 359 & 4 & 2 & smallmouth bass & Centrarchidae & 11.6 & 20.5 & 347 & 228 & \\
\hline 360 & 4 & 3 & smallmouth bass & Centrarchidae & 9 & 9.2 & 347 & 228 & \\
\hline 361 & 4 & 1 & striped bass & Percichthvidae & 16.8 & 54.4 & 347 & 228 & \\
\hline 362 & 4 & 2 & striped bass & Percichthvidae & 15.8 & 46.5 & 347 & 228 & \\
\hline 363 & 4 & 3 & striped bass & Percichthyidxe & 12.8 & 25.9 & 347 & 228 & \\
\hline 364 & 4 & 4 & striped bass & Percichthvidae & 16.8 & 54.8 & 347 & 228 & \\
\hline 365 & 4 & 5 & striped bass & Percichthvidae & 15.3 & 45.1 & 347 & 228 & \\
\hline 366 & 4 & 6 & striped bass & Percichthridae & 21.2 & 110 & $\mathbf{k}$ & $\mathbf{k}$ & returned \\
\hline 367 & 4 & 7 & striped bass & Percichthvidae & 24.9 & 194 & $\mathbf{k}$ & $\mathbf{k}$ & returned \\
\hline 368 & 4 & 8 & striped bass & Percichthvidae & 26.3 & 236 & $\mathbf{k}$ & $\mathbf{k}$ & returned \\
\hline 369 & 4 & 9 & striped bass & Percichthvidae & 20.7 & 98 & $\mathbf{k}$ & $\underline{\mathbf{k}}$ & returned \\
\hline 370 & 4 & 10 & striped bass & Percichthidae & 19.2 & 84 & $\mathbf{k}$ & $\mathbf{k}$ & returned \\
\hline 371 & 4 & 11 & striped bass & Percichthidac & 196 & 88 & $\mathbf{k}$ & $\mathbf{k}$ & returned \\
\hline
\end{tabular}

